Portland State University

PDXScholar

7-23-1973

\title{
Contributions of Peter Pallas to Science and Exploration in Russia
}

Robert C. Parker

Portland State University

Follow this and additional works at: https://pdxscholar.library.pdx.edu/open_access_etds

Part of the European History Commons, and the History of Science, Technology, and Medicine Commons

Let us know how access to this document benefits you.

\section{Recommended Citation}

Parker, Robert C., "Contributions of Peter Pallas to Science and Exploration in Russia" (1973).

Dissertations and Theses. Paper 1699.

https://doi.org/10.15760/etd.1698

This Thesis is brought to you for free and open access. It has been accepted for inclusion in Dissertations and Theses by an authorized administrator of PDXScholar. Please contact us if we can make this document more accessible: pdxscholar@pdx.edu. 
AN ABSTRACT OF THE THESIS OF Robert $c$. Parker for the Master of Arts in History presented July 23, 1973.

Title: Contributions of Peter: Pallas to Science and Exploration in Russia.

APPROVED BY MEMBERS OF THE THESIS COMMITTEE:

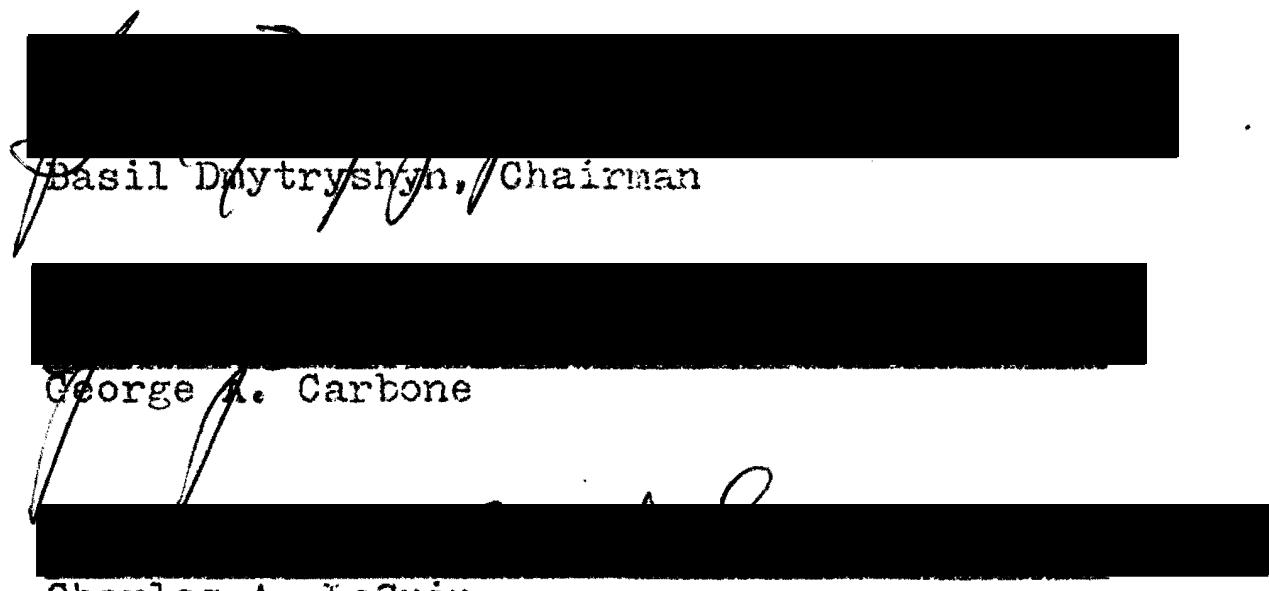

$$
\text { Charles A. LeGuin }
$$

This thesis presents an account of a prominent eighteenth-century European naturalist, Peter Pailas (1.7411811), in the setting to which he contributed his scientific talents-mthe St. Petersburg Academy of Sciences. A complete outzine of Palias life is presented for purposes or corttinuity, but the heario of the thesis is presented in chapters four and five, which combined, reiate the major features of Pallas career in Russia. Phese two chapters are set against pertinent background material, most of which is involved with the institution itself which supported pallas. The st. 
Petersburg Academy of sciences is surveyed in its origin and development in the eighteenth century and material is presented which will outline the ups and downs of the devel.* opment of academic life in Russia as well as the general milieu in which Pallas fitted. This milieu, it has been concluded, was one of lively and relatively unfettered advance in the development of science in Russia, to which Pallas contributed a great deal of stimulus by way of his widely known and respected accomplishments.

The focal point of pallas' career is represented by his Siberian expedition of 1768-1774, a momentous six-year scientific enterprise to which a central part of the research has been directed. The account of the Pallas Expedition presented here is entirely original, utilizing chiefly his own travel account and the Proceedings (Protokoly) of the Academy, from which source, in the absence of archival materials, can be gained the general content of paljas' communications to the Academy during his absence. To add perspective, the Pallas Expedition has been set against the historical and contemporary background of Russian scientific exploration in the eighteenth century. An appendix has also been included which lists the Russian-sponsored eighteonthcentury scientific expeditions.

The follow-up to Pallas' expedition--the remainder of his career in St. Petersburg--is equaliy a central part of the study. As an academician in st. Petersburg from 1774 to 1793. Pailas was a luminary of European natural science as 
well as a pilla: of scientific achievement in Russia. In historical terms and seen against the background of the Academy of which he was a part, Pallas' scholarly contributions in Russia have been outlined, most of w'.ich can be explained as a consequence of his expedition. A wide selection. of available secondary material has been utilized to explain Pallas' academic career, supplemented by some original research (chiefly from the Academy Proceedings) and the opportunity I have had to see and scan most of his major publica.tions pertaining to zoology and botany, the major fields to which he contributed.

Although of German background, Pallas spent most of his adult life in Russia (1767-1810). His career there forms one of the highlights of forejgn scientific and expeditionary achievement during the century that Russia relied almost exclusively on foreigners to establish the serious beginnings: of both. His contributions--expeditionary and academically in the realm of biology--for obvious reasons are more closely connected to the Russian arena; perhaps for that reason he has failed to attract deserved notice alongside the eighteenthcentury European naturalists who are now more popularly knowm. This thesis attempts no more than to account historically for the career of Peter Simon Pallas in Russia and to present his remarkable accomplishments.

A categorized, partially annotated bibliography is appended, preceded by a bibliographic explanation. 
CONTRIBUTIONS OF PETER PAIIAS TO SCIENCE

AND EXPLORATION IN RUSSIA

\author{
by \\ ROBERT C. PARKER
}

A thesis submitted in partial sulfillment of the requirements for the degree of

\author{
MASTER OF ARTS \\ in \\ HISTORY
}

Portland State University

1973 
TO THE OFFICE OF GRADUATE STUDIES AND RESEARCH:

The members of the Committee approve the thesis of Robert C. Parker presented July 2.3. 1973.

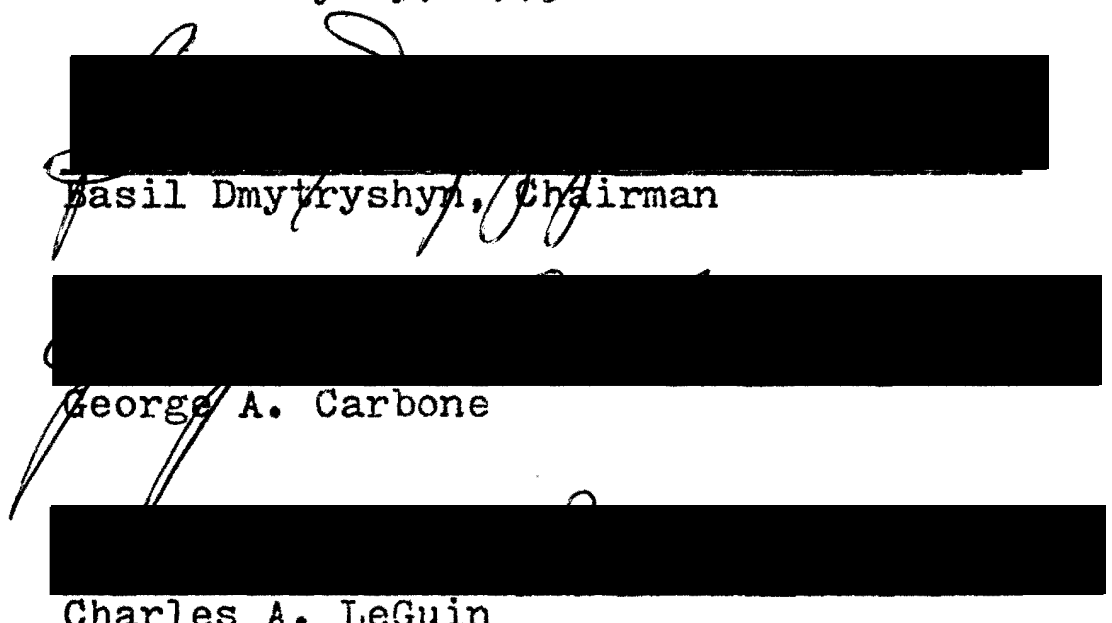

APPROVED :

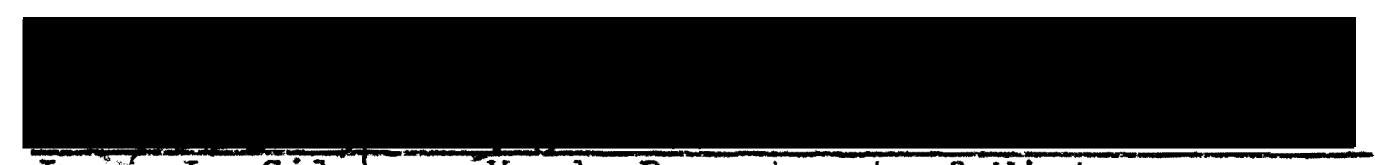

Jesse L. GjImbre, Head, Department of History

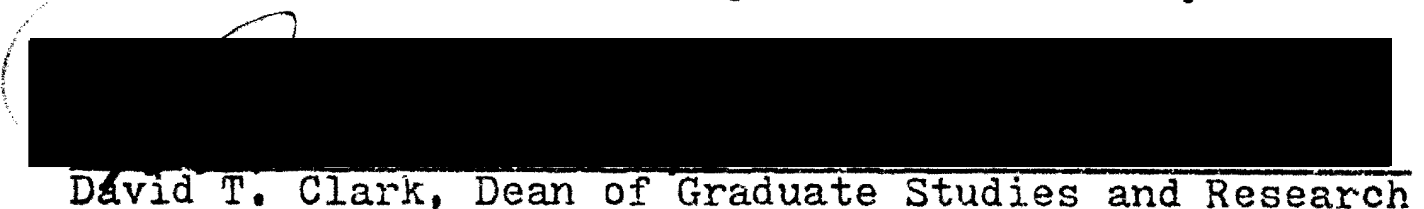

July 25,1973 


\section{ACKNOWLEDGMENTS}

This thesis owes its origin to Professor Basil Dmytryshyn, whose teaching and image of scholarship it has been my substantial fortune to krow. To him a large debt of thanks is owed for willing and critical counsel the qualities of which are many, but the chief quality of which is an expert vision of what remains to be done. In presenting the central figure of the thesis in the way that has been done I have followed, to whatever outcome, my own lights.

As very pertinent to the outcome of this thesis it should also be acknowledged that E.A.P. Crownhart-Vaughan of the Oregon Historical Society on several occasions has graciously taken the time to point out and provide helpful materials from the Society's collection which I otherwise could easily have missed.

I appreciate also the efficiency with which the interlibrary loan service has handled numerous requests. 
TABLE OF CONTENTS

PAGE

ACKNOWLEDGMENTS . • • • . . . . . . • •

PART ONE: INTRODUCTORY AND BACKGROUND

CHAPTER

I INTRODUCTION. • • • • • . • •

II THE ST. PETERSBURG ACADEMY AND ITS RECORD OF SCIENCE AND EXPIORATION

IN THE EIGHTEENTH CENTURY . . . . . •

PART TWO: PALLAS' EXPEDITIONARY AND ACADEMIC CAREER IN RUSSIA

III PALIAS: EARIY YEARS. . . . . . . 52

IV THE PAIIAS EXPEDITION ....... 62

$\checkmark$ PALLAS AS ACADEMICIAN IN. ST, PETERSBURG, $1774-1793$....... . 116

VI LATER YEARS: SECOND EXPEDITION AND RESIDENCE IN THE CRIMEA . . . . . . 167

A Note on Pallas.

Zoographia Rosso-Asiatica. . . . 


\section{LIST OF FIGURES}

FIGURE

PAGE

I Map Showing General Itinerary of the

Pallas Expeaition . . . . . . . endpaper 


\section{PART ONE}

INTRODUCTORY AND BACKGROUND 


\section{CHAPTER I}

\section{INTRODUCTION}

As a natural scientist in the eighteenth century Peter Pallas (1741-1811) was as much revered as his two now more popularly known contemporaries in the same field, Carl Linnaeus and George Louis Buffon, both of whom, born in 1707, represented the older generation to Pallas. His work has faded from the view of subsequent generations largely due to the fact that he spent the greater part of his life working as a member of the St. Petersburg Academy of Sciences, in a country whose internal achievements have rarely been taken into account in discussions of general European developments. Among the contemporary men of learning, however, the scientific work carried on in the st. Petersburg Academy by its outstanding members was widely known. In his lifetime pallas was honored by being elected to every major scientific academy in Europe, and following his death, lengthy and glowing eulogies evaluating his work were read before the Berlin Academy (by Karl Rudolphi) and the Paris Academy (by Georges Cuvier). Pallas' work even reached America, where in 1791 he was elected an honorary member of the young republic's Philosophical Society of Philadelphia. ${ }^{1}$

${ }^{1}$ N.N. Bolkhovitinov, Stanovlenie Russko-Amerikanskikh 
A work on Pallas could be undertaken from two principal directions: either in terms of his achievements and the advancements he heralded in the natural sciences (primarily zoology) in a European context, or more in terms of his life and work in the milieu of academic and expeditionary activity in Russia in the eighteenth century since most of his mature life was spent there $(1767-1810)$ and since for the dawning age of Russian science in the eighteenth century he occupied a distinct place. This work is in the direction of the latter since the former would require another competence.

As introductory, though, it should be noted that his contemporaries placed him alongside the best known European natural scientists and evaluated his work usually by comparing it to the work of Linnaeus and Buffon. Pallas' younger contemporaries in particular were quick to point out the significance they saw in his work, both in terms of the mass of new material he brought to light on the natural conditions in the relatively unexplored eastern regions of the Russian Empire and in terms of the scientific precision with which he presented it. Karl Rudolphi in $1812,{ }^{2}$ Georges Cuvier in

0tnoshenii, 1775-1815 (Moscow, 1966), p. 238. As a matter of fact the venerable Benjamin Franklin's work was not unrecognized in Russia. In 1789 he became the first American to be elected an honorary member of the St. Petersburg Academy and also the first American author to be translated into Russian. (Ibid., pp. 240-242).

2 "Peter Simon Pallas. Ein biographischer Versuch," in his Beyträge zur Anthropologie und allgemeinen Naturgeschichte (Berlin, 1812), pp. 3-64. 
1813,3 and $\operatorname{Karl}$ Baer in $1831^{4}$-men of scientific prominence who themselves were pioneering new fields in biology in their time--all acknowledged tre significance and influence of Pallas' work. His work became in fact standard material for biologists in the nineteenth century, including Charles Darwin. 5

Among Russian scholars Pallas was given equal honor and many of his more important works were translated almost immediately into Russian. The nineteenth-century Russian zoologist Nikolai A. Severtsov (1827-1885), in evaluating Pallas less than a half-century after his death, thought Pallas' work clearly surpassed the work of Buffon. ${ }^{6}$ In 1877 there appeared a Russian text devoted to Pallas which was designed by the author for use in schools to stand alongside his two other texts on Iinnaeus and Buffon in recording the greatest achievements in European natural history in the eighteenth century. ${ }^{7}$ And, writing in 1895 , F. Keppen claimed

3"Éloge Historique de Pierre-Simon Pallas, lu le 5 Janvier 1813," in his Recueil des Eloges Historiques..., vol. II (Paris, 1819), pp. 109-156.

${ }^{4}$ Berichte über die Zoographia Rosso-Asiatica von Pallas (Königsberg, 1831), $36 \mathrm{pp}$.

5arwin used Pallas' materiai particularly in his Variation of Animals and Plants Under Domestication and The Descent of Man.

${ }^{6}$ G.P. Dementev, "Pallas," Zoologicheskii Zhurnal, XIIII, no. 2 (1964), 262-263.

7v. Marakuev, Petr Simon Pallas, Ego Zhizn, Uchenye Trudy i Puteshestviia (Mosccw, 1877), $62 \mathrm{pp}$. 
Pallas as the single greatest achiever in Russian natural history, who could only be compared perhaps with Karl Baer $(1792-1876) .^{8}$

In modern Soviet interpretation Pallas is one of the few foreign-born members of the st. Petersburg Academy in the eighteenth century who has received even close to an adequate evaluation. Most of the academicians in Russia throughout the eighteenth century had to be recruited from abroad and relatively few in fact remained in Russia very long. Pallas was one of the few in this respect for whom, in Soviet terms, "Russia became a second homeland." With few exceptions most of the others are lumped together as "careerist adventurers" whose sole function was in retarding the growth of the Russian Academy of Sciences and more progressive Russian scientists. In any event, Pallas is given full credit for his achievements in exploration and natural history and is generally pointed to with pride as an example of the high quality of scientific work achieved in Russia in the eighteenth century.

One of the reasons Pallas has been evaluated on a plane with Iinnaeus and Buffon is that he himself chose to evaluate his findings with those of Linnaeus and Buffon and to point out the differences between them. Even before coming to st. Petersburg Pallas had successfully challenged Iinnaeus' classification scheme on several points and later, in 1780 ,

8 "Uchenye Trudy P.S. Pallasa," Zhumal Ministerstva Narodnago Prosveshcheniia, CCXCVIII (1895), sect. II, 397. 
in one of his more memorable essays read before a public gathering of the St. Petersburg Academy, chose to draw an even sharper distirction between Linnaeus, Buffon, and himself. 9 Although Pallas had high respect for both of them, he could neither accept what he considered to be the rigid and "scholastically artificial" classification of Iinnaeus based solely on morphological descriptions nor the speculative ventures of Buffon rejecting any plan or order in nature. Pallas saw himself occupying the ground between, going beyond Linnaeus' external descriptions of animals to investigations of anatomy and observations of the habits of animals in their natural habitat. On the other hand, he maintained that if Buffon had done the same (instead of limiting himself to studying domesticated animals) he would have seen that species were not subject to the degree of variation that he had claimed in his Histoire Naturelle.

Pallas was fundamentally of a different type than either Linnaeus or Buffon. He did not endeavor in his career to counter Linnaeus' classification with his own or wite a monumental Histoire Naturelle that could have improved on Buffon's because he believed that the record was far too incomplete for theoretical and speculative work of that kind. Many types of life, he believed, were not yet even known and those that were known had as yet been insufficiently studied in terms

\section{9 "Memoire sur la Variation des Animaux," Acta Academiae} Scientiarum Imperialis Petropolitanae, IV, pt. II (1780), sect. I, 69-102. Pallas read the essay september 19, 1780. 
of their anatomy and physiology. Pallas' real contribution will be seen here. In Russia he was given the opportunity and possessed the energy of body and mind to explore, discover, and systematically present a rich supply of material previously unknown to European science. To Europe the interior of eastern Russia and Siberia was virtually an unknown territory, and to Europe's scholars the publications of Pallas which illuminated large parts and various features of it became immediate and valuable sources of knowledge.

To Russia, too, the interior of its eastern regions was little known, even though throughout the eighteenth century expeditionary activity had been carried out, particularly after the founding of the St. Petersburg Academy of sciences in 1725. However, up to the Pallas Expedition of 1768-1774, which stretched from St. Petersburg to the Urals to the Caspian Sea to the northern borders of China, all of the expeditions (except the Great Northern Expedition of 17331743) had been much more restricted in area and limited in scope. Pallas' own expedition, the largest single event of his life and the basis for the bulk of his subsequent $3 c i e n-$ tific work, was only part, however, of a far wider expeditionary activity carried out in Russia in the years from 1768 to 1774, imagined by Catherine II to bring to light aII possible knowledge about her eimpire. No expenses were to be spared and nothing was too trivial to be investigated. Pallas was invited to join the St. Fetersburg Academy 
in 1767 primarily to guide in the planning of this projected enterprise and to serve as the focal point of its execution. If he had not have had an already established reputation in Europe he would not have been invited to fulfill the task, for on Catherine's instructions the leadership of the Academy was looking for the best available natural scientist.

Pallas spent the next forty-three years in Russia, enjoying an amazingly productive career and scientific prestige that $f e w$ in Europe could equal in the second half of the eighteenth century. He returned to Berlin only in the year before his death. He had presided over the planning and was the focal point of the expeditions of 1768-1774 that "have been justly called the greatest single undertaking of the Academy during the entire monarchial era." 10 His life work included some 15 published works, 6 of which were multivolume; some 150 articles, most of which were lodged in the Academy's official publication ${ }^{11}$ and in the two periodical publications that he edited, Stralsundisches Magazin and Neue Nordische Beyträge, although he also had articles placed in the publications of the Rome, Berlin, Vienna, Bohemian, Stockholm, and London Academies, as well as other periodical.

${ }^{10}$ Alexanáer Vucinich, Science in Russian Culture. A History to 1860 (Stanford, 1963), p. 150. The only other expedition of larger proportions was the Great Northern Expedition of 1733-1743, which, although participated in by Academy members, was not sponsored by the Academy.

${ }^{11}$ See the annotation to the first item listed in the bibliography (Acta.....). 
publications in Russia, and several other works that he translated and edited. ${ }^{12}$ In his major works he wrote in either Latin or German, his articles were written in Latin, German, and French, his correspondence abroad was written in whatever was the native language for whom it was directed, including in English (for instance, his letters to his longtime friend Thomas Pennant), 13 and his translation activity included translations from English, Russian, and Spanish into German. All of this is adequate testimony to the breadth of Pallas' mind. Pallas' weakness, if indeed a weakness, was that he spread himself thinly over a wide field of interests after coming to Russia, until he barely had time to complete the work in the field closest to his heart (zoology) that he meant to contribute as his major and crowning achievement-his monumental three-volume Zoographia Rosso-Asiatica--and, at that, not to his total satisfaction and he did not live to see it in print.

12 The most complete listing of Pallas' published work is to be found in Keppen, "Uchenye Trudy P.S. Pallasa," pp. 400-437. Keppen also provides partial annotation. The next best, though not as complete and not annotated, is to be found in Rudolphi, Beyträge, pp. 65-77. The article of N.M. Zelenetskii, "Petr Simon Palias, Ego 2 hizn, Nauchnaia Deiatelnost i Rol v Izuchenii Rastitelnosti Rossii," Zapiski Novorossiiskago Obsinchestva Estestvoispytatelei, XII (1916), 35-104, is essentialiy a bibliographic article, but limited to Pallas botanical work. In that respect, however, it goes far beyond even Keppen's listing and annotations are extensive.

${ }^{13}$ Carol Urness, ed., A Naturalist in Russia: Letters from Peter Simon Palias to Thomas Pennant (Minneapolis, 1967). Reproduced here are 17 of Pallas' latters to Pennant during the years from 1766 to 1781. 
Few of Pallas' works have been utilized to any extent here--only the travel accounts of his two expeditions and his two most memorable essays (memorable because they are practically his only speculative ventures). The direction of this study is that of simple biography and basic survey of Pallas' career in Russia seen against the background of the St. Petersburg Academy of Sciences that he served and the previous expeditionary activity in Russia in the eighteenth century. No attempt is made at a catalogue or independent scientific evaluation of his work. Historically it is sufficient to note that his works were greatly valued and seen as containing an important body of new scientific material, as well as heralding new approaches to scientific investigation. His most important writings (most of which I have seen and scanned) will, however, be mentioned peripr:erally in connection with his career and some annotations made to them.

The expedition that Pallas made from 1768 to 1774 has great significance for the history of Russian exploration and science, and a large section of the paper will be devoted to it alone. His later expedition to southern Russia and the Crimea in 1793-1794 was an independent venture of relatively small scope and will be dealt with fairly briefly, as will his subsequent move to Simferopol in the Crimea, where he lived from 1795 to 1810 . Sections are also included of his life prior to coming to Russia and of his career in st. 
Petersburg during the two decades between his expeditions. Historically Pallas' contribution to science in Russia appears against the background of a dawning but vibrant scientific activity in Russia. European learning in institutional form had entered Russia in 1725 with the founding of the St. Petersburg Academy of Sciences. Most of its scholars, for lack of qualified Russians, had to be recruited from abroad throughout the eighteenth century and even into the nineteenth century, but the last third of the eighteenth century witnessed the first substantial body of Russian academicians qualified to sit alongside men such as Peter Pallas, Lecnard Euler, or Caspar Wolff, and by the end of the century it was clear that the Academy was evolving into an institution of native Russian scientific achievement rather than having its rolls adorned with an overwhelming majority of foreign-born scholars. The Academy suffered setbacks and difficulties of all sorts in trying to find a permanent place in Russian society. Scientific and technical learning simply did not, as imagined by Peter $I$, spread rapidly to inspire Russian students. But learning did progress over the course of the century, if unevenly.

The role of the foreign members of the Academy was also uneven. As a whole they appear to have established serious scientific investigation and exploration in Russia, and thus to have laid the foundation for the flowering of native Russian science in the nineteenth century. But it remains 
that comparatively few foreigners can be said to have devoted their careers to the St. Petersburg Academy or to have made any particular advancement in Russian science. Many did not fit in, or try to fit in, to the scheme that Peter I envisioned of having foreign scientists plant the seed of European scientific learning into Russian youth. The story is told of Gottlieb Bayer, one of the original members of the Academy and an expert in oriental languages, who disdained to learn even the rudiments of the Russian language. ${ }^{14}$ Many others, whether or not exhibiting this sort of indifference to things Russian, packed up after only a few years and went back home. of the sixteen foreign scholars recruited from abroad in 1725 to form the Academy's original membership, seven left St. Petersburg within the first decade (three others had died), and only one ultimately stayed in Russia for his entire career (the historian Gerhard Mülier). 15 This situation is representative of the difficulty Russia had in maintaining a body of first-rate scholars from abroad and it continued up until 1766, when Catherine II introduced a few changes and a few new faces that breathed a new life into the Academy. As a result, a larger number from among

14P.F. Pekarskii, Istoria Imperatorskoi Akademii Nauk (St. Petersburg, 1870-1873), I, Ixvi; Vucinich, Science in Russian Culture, p. 84.

15 B.I. Modzalevskii, Spisok Chlenov Imperatorskoi Akademii Nauk, 1725-190? (st, Petersburg, 1908), pp. 10-14. 
Europe's best scholars came to St. Petersburg to spend their academic careers during Catherine's reign than during any previous period.

The difficulties of the Academy in its earlier years are only relative, however, to the better times that followed. From its foundation the Academy was the sole center of scientific activity in Russia and the center from which spread all subsequent Russian science. It was the beginning, and by the time Pallas came to st. Petersburg the Academy had accomplished some important pioneering work for Russian science, not the least of which was its expeditionary activity. From 1725 to the end of the century the Academy undertook to sponsor some thirty-five separate expeditions to various parts of European Russia and Siberia. Even this figure does not indicate the extent of expeditionary activity in Russia in the eighteenth century. Several fell outside of Academy undertakings and several more were undertaken before $1725 .^{16}$ Many of these expeditions were undertaken between 1725 and the time of Pallas' entry into the Academy, but the majority were undertaken during the last third of the century. To indicate the proportion of the expeditionary activity that was carried out during the years from 1768 to 1774 alone, seven separate expeditions made up the activity

${ }^{16}$ V.F. Gnucheva, ed.. Materialy dIia Istorii Ekspeditsii Akademii Nauk v XVIII i XIX Vekakh... (Moscow-Leningrad, 1940), p. 8 . 
of which the Pallas Expedition was only one, ${ }^{17}$ albeit the central one and the one which covered the most territory, and five smaller expeditions were sent out to various places in northern and southern Russia to observe the passing of Venus in front of the sun which was to occur in the summer of 1769.18 All but one of these latter expeditions extended for at least a three-year period and included much more than just observing Venus.

Pallas thus entered the st. Petersburg Academy at a time when academic life in Russia was taking a turn for the better under a beneficient empress, herself the chief inspiration for the expeditions of which Pallas was the kingpin. But the expeditions of 1768-1774, even though serving as the most productive single source of knowledge on the interior conditions of eastern Russia and areas of Siberia in the eighteenth century, did not venture into total darkness. The previous half-century witnessed the beginnings of scientific exploration and academic life in Russia, including some outstanding individual achievements, that Pallas and his companions were able to put to profitable use. Furthermore, scientific life in Russia in the half-century preceding Pallas

17 Ibid., pp. 95-106. These pages sketch the itinerary and make-up of each and provide information as to what material in the Academy archives is available. The figure "seven" does not include several branch expeditions made by Pallas' students.

18 Ibid., pp. 108-114. The explanation in the preceding footnote applies. 
deserves mention in its own right as the dawning age of serious scientific activity in Russia, and will be discussed next in more detail as forming the institutional and expeditionary background to which Pallas made his contributions. 
CHAPTER II

\begin{abstract}
THE ST. PETERSBURG ACADEMY AND ITS RECORD OF SCIENCE AND EXPLORATION IN THE EIGHTEENTH CENTURY
\end{abstract}

The history of Russian science in the eighteenth century is principally the history of the St. Petersburg Academy of Sciences--an outgrowth of Peter the Great's desire to bring European scientific learning to his country, and established as an institution in 1725 after Peter's death by his widow and successor to the throne Catherine $I$, in accordance with the plan Peter had already decreed for its organization. ${ }^{1}$ From the Academy emanated nearly all scientific activity in Russia in the eighteenth century and through its predominantly foreign membership Russia was opened to the influences from which science was able to blossom in Russia in the nineteenth century. Contrary to what Peter had in mind, however, the growth of native Russian science was slow and the progress of the Academy uneven. Peter's intention was to staff the

\title{
${ }^{1}$ Peter's plan ("Proekt"), formally announced in
} January 1724, served to outline the organization, purpose, and functions of the Arademy. In it peter directed particular attention to the role that its first foreign members were to perform, acting at the same time as pure research scholars, counselors to the court, and disseminators of science to kussian students through a university and gymnasium that were to be established as integral parts of the Academy. The "Proekt" is reproduced, among other places, in Materialy dlia Istori i Imperatorstroi Akademii Nauk, ed. by M.I. Sukhomlinov (St. Petersburg, 1885-1900), I, 14-22. 
Academy with high-quality scholars from Europe who would then prepare Russian students to fill their shoes and who in turn would thus serve as tho rucleus to further spread scientific and technical learning in Russia. For Peter the success of an Academy of Sciences on Russian soil would hinge on this development as much, if not more, as on the mere transplantation of foreign research activity to st. Petersburg. Peter provided the Academy with adequate funding and adequate incentives to attract scholars from Europe, and he provided for a university and a gymnasium to be established as part of the Academy. Commitment to the benefits of European learning, however, ran shallow beyond the range of Peter's followers.

Following Peter's death, Catherine I (1725-1727) quickly brought the actual founding of the Academy to fruition. Sixteen European scholars (all but three from Germany) arrived to form the original membership. Various scientific instruments, presses and paper, and other materials were also brought from Europe and by the beginning of 1726 the Academy was in operation. Six other European scientists were enlisted in the years 1726 and 1727 to add further luster to the Academy's rolls. The Academy by the latter year could bcast of housing some of Europe's brightest young scientists, particularly in the field of mathematics.

Following Catherine's death in 1727 enthusiasm for science dried up and under three successive rulers (Peter II, 
1727-1730; Anne, 1730-1740; Elizabeth, 1741-1761) the Academy went through a period of financial and administrative difficulties which resulted mainly from neglect. until the reign of Catherine II the Academy gave essentially the appearance of an institution apart from the rest of Russian society, administered by persons close to the court with little or no interest in learning, and supported only by the group of foreigners that comprised its membership. The neglect during the years of Peter II's reign was the most glaring for having followed immediately upon the hesls of Petrine enthusiasm for science. Under the influences present at his court the government of Russia was removed from st. Petersburg back to Moscow. The Academy's president, Lavrentii Blumentrost, ${ }^{2}$ was taken along, leaving supervision of Academic affairs in the hands of the secretary, Johann Schumacher. ${ }^{3}$ Schumacher quickly established himself as the sole spokesman for the Academy and until 1757, when he retired,

2 Blumentrost had been Peter the Great's physician and the chief organizer in the planning stages of the Academy. A capable man with an avid interest in the Academy, he was more attached to the court and after his move in 1728 to the end of his tenure in 1733 exercised none of the prerogatives of his office. See Pekarskii, Istoriia, I, 1-15.

${ }^{3}$ Schumacher, like Blumentrost, had been employed in the service of Peter the Great and was a close assistant to Blumentrost in the planning stages of the Academy and in negotiating with foreign scholars in getting them to Russia. He was well educated but his manner was offensively autocratic. All accounts agree that the Academy suffered more during its early decades from the influence he held over its administration than from any other source. A thorough account of Schumacher can be found in Pekarskii, Istoriia, I. $15-65$. 
exercised in fact near absolute power over its operation.

The difficulties experienced by the Academy during the first few decades of itz existence stemmed to a great extent from Schumacher's control. Administratively he refused to regard the opinions or interests of the academicians and frequently withheld salaries from those who crossed him. Schumacher became the central source of complaint among the academicians in an endless series of complaints sent to the government. Within a five-month period alone in 1745 there are on record nine petitions from Academy members, all complaining of Schumacher's abusive authority and the resulting depressed state of the Academy. ${ }^{4}$ The presidents of the Academy, named because they were close to the court and not because they were interested in science, normally chose not to concern themselves with the day-to-day functioning of the Academy and did not try to circumscribe Schumacher's control. This situation in the Academy's administration remained essentially the same until Catherine II introduced changes in 1766, since after Schumacher's retirement in 1757 his policies were carried on by his son-in-law and successor, Johann Taubert.

Very soon after the removal of the government to Moscow in 1728,5 it became apparent that the Academy would enjoy

4Materialy, VII, 464-465, 468-469, 480-485, 490-491, $503-510,540-546,548-555,634-647,697-700$.

5 Under Empress Anne the court was brought back to St. Petersburg in 1731, but with few favorable results for the Academy. 
little support from the new anti-Petrine court. A serious shortage of funds resulted, another feature that did not much change until Catherine's reforms in 1766. Next to petitions complaining of schumacher, requests for new grants of money became the item highest on the agenda of Academic internal affairs. The Academy presidents occasionally appealed for funds in the Academy's behalf, but with rare success.

Lack of support thus created a great deal of uncertainty in the financial situation and a great deal of arbitrariness in the administrative situation of the Academy. The effects soon became apparent as one after another of the foreign academicians began to take their bows and return homes Johann Kohl in 1727, Christian Martini and Johann Buxbaum in 1729, Jacob Hermann and Georg Bilfinger in 1730, Christian Gross in 1731, Daniel Bernoulli in 1733, Johann Beckenstein in 1735. Johann Duvernoy and Leonard Euler in 1741, Christian Goldbach in 1742, Georg Kraft in 1744, and in 1747 Joseph Delisle and Johann Gmelin (1748?). These names, plus five that died in St. Petersburg within the same period, comprise all but one of the academicians who entered the Academy from 1725 to 1727. The historian Gerhard Müller was the only one of the early members to remain in Russia for his entire career. Between 1727 and 1731 (i.e., during the entire period of Peter II's reign) not a single member was elected to fill the positions that were becoming vacant, and after 1731 people of high 
quality from Europe were increasingly difficult to recruit. The majority of those that did come to St. Petersburg, like their predecessors, did not remain long. During the entire period from 1731 to Catherine's reforms in 1766 a mere handful of productive scholars from Europe came to st. Petersburg and stayed for any length of time or until their early deaths: Johann Fischer (1732-1771), Georg Steller (1737-1746), Georg Richmann (1740-1753), A. Kaau-Boerhaave (1747-1758), and Franz Aepinus $(1756-1798) 0^{6}$

Particularly with Leonard Euler's departure in 1741 the Academy suffered a blow to its prestige. It was Euler who, along with his close friend and fellow citizen from Basel, Daniel Bernoulli, early established the St. Petersburg Academy's excellence in mathematics and helped bring the Academy in its first years into wide recognition throughout Europe. Euler was comfortable in St. Petersburg, but like Bernoulli and others before him, found that the Academy lacked adequate support to be congenial for academic life. His loss not only deprived the St. Petersburg Academy of one of Europe's great eighteenth-century minds and its foremost symbol of scientific prestige, but left a void in the field of mathematics in St. Petersburg--the field on which the Academy up to that time was able to base a large part of its reputa-

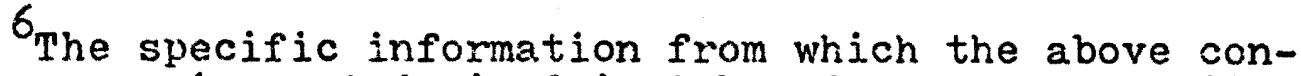
clusions are in part derived is taken from Modzalevskii. Spisok Chlenov, pp. 10-24. The dates in parentheses indicate the length of career in Russia. 
tion. Euler's chair in mathematics remained vacant for nearly two decades, until it was filled in 1760 by Simeon Kotelnikov, one of Euler's first Russian students.

Euler was such a large figure in European science that the turn in the Academy's fortunes under Catherine II was sparked in Iarge part by his return to st. Petersburg in 1766. Euler had made known his desire to return to st. Petersburg in a letter to Count Mikhail Vorontsov, contingent, however, on adequate enticements, including far-reaching changes in the way the Academy was supported and administered. Seeing in Euler's rəturn the opportunity to raise instantly the prestige of the Academy, Catherine immediately instructed Vorontsov to reply to Euler that all of his conditions would be met. ${ }^{7}$ Euler was given a substantial sum of money ${ }^{8}$ for his return and was immediately placed at the head of an interim commission to administer Academic affairs pending the complete overhaul of the administrative structure. In addition, Catherine in 1766 completely dismantled the separate office of secretary, ${ }^{9}$ which under Schumacher and Taubert had become a symbol of opprobrium for the academicians. The acquisition of Euler and Catherine's reforms, in short,

${ }^{7}$ Sbornik Imperaturskago Russkaso Istoricheskago Obshchestva (St. Petersburg, 1867-1916), $X, 58-59,67-69$.

${ }^{8} 8,000$ rubles. I. Gustave du Pasquier, Léonard Euler et ses Amis (Paris, 1927), p. 81 .

${ }^{9}$ Pekarskii, Istoriia, II, Iviii. 
ushered in "a period during which the government consistently lived up to its financial obligations toward the Academy, "10 and gave the Aca iemy considerably more permanence within Russian society.

Catherine was practically bubbling with enthusiasm for scientific prestige in her realm. She was preparing to outfit a large-scale scientific expedition to scrutinize the interior of Russia on a larger scale than had hitherto been accomplished, and at the same time another set of expeditions was being planned to observe the transit of Venus in front of the sun which was to occur during the summer of 1769. Already in 1767 Catherine ordered all necessary astronomical instruments to be procured from abroad for this undertaking and every assistance given for its planning. ${ }^{11}$

The year following Euler's arrival also saw the arrival in rapid succession of three more noted representatives of European science: Samuel Gmelin (Johann Gmelin's nephew), Caspar Wolff, and Peter Pallas. Pallas, like Euler, had to be assured of certain conditions before coming to st. Petersburg. He was originally offered a position of adjunct in the Academy and he turned the offer down, demanding the position of full academician. A new invitation was subsequently extended to Pallas in accordance with his demands. 12

${ }^{10}$ Vucinich, Science in Russian Culture, p. 160.

11 Annual Register, $X(1767), 9-10,200-201$.

12 Protokoly Zasedanii Konferentsii Imperatorskoi Akademi i Nauks 1725 po 1803 goda (St. Petersburg, 1897-1911), II, 588-595. 
ushered in "a period during which the government consistently lived up to its financial obligations toward the Academy," 10 and gave the Academy ccrisiderably more permanence within Russian society.

Catherine was practically bubbling with enthusiasm for scientific prestige in her realm. She was preparing to outfit a large-scale scientific expedition to scrutinize the interior of Russia on a larger scale than had hitherto been accomplished, and at the same time another sèt of expeditions was being planned to observe the transit of Venus in front of the sun which was to occur during the summer of 1769. Already in 1767 Catherine ordered all necessary astronomical instruments to be procured from abroad for this undertaking and every assistance given for its planning. 11

The year following Euler's arrival also saw the arrival in rapid succession of three more noted representatives of European science: Samuel Gmelin (Johann Gmelin's nephew), Caspar Wolff, and Peter Pallas. Pallas, like Euler, had to be assured of certain conditions before coming to st. Petersburg. He was originally offered a position of adjunct in the Academy and he tumed the offer down, demanding the position of full academician. A new invitation was subsequently extended to Pallas in accordance with his demands. 12

${ }^{10}$ Vucinich, Science in Russian Culture, p. 160.

11 Annual Register, $X(1767), 9-10,200-201$.

12 protokoly 2 asedanii Konferentsii Imperatorskoi Akademii Nauk s 1725 po 1803 goda (St. Petersburg, 1897-1911), II, 588-595. 
The willingness to bid high for the services of a well-known scientist, together with the enlightened atmosphere that Catherine was forging, heraloed a substartiaily new era in the Iife of the Academy in the final third of the century. The first forty years of the St. Petersburg Academy, if a disappointment in terms of the lack of support it received, was not empty in achievements or significant developments. The bulk of achievement, it must always be remembered, was registered by foreigners. The learning that Peter the Great intended for them to disseminate had only slightly penetrated through the crust of traditional Russian society by the beginning of Catherine II's reign. Education in Russia had thus far made little headway. This is not surprising when it is remembered that the changes Peter the Great inaugerated were not, to say the least, universally popular with Russia's native elite. The observation has been made by one scholar that none of the Russians elected to the Academy during the first fifty years of its existence was from the aristocratic class. 13 There were few in fact from any class, but in the $1740^{\prime} \mathrm{s}$ and $1750^{\prime} \mathrm{s}$ the first Russians made their appearance into the Academy as full-fledged academicians, forming the first page in the development of native Russian scientific and academic life. They were the few early products of the Academic Gymnasium and University, neither of which enjoyed very brilliant successes throughout

${ }^{13}$ Vucinich, Science in Russjan Culture, p. 134. 
the eighteenth century. The University in St. Petersburg never really got off the ground until 1747, then only barely and after 1767 was closed altogether for the rest of the century. ${ }^{14}$ The Gymnasium remained in operation throughout the century but with very small enrollments. Some of these first Russian scholars necessarily received their higher education abroad.

Mikhail Lomonosov and Vasilii Trediakovskii share the distinction of being Russia's first full academicians in the Academy, both elected on the same day in 1745.15 others followed, Stepan Krasheninnikov in 1750, Nikita Popov in 1751, Simeon Kotelnikov in 1760, and Stepan Rumovskii in 1767. At the time of Pallas entry into the Academy in 1767 there were several other Russians serving as adjuncts (the most notable perhaps was Aleksei protasov who became a full academician in 1771) but essentially up to that time these had been Russia's contribution to the highest scientific circle in Russia.

In terms of individual achievement, Lomonosov (17111765) perhaps stands above the rest. He possessed extraordinary scientific abilities and did work in a great many fields, but his scientific contribution was as much symbolic

${ }^{14}$ M.P. Viatkin, ed. Ocherki Istorii Leningrada, vol. I (Moscow-Leningrad, 1955), p. 414.

${ }^{15}$ Vasilii Adodurov in 1733 and Grigorii Teplov in 1742 were elected as adjuncts but never made the grade of full academician or professor. 
as real since he was the first such scientist of many talents to emerge in Russia. He devoted much energy to quarrelling with the German members of the Academy, but at the same time played a large role in advancing native Russian science and a leading part in the founding of Moscow University in 1755. And, among other innovations, he estaolished the first functional chemical laboratory in the Academy. 16

Krasheninnikov's (1713-1755) contribution is also unmistakable. As a natural scientist and member of the Great Northern Expedition (1733-1743), Krasheninnikov displayed first-rate qualities of scientific investigation. The account of his travels in eastern Siberia was one of the few Russian works in the eighteenth century to gain wide contemporary recognition abroad. 17 His early death robbed him of a more productive career, but while a member of the Academy he undertook several small botanical expeditions around st. Petersburg and from 1750 was in charge of the Academic Gymnasium, pre-

16 Iiterature on Lomonosov is vast, much of it the work of Soviet scholars who like to see in his work more perhaps than is actually the case. Nevertheless, even pre-Soviet scholars have written extensively on Lornonosov. According to Vucinich (p. 421) "one of the most detailed and objective biographies of Lomonosov ever written" is that provided in Pekarskii's Istoriia (II, 259-892 supplements, pp. 893-963). A nice summary is provided by Vucinich himself (pp. 105-116); and a short but definitive biography by Boris $N$. Menshutkin has been translated from the Russian as Russia's Lomonosov (Princeton, 1952).

17 Opisanie Zemii Kamchatki [Description of the Iand of Kamchatka](St. Petersburg, 1755). Krasheninnikov's work was translated soon after publication into English and French. A definitive translation into English, much improved 
siding during the period that the Gymnasium had its greatest success in the eighteenth century in terms of enrollment. ${ }^{18}$ Kotelnikov (1723-1806) and Rumovskii (173/-1812) were less important as contributors, but both enjoyed long academic careers and performed solidly as two of Russia's first students in the fields of mathematics.

The list of Russians qualified to sit as academicians continued to extend through Catherine's reign until by the end of the century a significant portion, nearly half, of the Academy's membership was Russian. Up to Pallas' entry a total of six Russians had been named as academicians in the Academy; from 1767 to the end of the century ten more had earned the right to sit among the circle of acadamicians and many more had served in other capacities of learned activity. The number is not large by comparison with the number of foreigners, but as a group these were the men who initially absorbed the learning of their foreign mentors and established an independent Russian tradition in science and learning. Some of them, following in the tradition of Lomonosov and Krasheninnikov, deserve independent mention for their scientific work (some will later be mentioned in connection with

over the original abridged English edition of 1764, has recently been furnished by E.A.P. Crownhart-Vaughan under the title Explorations of Kamchatka, 1735-1741 (Portlard, 1972).

18 K.V. Ostrovitianov, ed., Istoriia Akademii Nauk SSSR, vol. I (Moscow-Leningrad, 1958), p. 299; Viatkin, ed.. Ocherki, p. 217. 
Pallas), but more importantly, perhaps, they served as the transmitters of European science to a wider Russian audience. By their publications, teaching, translation astivity, textbook composition, and forward progress in establishing purely Russian institutions, a wider Russian participation in the knowledge of the day became possible.

Although the Academy was financially in distress during most of the period up to 1766, the reason goes deeper than the lack of support it received from government officials. The sheer weight of the activities connected with the Academy grew considerably during this period and diverted both attention and money from the academic center of the Academy. The printing office, various workshops engaged in the production of scientific instruments and other technical tasks, the engraving and drawing departments, the translating department, and other sidelights all required salaried workers and expensive materials. In 1727 there were 84 persons connected with the Academy, 19 of whom formed the core of academicians and ad juncts, in 1735 the number was 158,14 of whom formed the core of academicians and adjuncts; and in 1742 the number stood at nearly 400 persons, even though the number of academicians and adjuncts had further dropped to 11.19 In the latter year a strongly worded plea was sent from the Academy to the government sounding the alarm that academic life was

${ }^{19}$ Ostrovitianov, ed., Istoriia, pp. $44,152$. 
in actual threat of collapse because of the funds being diverted for these other activities and not being replaced. 20 In 1747 the Academy received its first formal charter and set of statutes from the government, which attempted to cure some of the ills and arbitrary practices that had grown up in the Academy. 21 The charter separated some auxiliary activities from the Academy proper and attempted to regularize salaries and finaricial support. In reality it did little more than formalize and even extend Schumacher's powers over the purse and personnel of the Academy. An attempt was also made to revive the Academic University (which had been provided for in 1725 but soon had to close its doors for lack of students) by stipulating that thirty students would be provided with stipends. Enrollment, however, slowly declined thereafter and after 1767 , as already mentioned, it was closed. The charter did not bring about changes in the Academy's overall situation.

The low ebb of scientific achievement in the Academy

20 Materialy, V. 79-80.

21 The document ("Reglament i Shtaty Akademii Nauk i Khudozhestv") used here is the reproduction as Appendix IV in Ostrovitianov, ed.. Istoriia, pp. 436-453. Prior to 1747 the Academy operated according to the outline plan Peter had furnished, but a specific set of statutes delineating authority, salaries, etc. had not yet been ratified. Up to 1747 the academicians continually urged in letters and petitions that their rights, privileges, and duties be set down in a ratified document in order to escape from the arbitrariness that had grown up under schumacher's handling of affairs. 
at the time of Euler's return and Catherine's reforms was no illusion. Empress Elizabeth, like her two predecessors, had been little concerned with the advancement of science, and the man she selected to be president of the Academy in 1746 . Count Kiril Razumovskii, was too involved in affairs of State to give attention to the Academy. Actual control was in Schumacher's hands and Razumovskii was content to leave it there. During the first four years of Catherine's reign (1762-1766), furthermore, no new members at all entered the Academy, and by 1766 the Academy's membership had so stagnated that the Academy possessed only two members of even moderate scientific note, Franz Aepinus and Johann Lehmann. 22 Despite the decline in purely academic research during the Academy's first four decades, much work aside from this was going on and, as already indicated, a large number of secondary activities had developed. The Academy was the main center for publishing and translating activity in Russia, and in 1738 a separate Translation Department was established in

22 Aepinus (1724-1802) was acquired in 1756 and remained an active member of the Academy until 1798. For a summary of his work, primarily in the field of physics, see Dictionary of Scientific Biography, ed. in chief Charles C. Gillispie (New York, 1970-1972), I, 66-68; and A. Wolf, A History of Science, Technology, and Philosophy in the Eighteenth Century (2nd ed.1 London, 1952), p. 236. Lehmann (1700-1767) was acquired only in 1761 and he died early in 1767. On his work, primarily in the field of chemistry, see Wolf, pp. 399-400. Working in the field of history, however, Russia was fortunate to possess at the time three scholars of note: Gerhard Müller, Johann Fischer, and August Schlözer. Of the three, Schlözer was the only one who did not remain in Russia for his entire career. He remained only from 1762 to 1769. 
the Academy which was made up of qualified young Russians. 23 An observatory was established, as were laboratories and a botanical garden for experimental work. Under Gerhard Müller extensive gathering of historical material was undertaken as part of the Great Northern Expedition. The Academy was also involved in the gathering of historical material from Russia's medieval centers; for instance, in 1735 the Academy was instructed by the government to send a mission to Novgorod to recover all available historical material for preservation in the Academic Library. 24 Further, regarding the field of history, in 1748 a separate Historical Department was established under Müller. ${ }^{25}$ For exemplary work in discovery and experimentation bonuses were awarded by the Academy. Georg Bilfinger was the recipient of one, in 1740, of 1,000 rubles for his work in experimental physics with metals even

23 Translation work carried on by Russian members of the Academy was of great importance both in stimulating efforts to modernize the Russian language and in making available to Russian readers everything from modern scientific works to ancient classics. One of the specific duties of the Russian adjuncts working under foreign academicians was to translate the ir important works into Russian. Translation activity expanded considerably in the latter part of the century, but from its modest beginnings and the concern to make the Russian language a medium of scientific learning and literature grew the first Russian language popular scientific journal, Ezhemesiachnye Sochineniia [Monthly Essays], published from 1755 to 1764. Others followed. See V.P. Zubov, Istoriografiia Estestvennykh Nauk v Rossii (Moscow, 1956), pp. $36-40$.

24 Sbornik IRIO, CXI, 463-464.

25 Materialy, IX, 125-126. 
after he had left the Academy and was merely an honorary member. ${ }^{26}$ In 1739 a Geographical Department was established under Joseph Delisle, the chief task of which was cartographic work. Cartographic productions opened in 1745 with the publication of Russia's first atlas ("Atlas Rossiiskoi"), 27 marking the beginning of vast extensions and refinements in the knowledge of Russian geography in the eighteenth century. The great progress of Russian geography was only made possible, however, by the expeditionary activity carried out in Russia in the eighteenth century.

In the words of a contemporary observer of Russia, writing at the end of the eighteenth century, "the first and most important step to the elucidation of the natural and moral condition of Russia was the appointment of the academicians of st. Petersburg to travel for the purpose of exploring its qualities in both these respects; and their journals still form the basis of all that we know with certainty of the internal state of this extensive empire." 28 The author was referring mainly to the Pallas-led expeditions of 1768-1774, the written journals of which provided him, as well as others, with the basic material from which to describe

${ }^{26}$ Sbornik IRIO, CXXXVIII, 87.

27I.S. Berg, Ocherki po Istorii Russkikh Geograficheskikh otkrytii (2ná ed.; Moscow, 1949), p. 423.

${ }^{28}$ William Tooke, View of the Russian Empire, vol. I (reprint ed.; New York, 1970), p. ili. 
"this extensive empire" to their foreign readers. And in fact these expeditions as a whole provided the largest single body of material yet to appear on the natural conditions of European and Asiatic Russia. They were the landmark in Russian eighteenth-century seientific exploration, as the Great Northern Expedition, three decades earlier, was the landmark in providing the first substantial information on Siberia, its eastern regions and beyond. Before, between, and after these two huge undertakings, that in terms of energy and time expended and in the richness of results produced in furthering existing knowledge can stand alongside any such undertaking in the history of exploration, there were numerous other expeditionary enterprises of a smaller nature in the eighteenth century. 29

The expeditions sponsored by the Academy in the eighteenth century can be separated into two groupsi those undertaken for purely geographical and astronomical purposes, and those undertaken more specifically for physical scientific observations. 30 Those classified as astronomical were involved chiefly in observing such phenomena as eclipses, in testing atmospheric conditions, and in making geographical

29 The brief discussion to follow is narrowed to the expeditionary activity undertaken under the Academy and that which seems most relevant to forming the background to Pallas ' work in scientific exploration.

${ }^{30}$ Gnucheva, ed., Materialy dlia Istorii, p. 9. 
determinations of longitude and latitude. For astronomers of the day one of the paramount tasks was in determining the exact distance of the earth from the sun and the other planets. For these determinations, the moment of the passing of a planet in front of the sun was observed and venus in particular attracted attention. The transit of Venus before the sun, it was felt, would afford the first opportunity to determine precisely the distance of the sun from the earth. Its future occurrence had been projected already in the seventeenth century, but as yet the rare spectacle had not taken place.

Twice in the eighteenth century Venus passed before the sun, in 1761 and in 1769, and both occurrences were the occasion for general excitement in the scientific world. Early in 1761 the Academy dispatched an expedition headed by Academician Nikita Popor and Adjunct Stepan Rumovskii. The expedition carried them deep into Siberia; Popor stopped at Irkutsk near Lake Baikal and Rumovskii journeyed a little further to Selenginsk. European scientific centers were braced for the event as well, and a member of the Paris Academy, Chappe d'Auteroche, was instructed to journey into Siberia for a favorable observation point to augment other observations that would be carried out in France, He chose Tobolsk as the point to set up his equipment. In d'Auteroche's words, "the whole learned world had taken all possible measures to assist the observation. Sovereign princes, although engaged in an 
expensive war, had neglected nothing that could insure the success of this important matter . . . 31 For the Russians, inclement weather at the moment of the long-awaited event prevented them from gathering any information and they returned to st. Petersburg after charting some geographical points.

Catherine II would see to it that the next time Venus presented itself the Academy would be better prepared with more and better observation points, determined as she was that Russia make as large a contribution in this field as anybody else. Two years of preparation went into planning for the next projected transit of Venus in front of the sun and out of these preparations grew plans for a separate enterprise to investigate the interior conditions of Russia on a more comprehensive scale than had yet been accomplished. The execution of the 1769 astronomical expeditions will be described in connection with the total expeditionary activity of $1768-1774$.

Prior to the 1760 's the Academy dispatched several expeditions for specific astronomical and cartographic purposes. The passing of the planet Mercury in front of the sun in 1740 was the occasion for Joseph Delisle, the Academy's chief astronomer, to be sent to Berezov. Ten years earlier Delisie's brother. Louis Delisle de la Croyère, returned from a three-

\section{${ }^{31}$ Chappe d'Auteroche, A Journey into Siberia (reprint} ed.; New York, 1970), p. 81. 
year expedition (1727-1730) to Arkhangelsk and other northern regions for the purpose of making geographical determinations, and ten years later (1751-1753) Christian Kratzenstein undertook an expedition to the north of European Russia to observe a solar eclipse and to carry further the charting of geographical points in the north. The list could be extended, but pointlessly. They were small affairs of little consequence singly. Combined, however, they provided the basis for more precise geographical knowledge of European Russia which, added to other types of expeditions that stretched further and lasted longer, gave to the St. Petersburg Academy the distinction of advancing geographical work by leaps and bounds, making it possible for others, like Pallas, to advance with more sureness and accomplish more.

Before the expeditions of 1768-1774, perhaps the bestexplored and best-mapped regions on the eastern fringes of European Russia were those of the lower Volga and the areas around the Caspian Sea. Even before the founding of the Academy several of Peter the Great's military officers had carried out extensive investigations and mapping around the Caspian and in the northern Caucasus region, in accordance primarily with military objectives. Several more small expeditions were undertaken in the south and along the Volga to report on flora, minerals, and the like. Undoubtedly the most important of the pre-Academy expeditions was that of Daniel Messerschmidt (1685-1735), a physician in Peter's 
service, who was sent into southern Siberia in 1720 to investigate the geography, the peoples, and all matters of interest to natural history. Over a seven-year period Mosserschmidt traveled through a great deal of territory, collected and brought back an immense amount of material, and left for those who followed a lengthy account of his travels. Future travelers to northern Central Asia and southern Siberia were much indebted to Messerschmidt for his pioneering scientific exploration into Siberia, the accounts and maps of which often served as their guide as to the conditions and peoples that were likely to be encountered. Pallas, almost a halfcentury later in his own travel account, made frequent acknowledgements of Messerschmidt's work and is quoted as having remarked that "one cannot help but marvel at what this man alone has accomplished." 32

Peter I was well-attuned to furthering the geographical knowledge of his realm. As is well known, he personally wrote the instructions for the First Bering Expedition (17251730), which was instructed to voyage along the shores of northeastern Siberia. Whis was only the last of the instances of Peter's desire to krow and chart the limits of his expansive empire.

32 Pallas quoted in V.I. Mezhov, Sibirskaia Bibliografiia (st. Petersburg, 1891-1892), II, 259. Messerschmidt's ten-volume account of his travels remained in manuscript and only recently has its publication been undertaken. However, Pallas subsequently published some extracts from Messerschmidt's journal (with an introduction) in the periodical that he edited, Neue Nordische Beyträge. III (1782), 97-158. 
After the founding of the Academy, expeditions of a natural scientific eharacter increased. They were undertaken by mon with greater scientific talents than Peter's officers in the Caspian region or even Messerschmidt had possessed. The beginning of physical scientific exploration for the Academy could not have been on a grander scale.

The apparent inconclusiveness of Bering's first voyage in the northern waters (to determine whether America and Asia were separate) led to the organization of another expedition under Bering's command. The Academy was not yet in operation at the time of Bering's first departure, but was eager to be included in this second venture. Without the Academy mombers present on the Great Northern Expedition 33 it would still deserve the laurels that have grown up around its accomplishments--chiefly, the final determination that Asia and America were separate continents, the mapping and discoveries made in the northern Pacific, and the actual landing made on North America. With the Academy members present the significance as well as the enormity of it. were greatly enhanced. It was "a national migration on a small scale," as one observer has seen i.t. 34

The details of the trek across Siberia and the sea

${ }^{33}$ Its most fitting title, but also called the second Bering or Second Kamchatka Expedition.

34 Peter Lauridsen, Vitus Bering, trans. by Julius E. Olson (Chicago, 1889), p. 79. 
voyages will not be dealt with here. What is most important in forming the background to Pallas' expeditionary work is the foundation laid by the naturalists or this expedition in providing the first substantial body of scientific information on Siberia. The chief names to mention in this connection are Johann Georg Gmelin, Georg Wilhelm Steller, and Stepan Krasheninnikov.

of the three, Gmelin is the most significant as a predecessor to Pallas' expedition. Gmelin spent ten years (17331743) traveling through the heartland of siberia, the results of which were recorded in his two major works, Reise durch Sibirien von dem Jahr 1733 bis 1743 (the account of his travels, Göttingen, 1752) and Flora Sibirica (the study based on his collected botanical material in four volumes, st. Petersburg, 1747-1769). Pallas' route across southern Siberia covered much of the same general area through which Gmelin traveled. Gmelin's works were used to great advantage by Pallas, but he saw his general purpose in covering this part of Gmelin's traveled territory as observing it more thoroughly than he thought Gmelin had. 35

Steller became a member of the Academy in 1737 and joined the expedition only in 1739--in time, however, to accompany Bering on his epic voyage to Alaska. Steller also spent

35P.S. Pallas, Voyages de M. P.S. Pallas, en Différentes Provinces de l'Empire de Russie, et dans L'Asie Septentrionale, trans, by M. Gauthier de la Peyronie (Paris, 1789-1793), III, 4-5. 
several years traveling in the peninsula of Kamchatka and when he finally set out to return to st. Petersburg he never made it beyond Tiumen in western Siberia, where he died in 1746. Steller's material and his principal work, De Bestiis Marinis (written while stranded with Bering on Bering Island in the winter of 1741-1742 and published in 1751), were borrowed from liberally by Pallas in his zoological studies and his fame, says Steller's biographer, was "augmented in no small degree" by the use of it. 36 on his way through Tiumen in December 1770 Pallas paid tribute to steller by visiting his tomb, 37 and Pallas later edited and prepared for publication steller's journal. of his sea voyage. 38

Krasheninnikov was only a student at the time of his participation in the Great Northern Expedition, but so distinguished himself as a capable natural scientist that he was elevated to membership (as an adjunct) in the Academy of Sciences in 1745, becoming in essence the first distinguished naturalist of native Russian background. Krasheninnikov's

36 Leonhard Stejneger, Georg Wilhelm Steller (Cambridge, Mass., 1936), p. 488. On Fallas' indebtedness to Steller's material see also Academy of Sciences of the U.S.S.R., The Pacific: Russian Scientific Investigations (New York, 1969), p. 137; Pekarskii, Istoriia, I, 605-606.

37 Pallas, Voyages, II, 518.

${ }^{38}$ G.W. Steller's Reise von Kamchatka nach Amerika mit dem Commandeur-Capitan Bering (St. Petersburg, 1793). Pallas also procured and published other material of Steller's. See Keppen, "Uchenye Trudy P.S. Pallasa," p. 434; Pekarskii. Istoriia, I, 597; Stejneger, Steller, pp. 349n, 504n. 
work centered around his travels in the peninsula of Kamchatka, his account of which constituted the means by which the scholarly world of the day got its first comprehensire glimpse at this remotest of remote siberian regions. 39

These were the men to whom Pallas looked as having established in a grand fashion the scientific exploration of siberia. He knew their works intimately and relied upon them, while at the same time making improvements to their scientific accuracy. As a result of the authoritative information gathered by these men in regions of Siberia that stretched beyond the limits of his own expedition, Pallas was also able to round out his general zoological and botanical studies of European and Asiatic Russia.

Gerhard Müller was also, of course, an important member of the Great Northern Expedition from the Academy, whose most notable contribution was in gathering historical material. Müller, like Gmelin, spent the years from 1733 to 1743 traveling through Siberia from one end to the other and, like his colleagues, turned an energetic mind to a region offering endless opportunities for novel study. Müller thus did not bury himself solely in family archives, but did work in geography and gathered significant ethnographic material as well. Although Müller's work was not as closely related to the area of Pallas' studies as was Gmelin's, Steller's, or Krasheninnikov's, Pallas knew Müller's work as well as any.

${ }^{39}$ See above, p. 26. 
After Pallas came to St. Petersburg he and Müller (the only one of the Academy participants in the Great Northern Expedition still living at the time) became close collaborators on Siberian matters and freely made their material available to the other. Pallas made a point of keeping Müller in close personal touch with all phases of his own expeditionary work. 40 The Great Northern Expedition overshadowed in every respect all other expeditionary efforts in Russia in the first half of the eighteenth century. During the decade from the mid-thirties to the mid-forties of the eighteenth century when the men of the Great Northern Expedition were exploring the interior and farthest reaches of Siberia, however, no less than five small scientific expeditions had been undertaken to the southern Ural and Caucasus regions. ${ }^{41}$ From the mid-forties to the mid-sixties of the eighteenth century scientific exploration proceeded on a much reduced scale, but far from reached a standstill. At least ten expeditions were undertaken between the time of the close of the Great Northern Expedition and the beginning of the Pallas Expedition, none of which were large or especially momentous, wide-ranging scientific expeditions, but all of which serve as further

40 . Hoffmann, "Die Briefe von Pallas an G.F. Mülier," in Lomonosov, Schlözer, Pallas, ed. by E. Winter, vol. XII of Quellen und Studien zur Ceschichte osteuropas (Berlin, 1962), pp. 310-314.

\section{${ }^{41}$ See Appendix.}


evidence that Pallas in 1767 entered a country with an already well-established tradition in scientific expaditionary activity.

ore expedition during this period stands out as being more extensive and more closely related to the area of Pallas" expedition than the others: that of Erik Laxmann from 1764 to 1769. It was also ciosely related in time, as Laxmann was just returning from southern Siberia as Pallas was getting a good start in that direction. Laxmann was sent into southern Siberia primarily for the purpose of investigating its mountain and mineral ragions. Most of his time was devoted to mineralogical researches in the Altai Mountains, which point he did not go beyond. As far as Laxmann's work went, Pallas utilized it and regarded it as an authoritative source on the Altai Mountains. It had not been Laxmann's purpose, however, to engage in an all-encompassing scientific expedition--the factor that distinguishes the historical importance of both the Great Northern Expedition and the Pallasled expeditions of $1768-1774.42$

42 Erik Laxmann (1737-1796) surely deserves to be called ore of the prominont figures in Russian exploration in the second half of the eighteenth century. He returned from his first expedition in 1759 tc be ramed as an academician in the Acadeny ine following year, and spent the major part of the last twelve years of his life (1784-1796) exploring again in southern siberia. He died, as a natter of fact, in Tobolsk. His researches remained most closely related to mineralogical matters. Soviet scholanship has taken note of Laxmann's contributions in a recent bjography by N.M. Raskin and I.I. Shafranovskii, Erik Gustavovich Iaksman: Vydaiushchiisia Puteshestvennik i Naturalist Wyi v. [Erik Gustav Laxmann: Prominent rraveler and Naturalist of the Eignteentin Century] (Leningrad, 1.9?1). 
Several summary observations and further comments need to be made about the St. Petersburg Academy of Sciences that Pallas entered in 1767 and remained a part of for the next forty-three years. The picture appears mixed. At the same time that expeditionary achievements ware being carried to fantastic proportions from the mid-thirties to the mid-forties of the eighteenth century, the Academy in St. Petersburg was undergoing strains serious enough to result in the loss of several of its most brilliant members (Daniel Bernoulzi. Leonard Euler, Christian Goldbach, and Georg Kraft) and in an overall decline in the quality of its membership. By whe fifties, when the results of the Great Northern Expedition were beconing know in published form to all of Europe and the individual work applauded, the prestige of the Academy had suffered further and alarms had even been heard that its very existence was in question. Looking objectively, however, a bustling behind-the-scenes activity in the workshops, the printing office, the Geography Department, and so forth, was going on and expanding. And, more importantly for the future of Russian science, Russians were making their soientific debuts, Still, the Academy as an institution remained an anachronisn in Russian life. It received little government support, and advances in education in Russia that would have given the Acadomy a more solid base remained negligible. Catherine II set in motion the forces that would change all that. 
Imbued, at least for a time, with the desire for intellectual prestige to Flourish around her, Catherine gave the Academy more support and promised its menvers an era of prosperity. The quality of the Academy's foreign membership rose unmistakably as did the spirit in which they worked. More Russians entered the Academy as intellectual life in Russia spread beyond the narrow limits of the St. Petersburg Academy. Not far beyond these linits, to be sure, and Russia was still heavily dependent on foreign scientists to make up the composition of the Academy, but Moscow University was in operation throughout the final third of the eighteenth century (unlike the Academic University) and in 1783 an allRussian scholarly institution was founded, the Russian Academy, devoted to Russian language and literature. 43 In the same year Catherine named as Director of the St. Petersburg Academy a woman with lively intellectual interests. Princess Catherine Dashkova, who followed upon a tradition of inept, disinterested, or insensitively autocratic directors of Academic affairs. Dashkova was instrumental in the founding of the Russian Acadeny and, alorg with her duties as Director of the St. Petersburg Acaderny, was named its first president. "An ambitious, educated, ana capricious woman" ${ }^{4.4}$ and a voman

43 Tre Russian Academy existed as an independent body until 1841, when it was merged with the St. Fetersburg Acadery of Sciences and becane its Department of Russian Langliage and Isiterature.

$$
{ }^{44} \text { vucinich, Bcience in Russjar Culture, p. } 142 .
$$


with a "restless and turbulent spirit," 45 Dashkova undertook her responsibilities with a serious interest in expanding and improving tre position of science in Russia.

The men Catherine II appointad to head the Academy prior to 1783 were hardly congruent with her declared plans for reorganization and reform in the Academy's administration. Both Count vladimir Orlov (1766-1775) and Sergei Domashnev (1775-1783) were ostensibly only the guiding light of the new Academic Commission that was made up of the Academy's ovm members. From the first, however, the government did not consider any of the proposals for permanent statutory changes put forth by the Commission and as an administrative body it began to lose significance after it was instituted in 1766. Orlov was not a man of science, but he was not a hindrance to Academic activities and apparentiy got along well with the academicians. 46 Domashriev, on the other hand, recalied to the Academy the days of Schumacher. He interfered obnoxiousiy in the Academy's work and created constant tonsions in his relations with nost Acadeny nembers. According to Princess Dashkova, Domashnev's behavior toward the academicians drove Leonari Evler to disassociate himself

45 Desciotion of a contemporary English envoy in Russia. Sbornik IRIO, XIX, 436.

${ }^{46}$ upon his jeparture as Director of the Academy in 1775 he is reported to have entertained all of the academicians to dinner. K.S. Veselovski. "Borba Akademikov s Direktoroin S.G. Domashnevym," Russkaia Starina. IXXXVII (July-Sept., i896), 458 . 
altogether from the Academy's affairs and to take no interest in its proceedings. 47 Ironically, the occasion of Domashnev's dismissal and Dashkova's appointmert in 1783 was also the occasion for the abolishment of the Academic Commission, signaling the government's firm intention to keep the Academy closely under its wing. 48

There can be no question of Princess Dashkova's service to the Academy (both Academies for that matter) and her desire to see science and learning take a stronger hold in Russia. Her own literary achievements were also widely known--even in America, where she was well known to Benjamin Frankin and was elected an honorary member of the American Philosophical society in 1789. 49 Simultaneous with her tenure as Director, however, official. policy in Russia began to deliberalize. Particularly in the $1790^{\circ} \mathrm{s}$, as a reaction to the French Revolution, tightened censorship poijcies of the government began to weigh heavily on the Academy. In 1796

47 The Memoirs of Princess Dashkov, trans. and ed. by Kyril fitzlyon (London, 1958), p. 209. The adverse effects of Domashnev's tenure are revealed in all accounts, but most thoroughly in the documented article cited in the precedirig footnote and in a collection of documents relating to his tenure: "Direiktor Akademii Nauk Sergei Gerasimovich Domashnev," Chteniia v Imperatorskom Ooshchestve Istorii..." IIX (oct,.-Dec., 1866), sect, V, 134-184.

48 Nova Acta Acaderniae Scientiarum Imperialis Petropolitariae, I (1.783), sect. I, 3-5; The Memoirs of Princess Dashkov, p. $20 \mathrm{c}$.

${ }^{49}$ Bolkhovitinov, Stanovlenie, p, 236. 
printing was restricted by Catherine, several printing offices were abolished outright, and a restriction was placed on the importation of fureign materials. 50 paul I (1796-1801) extended Catherine's censorship decrees and in 1798 placed a near total ban on the importation of all printed material. 51 The Academy was essentially cut off from European science and its members registered their complaints of this situation openiy. Even their scientific papers that were to be inserted in the Academy's journal, Nova Acta, had to first pass the approval of a government censor. 52

The atmosphere in the Academy during this troublesome time was made even more annoying by Dashkova's nephew and. successor as Director, Paul Bakunin (1794-1798), a tictless and uneducated man who squandered the Academy's funds and added misery to the academicians' lives. 53

${ }^{50} \mathrm{~K} . \mathrm{S}$. Veselovskii, "Otnoshenij.a Imperatora Pavja I k Akacemii Nauk," Russkaia Starina, XCIV (1898), 237.

51 Ibid., pp. 242-245; Annual Register, XI (1793), 59. 62. Paul's extensive of ficial censorship policies, although odious to the academicians, does not appear to have extended to Faul's persoral relations with the Academy. In 1798 he saw to it that Bakun in (mentionsd in the next paragraph) was removed as Director and appointed in his place a man favorable to scionce, Andrei Nikelai. The concluding point of Veselovskii's artjole cited in tinis and the preceding footnote is that peul took an antive interest in the Academy's activities and his personal attitude tcward the acadenicians was at ali times favorable.

52 protoloIy, IV, 522-523,763.

53 G.A. Kniazev and A.V. Koltsov, Kratki Ocherk Istorii Akademij Nauk SSSR (3rd ed.; Moscow-Leningrad, 1964), 
With the accession of Alexander I to the throne in 1801 the prohibition on the importation of books and materials from abroad was abrogated. With the abrogation, the scholars in St. Petersburg publicly declared that a new era was opening for science in Russia. 54 In 1803 the Academy received a new charter which served to further brighten the outlook of the Academy. This document ${ }^{55}$ recognized for the first time the right of kcadeny members to elect their ow new menbers and to participate more actively in decisions that afiected their activities. The charter of 1747 provided for only ten full academicians; the charter of 1803 provided for eighteen. The budget was increased, and, of fundamental concern to the academicians, the presidents of the scademy could no longer be chosen arbitrarily by the government but were to possess integrity and intellect.

Pallas, fortunately, had taken leave from st. Petersburg to live in the crimea just before the bleak period of strict censorship and general Academic decline during Catherine's latter vears and Paul's reign, During the time of his active participation in the Academy, however, Pallas participated in an era of lively and relatively unfetterec scientific

pp. 28-29; K.S. Yesolorski, "Poslodnie Gocy Proshlago Stoletila v Ákadernii Nauk," Russkaia Starina. XCIII (1898), $227-243$.

54 protokoly, IV, 908.

55"Reglament Imperatorsko i Akademii Nauk." Reproduced in protokoly, IV, 1138-1185. 
growth in Russia. His personal contribution was no small factor in that growth. There will be occasion to further elaborate upon ine improved position of the Acadeny and the growth of science in Fussia under Catherine II in later sections of the paper dealing specifically with Pallas. 


\section{PART TWO}

PALLAS' EXPEDITIONARY AND ACADEMIC CAREER IN RUSSIA 


\section{CHAFTER III}

\section{PAIJAS: EARLY YEARS}

At the time of his ertry into the St. Petersburg Academy Palias was twenty-six years old and a well-recognized figure in European science. The Academy could not gain his services by offering him the secondary position of adjunct, as most of the other members entered; rather he came as a full academician. 1

Born in Berlin in 1741, the son of a Prussian doctor. and a Frenoh mother, Pallas could enjoy relative comfort while receiving an excellent education. His first biographer mentions that at the age of thirteen Pallas commanded the use of Latin, English, and French, as well as kis native tongue, German. 2 ht that juncture, in 1754, he began attending lectures at the Medical-Surgical College in Beriin, where his father was teaching. Unti]. 1758 Pallas remained at the College, preparing himself for an advanced education in the field of medicine. He embarked on this course first, in the fall of 1758 , at the University of Halle, where he remained only until the spring of 1759. After returning for a short

${ }^{1}$ See above, p. 23.

${ }^{2}$ Rucoiphi, "Peter Simon Pallas. Ein biographischer Versuch," p. ". 
while to Berlin, Pallas then set out to study at the University of Göttingen, where he stayed about a year. In July 1760 he was off for Ioiden, where his studies tominated at the end of the sane year and he presented and defended his sixty-two-page dissertation, ${ }^{3}$ receiving then the degree of Doctor of Medicine. Pallas was nineteen.

The next seven years of Pallas' life were spent very productively, but also a little uncertainly as to a future career. His own inclinations appeared to run in a different, direction from those of his father, who would have liked his son to establish a practical career in medicine. To further this design, Pallas was sent by his father to London to observe medical practices and hospitals soon after he finished his studies at Leiden. Pallas remained in England until April 1762, extending his activities there to include visitations to England's collections in natural history, making the acquaintance of English scientists, and making excursions of his own to the coasts of England for the purpose of studying

3 pallas dissertation on parasitic intestinal worms, Dissertatjo medica inauguralis de infestis viventibus intra viventia (published in Leiden, 1760), by all accounts was a work of solid advance in science. Pallas recognized and sought to show that intestinal worms, contrary to prevailing thought, enter the body from the outside (for instance, through food) and by elelineating types of worms pointed out Iinnaeus errors in their classification. At the time, worms were little known to science and Pallas returned periodically during his lifetime to carrying out further studies in this area, establishing for himself a significant role in the history of helminthology. I.S. Kirichenko, "Ocherki iz Istorii Veterinarnoi Gelnintologii Dorevoliutsionnogo Vremeni. Petr-Simor Fallas, "Irudy Vsesoluznogo Instituta Gelmintologii, XV (1969), 147-151, Rudolphi, "Peter Simon Fallas. Ej.n biographischer Versuch," pp. 10-11. 
marine and other life. Pallas left England "with regret" upon his father's summons, returning to Berlin in the summer of 1762. 4 In Berlin Pallas learned that his fatier had commissioned him as a field doctor in the army, and he set out almost immediately for Hanover, where in a very short while he found his services no longer needed due to the termination of the current hostilities (Seven Years' War). Back in Berlin he could find nothing in the way of a permanent occupation that interested him and after a year decided upon seeking opportunity in Holland, the best equipped country of the day for undertaking studies in natural history. In August 1763 Pallas setsiled in The Hague, where he remained until November 1766 ergaged in intensive study but a fruitless search for a desirable position.

The product of Pallas' work in Holland established a reputation for him as one of the bright young minds in Europe. In 1764 he was elected a Fellow of the Royal Society of Iondon and in the following year was elected a member of the French Académie des Curjeux de la Nature. 5 In 1766, before he departed from the Hague, two of his works appeared in print which further brought his talents to the attention of the

4 The reference to Falias' regret at being called away from Fngland is that of William Coxe, Travels into Poland, Russia, Sweden, and Dermark, vol. III (reprint ed.; New York, 1970), p. 207.

${ }^{5}$ C.H. Smith, "Memoir of Pallas," in The Naturalist's Jibrary, ed, by Sir William Jardine, vol. TX TEdjnburgh, 1839). p. 24 . 
scholarly world: Elenchus Zoophytorum and Miscellanea Zoologica.

Elenchus Zoophytorum was dedicated to the zoophytes (or "animal-plants") and succeeded in accomplishing, in the opinion of Rudolphi, one of the essential pioneering scientific views of the day. 6 The work was primarily descriptive of various kinds of sponges and corals, and as introductory to it pallas attempted to show that all life was interconnected, like a tree and its branches. The idea of absolute division between the animal and plant kingdoms of nature, Pallas maintained, was false; the zoophytes formed the transition between them. Pallas proceeded in his vork to describe about 270 different kinds of sponges and corals, pointing out their animal characteristics in order to prove that they were not actually plants although they appeared as such. By his singular and intensive focus on the zoophytes Pallas pro. vided perhaps the best contemporary work on the subject. which was also very timely since the question of the possible animal nature of corals was just beginning to be opened in Europe. 7 The work was very popular and was translated aimost immediately into Dutch and German. Cuvier claimed at the

\footnotetext{
6 "peter Simon PaIlas. Ein biographischer Versuch," pp. 15-16.

PB.E. Raikov, Russkie Biologj-Evoliutsionisty do Darvina. $1 . .$, vol. I (Moscow-Leningrad, 1952), pp. 46-47. Seepp. 67-80 for conjecture as to Falliss evolutionary views associated with this work and a few other examples of his early writing.
} 
time he delivered Pallas' eulogy in 1813 that Pallas' analysis of the zoophytes was a commoniy accepted scientific fact. ${ }^{8}$ Miscellane 20ologica, as the title suggests, was a collection of studies on various animals, vertebrates and invertebrates alike. In it pallas continued his study into the then obscure species of the animal kingdom, bringing to light detailed features of little-known animals. In it also, Pallas continued to draw attention to the inadequacias he saw in Lirnaeus classification. ${ }^{9}$ And in a prefixed note to the Prince of Orange, to whom the work was dedicated, Pallas set forth a proposal in which he offered to undertake and lead a voyage to the Cape of Good hope and to the Dutch East Indies, Apparentiy Pallas' plan was made known to the prince who agreed to sponsor such a venture, but Pailas' father refused consent and called him back to Berlin, in November 1766.10 Pallas' three-year stay in Holland firmly established his reputation as a brilliant and eager student of natural history. It also made him known in some circles as an overexuberant critic. Referring to Pallas' Elenchus Zconhytorum. 114.

8"Éloge Historique de Pierre-Simon Pallas," pp. 112-

${ }^{9}$ Ibid, pp. 115-11?; Rudolphi, "peter Simon Pallas, Ein biographischer Versuch," pp. 17-19; J. Victor Carus, Geschichte der Zoologie bis auf Joh. Mïller und Charl. Darwin (Munich, 1872), pp. 536-537.

${ }^{10}$ Smith, "Memoir of Pallas, " pp. 32-33; Coxe, Travels,
pp. 209-210. 
John Ellis, a well-established English naturalist, wrote to Iinnaeus early in 1766 stating that Pailas "has treated both you and me with a freecion unbecoming so joung a man ... if he does not act as a gentleman. I shall take particular notice of his criticisms in the rook I propose to publish, which I hope will travel as far as his."11 Alexander Garden, an American naturalist from South Carolina, thought little better of Pallas' manner in either the Elenchus or Miscellanea, writing to Ellis in 1768 that "as far as I could judge, his latinity is the best part of his book. As to the quarto, I really think it is so glaring and gross a catchpenny, that I am amazed how he cculd have the effrontery to publish it, and attack Monsieur de Buffon, whose labours in that way must do him eternal honour, and confer infinite obligations on all the lovers of Natural History."12 Pallas was young and no stickler for scholarly niceties, A few years earlier, however, Pallas had been kinder to Iinnaeus by supplying him with a work he had compiled containing thirty-eight names and descriptions of new species of birds, thirty five of which were incorporated by Iinnaeus in the twelfth edition of his Systema Naturae $(1766) .13$

${ }^{11}$ Sir James $E$. Smith, ed., A Sejection of the Correspordence of Iinnaeus and other Naturalists (Lordon, 1821), I. $185-186$.

12 Ibid., pp. $565-566$.

${ }^{13}$ C.D. Sherborn, "The New species of Birds in Vroeg's 
Fallas' return to Beriin resulted in nothing in the way of occupational opportunities, but his scientific work was not daunted. Kis collection of zcological stridies in Miscellarea zoologica was continued under a new title, Spicilegia Zoologica, which ultimately consisted of fourteen separate studies but only the first four of which were completed before he went to Russia. 14 pallas had also just begun to edit (anonymously) a periodical publication, Stralsundisches Magazin, before his departure to Russia. The first two issues, containing many of Pallas' ow zoolngical studies, were prepared in the first half of 1767.15 And, closer to the direction that his father intended his activities to follow, Pallas completed in 1757 a German translation of Richard Brookes' sizable two-volume the General Practice of Physic, a modern English medical handbook that Pallas had begun to render into German while in Holland. 16

Catalogue, 1764," Smithsonian Miscellaneous Collections, XIVII (1905), 332; and the companion article immediately following, C.W. Richmond, "Notes on the Birds Descrjbed by Pallas in the 'Adumbratiuncula' of Vroeg's Catalogue," 342.

14 The full collection of these studies was published in two volumes in Berlin $(1757-1780)$.

15 In 2.11, Fallas edited the first six issues of this publication (1?6?-1770), arter whjch editorshin was changed. These six issues are all cortained in one volure.

16 Keppen, "Uchenye Trudy P.S. Pallasa," p. 433; Rudolphi, "Peter Simon Pallas. Ein. biographischer Versuch," pp. 7?-78. 
Although Palias later branched out to include in his field of study a variety of interests, his basic work in his early years was in 200 ivgy, and his revulation within this field had been built to a large extent on his investigations into the nature and structure of lower animals. Pallas' belief that the animal world did not lend itself to fixed schemes of classification led him into endeavors to show that Iinnaeus and his followers took into account too few examples of living forms and too littie descriptive information about their make-up. The central aspect of Pallas' work was thus the many new lower species that he dealt with and the more detailed methods that he used to describe thein. He went beyond description by external characteristics alone to investigate also internal structures of animais and to make deter.. minations of geographical distribution. Pallas was aware that outer features in some cases belied an animal's true nature. On one occasion, for example, he directed ettention (in Miscellanea Zoologica) to the resemblance in anatomy of a type of worm he had dissected with that of insects. ${ }^{17}$ All of Pallas' work was characterized by great detail and meticulous care in illustration.

Fundamental to the way Pallas went about his studies in his early years was his belief that all forms of life were interconnested from the lowest forms to the highest and did

17Keppen, "Uchenye Truay P.s. Pallasa," p. 390. 
not necessarily exist in a static condition, but were capable of change and development. Pallas did not theorize much on the subject of the changeability of species, but he was an early adherent of Caspar Wolff's recently declared theory (1759) of epigenesis which held that new species can and do exerge ${ }^{18}$ and was fully up-to-date on Joseph Koelreuter's recent botanical studies in plant sexuality and hybridization, both of which carried important implications for future directions in biological studies. ${ }^{19}$ The interest that Pallas' early work held for his contemporaries was rather in the mul itude of novej. species that he investigated and the practice to which he was devoted of doing anatomical investigations. If Caspar Wolff was the early forerunner of Karl von Baer (1792-1876) in establishing the study of embryology, Pallas was the forerunner of Georges Cuvier (1769-1832) in firmly establishing studies in comparative anatomy. Cuvier acknowledged his debt.

All of the qualities of his early work Pallas sharpened as he aged. The St. Petersburg Academy was fortunate that he aged in its midst; and it must be said in reverse that

18. Streseman, "Leben und Werk von Peter simon Pallas," in Iomonosov, Schlözer, Pailas, p. 255.

19 On Koelrauter see R.C. Olby, ed. Late Eighteenth Century European Scientists (Oxford, 1966) pp. 33-65. Both Wolff (1733-1794) and KoeIreuter (1733-1806) spent part of their careers in the St. Petersburg kcademy of Sciences: Wolf from 1767 to his death in 1794; Koelreuter only from 1756 to 1701 . 
Pallas was fortunate to have been called to the north, where opportunities in abundance awaited his brand of scientific scholarship. At the enu of 1766, when ti.e first invitation arrived from St. Petersburg, Pallas was deeply involved in his zoological studies, but his scientific work was as yet unsponsored. Still, his star in the past three years had ascended with great rapidity and his future appeared bright enough to allow him to decline the initial offer from st. Petersburg. His father, who was against the st. Petersburg idea and wanted his son to establish himself in the field of medicine in Berlin, may have also influenced Pallas' decision. But Pallas left the door open by opting for better conditions from the St. Petersbirg Academy, which were quickly agreed to. In view of the fact that Pallas was first on the Academy's list to be invited to fill the existing void in the field of natural history and to guide in the planning of the projected expeditions, the offer of the position of Professor of Natural History, which Pallas demanded, was extended with little hesitation. 20 In April 1767 Pallas indicated his acceptance of this second offer; in May his future arrival was formally announced before the full Academy, 21 and two months later, in July, he was in attendance for the first time in a session of the Academy in St. Petersburg.

${ }^{20}$ Pallas had come to the attention of the St. Petersburg lcademy initially through the recommendation of a Professor Ludwig at Leipzig, who had been asked in 1766 to recommend the best young and available practitioner of natural history of which he was aware.

21 The occasion for a moment of hearty applause by the Academy members. Protokoly. II, 504. 
CHAFTER IV

\section{THE PAIIAS EXPEDITION}

In 1767 a dozen years had passed since the St. Petersburg Academy had been represented in the field of natural history-since Krasheninnikov's death in 1755. The arrival of Pallas in the summer of 1767 filled the void with eminence. Only weeks before Pallas' arrival other long-standing voids in fields relating to natural history were also filled, twentyone-year-old Samuel Gmelin in the chair of botany and thirtyfour-year-old Caspar Wolff in the chair of anatomy and physiology. From this point natural history and its related fields developed into well-grounded parts of science in Russia. And it was the intellectual guidance of Fallas which was in the main responsible for raising to maturity the first real core of native Russians in this area of science, similarly as it was Leonard Euler's tutelage under which there emerged a solid beginning of a native Russian tradition in the fields of mathematics. More immediately, it was Pallas' leadership of a remarkable six-year expeditionary era which proved to be the training ground for a group of young Russian students in natural history. In this lies one aspect of Pallas contribution to science in Russia and in the long run perhaps one of the most significant for the future growih of science in Russia. 
The expeditions of 1768-1774 gave the largest and most enduring boost to the study of the natural conditions of the Russian Empire in the eighteenth century. They also produced the greatest bulk of material yet to appear of Russia's interior condjtions. It happened that the focal point of those expeditions was also one of the focal points of European science, and asiae from his personal scientific work and accomplishments in Russia. Falias was resident there for a good long while tc inspire and preside over the spread of his own work. The accomplishments heralded by Pallas in Russia-expeditionary and otherwise--were only in step, of course, with the overall improvement in science and the Academy's position under Catherine II. Leonard Euler's ret:rm to st. Petersburg in the sumner of $1766^{1}$ put the seal on and set the pace for the new era. And, even though the expeditions of Pallas and his colleagues were the main center of attention around the Academy in St. Petersburg, the prestige that scientific life in St. Fetersburg held for the outer scientific world centered around Euler and his mathematical wizardry. After Eulen's death in 1783, according to one estimate, "i.t was Fallas above all who kept the prestige of the St. Petersbuxg Academy at enviable heights." 2

${ }^{1}$ Euler's eldest son, Johann $(1734-1800)$, entered the Academy at the same time as Professor of Physics. Although as a scientist he never attained the reputation of his father, until his death he was one of the key members of the Academy as its permanent secretary.

$$
2 \text { vucinich, Science in Russian Culture, p. } 152 .
$$


In 1767 pallas was among the front rank of European natural scientists, and in zoological studies he was rapidily carving out his niche as the forenost European representative. Before departing for st. Patersourg he had even formulated plans for writing a general Symopsis of Quadrupeds, which he did not, however, have the leisure to complete after being invited to st. Petersburg and the task was transferred to the hands of Thomas Pennant, whose acquaintance and friendship Pallas made while resident in The Hague. ${ }^{3}$ But there were many worthy minds in Europe who were expanding the limits of knowledge about plants and animals and they were all eclipsed by the reputations of the great Iinnaeus and the King's gardener in Paris, who was issuing forth volume after volume of his Natural History. Pallas was only just emerging into the light of this scientific arena--brilliant, adventurous, looking around for some manner of sponsorship, willing and itching to go anywhere that would afford an opportunity to enhance his studies and his career. In the Hague he has thought of a scientific expedition to America, but enthusiasm was not gonerated among those who might sponsor such a venture. His proposal. for a venture to the Dutch

3 Pallas and Pennant were similariy anti-Linnaean in outlook and the Synopsis was intended to stand in opposition to the brand of classification heralded by Iinnaeus. In a letter to Pennant Pallas critically referred to the followers of Linnaeus as "modern systematicks," by which he meant to slap at what he saw as the overemphasis in classifying the species at the expense of more detailed methods of observation. Jrness, ea.. Letters, p. 11; Annual Register, XIVI (1804), 750 . 
possessions in the East did generate enthusiasm in Holland, but his father's wishes against it prevailed. For the moment the impetuous son was idmed. But, father or no father, the offer from St. Petersburg was too good to let pass by. Here was the chance for exploration and a prestigous and salaried position in the same Academy that housed Leonard Euler all rolled into one. Pallas set out, finding upon his arrival in St. Petersburg not only a new environment but a tetally new responsibility as the premier natural scientist, the front rank itself of natural science in Russia.

The position that Pallas filled in the st. Petersburg Academy--Professor of Natural History--carried with it the immediate responsibility of guiding the preparaion for an expeditionary enterprise, together with his nomal duties in the Academic sessions of presenting the fruits of his researches or giving talks on zoological curiosities. At Catherine's instructions, preparations were already in the making and instruments being procured from abroad for expeditions to favorable points from which to observe the upcoming spectacle (known well in advance) of Venus yassing in front of the sun. Catherine, in her visions to make good her claims to forging an enlightened realm, also set the wheels in notion for the planning of a simultareous expedition of a purely natural historical character to make more thoroughly known the very little known regions of the Russian Empire. The first step had been to provide the Academy with a man to guide it. 
The upcoming transit of Venus was the big event, and as originally planred the natural history part of the expeditionary enterprise nin to be only a sidelight. Under Pallas' guidance it tumed into the main event. The year that intervened between the arrival of Pallas in St. Petersburg and the time expeditionary detachments began to depart--July 1767 to June 1768--was one of serious preparatory activity for Pallas, to match the already wel1-advanced astronomical preparations. He had a lot of learning to do, together wi.th itineraries and instructions to prepare. Who had ventured forth previously, and into what? What had they observed and mapped? What instrustions had they followed? What routes did they take? What hazards had they encountered? What had they collected? These questions and more Pallas undertook as his homework to answer, pursuant to which he occupied hinself in the Academy library, museum, and archives. 4 'Working closely with Pallas in these matters was the young Samuel. Gmelin. By October the general outline of the natural historjcal part of the expeditions had taken shape, having by this time assumed an entirely independent character consisting

4 The library and museum, both housed in the same building (along with the observatory) on Vasilevskii Island, sufferea heavy damage in $174 \%$ as a result of fire. The museum was particularly hard hit. (Ostrovitianov, ed.., Istorjia, $p .178$.$) This meant that pallas did not have the$ advantage of seeing and studying many of the collections of former travelers, wich made the axtonsive collections that he and his colleagues gathered all the more valuable as a boon to studies in ratural science in Russja. 
of several detachments of its own and intended to encompass the general areas of eastern and southern Russia. The folLowing May (1760; Failas and Gmelin presented their plans and general instructions before an scademic session; they were approved, sent up for official approval, and sent back for official signirg by all members of the Acadeny. 5

The instructions as finally approved for the orenburg Physical Expeditions, as the series of expeditions over which Pallas was in general supervision were officially known, specified that everything that could be of possible use to the State and to the spread of scientific knowledge was to be surveyed. 6 A detailed journal was to be keyt by each participart recording his observations of the ollowing specifically mentioned matterss (1) the nature of the land and water over which their travels would carry them; (2) the state and methods of agriculture; (3) the general economy of populated places, their advantages and deficiencies, and to offer improvements to backward native methods of going about thingsi (4) diseases among native inhabitants and animals, and to offer preventive measures where possible; (5) beekeeping, silk-making, livestock-raising, and woolmanufacturing; (6) fishing and other arts and trades; (7)

Sprotokely, II, 637-643.

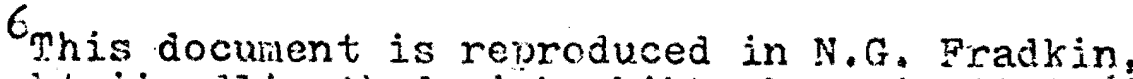
"Instruktsia dlia Akademicheskikh Ekspeditsij 176́-1774 5g.," Voprosy Geozrafij, XVII (1950), 21.5-218. 
commerce; ( 8 ) minerals, mining works, and all other manufac.. turing carried on; and (9) methods of medicine. And to be certain that the exploiers were kept busy, they were instructed to work for the improvement of geographical and meteorological knowledge; to observe and describe local customs and rites; gather whatever could be gained of local antiquities; and, finally, to observe and collect all noteworthy natural objects and curiosities pertaining to natural history. The expeditions that ensued were not to be leisurely excursions, and it is not difficult to imagine that the resulting journal accounts would be far from nice literary travelogues. The nucleus of the instructions laid it dow that a large part of what was desired was an investigation into the natural wealth and productivity of the remoter regions of Russia. The regions of Siberia that were to be traversed were not specified, and in fact Pallas' penetration deep into Siberia was never originally planned. What was planned were three separate expeditionary detachments that would make their way to the Orenburg or southern Ural region and two that would make their way to the Astrakhan or southerr Volga region. Pallas was to lead the main detachment to the Urals. Whey were all expected to terminate in 1772, but these plans were destined to be modified. Before fitting in the details of Palias travels it will help to see the outines of the total scope of the expeditions of $1768-1$ ??t, usually referrea to as a whole as the 
Academic Expeditions of 1768-1774, Together they appear, according to one observer, as the culmination of the development of Acadenic expeaitionary activity in the eighteenth century. 7 To another, "these expeditions, in extent and results, had no equal in any country in the eighteenth century." 8 Certainly they were far more extensive than the labels attached to them (Orenburg and Astrakhan Detachments) would indicate. But the most impressive feature is the amount of expeditionary activity that was crowded into these years.

For good reason the Academy was buzzing with excitement by the summer of 1768 , a good portion of its membership was soon scheduled to depart on enterprises to which the Empress Catherine herself had assigned high pricrity. For many months previous to the summer of 1768 the greatest activity and discussion in the Acadeny centered around the preparations for the moment of departure. For the upcoming astronomical event, five separate expeditions were outfitted for departure in 1768 and 1769 under the general leadership of stepan Rumovskii, by now the Academy's chief astronomer. 9 Rumovskii

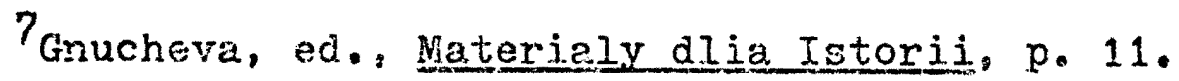
8radkin, "Instruktsiia," p. 213.

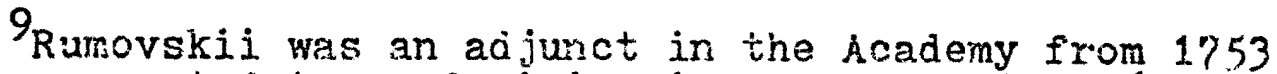
ard was promoted to academician in astronomy in 1767. filling the chair left vacant by the death of Augustine Grischow in 1760, Rumovskii, one of Leonard Euler's fomer students, enjoyed a full and productive half-century of Academic life, retiring from the Academy only in 1803, nine years before his death. 
led his own expedition to northern Russia (Kola) in 1769, observed there the passing of Venus in front of the sun with greater success than he had had in 1761, arid returned to st. Fetersburg in 1770. For the compiled observations that he later drew up and published, 10 however, he was dependent also on the observations of the other expeditions, all of which were more extensive than Rumovskii's own.

Captain Ivan Islenev (Isleniev) led an expedition which embarked in 1768 for the heart of siberia, stopping at Iakutsk on the Lena River. This expedition returned to st. Petersburg in 1771 only to embark agein for two more years of geographicai and cartographic work which took Islenev as far as the shores of tine Black Sea. ${ }^{11}$

Georg Lowitz (i722-1774), a Bavarian astronomer and mathematician from the University of Göttingen who joined the Acadeny in April 1768, was placed in charge of the astronomical work to be carried out in southeastern Russia. His own expedition in duration was the most extensive of all the expeditions sent out to observe the passing of Venus, ending tragically for himself in hugust 1774 and officialiy with

10 Nablindenie Iav]eniia Venevy -.. v 1769 godu... [observation of the passing ot Venvs : 0 in 1769 . to, however) that according to Vucinich ( $\mathrm{p}, 148$ ) "helped Joseph Delemabre to determine the mean horizontal parallax of the sun."

${ }^{11}$ Islenev became an acjunct in the Academi in 1771 as a member of the Ceographicai Departnent. He died in 1784. 
the return in 1775 of his chief companion and student, Peter Inokhodtsev $(17+2-1806)$, a Russian ad junct in astronomy. Lowitz set out late in 1768, traveling as far as Guriev on the northern shores of the Caspian Sea where he set up his equipment to observe verus. Afterwards nis expedition took on a more general exploratory character in southeastern Russia, particularly along the Volga. 12

Two other expeditionary detachments were under Lowitz's general guidance in the southern Ural regions one led by Christopher Euler which made its way to Orsk; the other led by Wolfgang Kraft which made its way to Orenburg. Both expeditions arrived back in St. Petersburg by the end of 1771.13 In size and o erall reslitts these expeditions were totally eclipsed by the other half of the expeditionary activity of 1768-17?4 led by Pallas, although at the time they were

12 Or Lowitz's death in 1774 see below, p. 79. Inokhodtsev later became a prominent Russiar member of the Academy. He was elevated to academician in 1793 and, like most other Russian academiciars after 1783, vas a member of the Russian Academy. Lowitz's son Tobias (1757-1804), incidentally, later gave exemblary service to the Acadeny as its chief chemist from 1790 to his death in 1804.

${ }^{13}$ Christopher Euler $(1743-1812)$ was Ieonard's youngest son and at the tine a Ijeutrnant in the Russian army. He was later to become a Generai. He was never a member of the Academy, choosing the more physical side of lifo, and it was no doubt his father"s influenca that secured him his place in the expeditions of 1763-1?74. Nevertheless, he was scientifically ircisned and an able participant. Wolfgarg Kraft (1743-1814) was the son of Georg Kreft...-one of the first members of the st. Petersburg Academy and a well-known experinenter in physics in his tine, violfgang came to Ruseia only in December 1768 and was sert off immediately, being slevated befors his return to Professor of Physies. He remained subsequentiy in St. Petersburg until his death in 1814. 
seen as arms of one gigantic enterprise. Besides contributing to Rumovskii's important work they compiled a wealth of geographical knowledge, contributing thus to the knoviledge that enabled the Geography Department to publish more than sixty separate maps between 1769 and 1776 and to issue a new general map of Russia in 1776.14 Nevertheless: Palias and his naturalist colleagues deservedly occupied the spotlight, not only for later observers but for contempcrary members of the Academy as weil, who waited anxiousiy for their periodic reports and crates of collected objects to arrive. Their instructions specified that reports were to be frequent; their journal accounts were to be written in manuscript during the winter months of each year and the annual installments sent back to st. Petersburg; ana all animals, birds, fish, insects, plants, thirgs unearthed from the ground, or anything else of general interest were to be crated up inmediately for shipment back to st. Petersburg. Even a casual parusal through the Proceedings (Protokoly) of the Academic meetings for the years $1706-17 ? 4$ reveals that a great amount of time anci interest was taken up by reading each progress report and personal letter thet was sent back, by reading the annual journal accounts, and by uncrating and putsing on display all of the interesting objects. Pallas alone sent forty-seven progress reports, at least haif that nany crates of objects, a good supply of more informal letter's addressed either to individual

${ }^{14}$ Berg, Qcheris po Istorii, r. 428 
members or to the Academy in general, and two manuscript. volumes of his voluminous three-volume travel account during his six years of trave.. ${ }^{15}$ The output of the other major expedition leaders was comparabie, and all of this material was preserted before the general sessions of the Academy for al]. to see and hear. 16

Johann Güldenstädt (1745-1781) and Ivan Lepekhin (17401802) were the first to lead their expeditions out of st. Petersburg--June 19, 1768. Two days later Pallas followed, and two days after that Samuel Gmelin (1745-1774) pointed his horses and carriages eastward from st. Petersburg. Johann Falk (1727-1774) followed some months later, leading the last of the original five detachments.

Güldenstädt, born in Riga and educated in Berlin and Frankfurt-on-Oder, came to St. Fetiersbuig as a young dcctor only in April 1768 and was hustled off before the formal

15 pallas carried the manuscript for the third volume with him upon his return. The first volume was published in 1771; the second in 1773; the third in 1776, together more than 2,000 pages with many maps and illustrations. The original title was Reise durch verschiedene provinzen des Russischen Reichs and it has recertly been reprinted in its criginal three-volume form (craz, Austrias Akademische Druck-u. Veriagsanstalt, 1967) together with a lengthy iorward by Dietmar Henze and a reprint of Rudolphi's list of Pallas works, Translated editions into Puench (5 vols. plus Atlas, 1789-1793), Russian (3 vols, 1773-1788), and Italian ( 5 vols., 1316) were made, but so far as I know the only rendering into English exists in very abridged form as vol. II of John Irusler's the Habitable Word Described (Loridon, 1788).

16 The 1747 charter specified that the Academy nembers were to meet three times per week in general session, but the neetings usualiy varied between one axd three times per wsek. 
ceremonies of electing lim a member of the Asademy could be carried out. Late in 1769, during his absence, he was elected an adjunct and i: $\$ 771$ became Professor of Natural History. After his travels he remained in st. Petersburg until his premature death in 1781. Güldenstädt was the first to leave and the last to returm, arriving back in St. Petersburg in March 1775 after having occupied himself for nearly seven years traveling mainly in the Caucasus region but also in the. Ukraine and northem Caspian regions. A very lively sort of man and very ambitious, Güldenstädt put off his return to je able to carry out more investigations until. instructions were sent from the Academy specifically ordering him to retum. Güldenstädt studied and wrote widely, but never got around to preparing his travel account for publication, a task that Pallas undertook arter Güldenstädt's death and pubIished under the title Reisen durch Russland und im Caucasischen Gebürge. 17

Lepekhin (Lepyokhin) was one of Russia's up-and-coming young scholars and accounted for himself splendidly on this venture and throughout the remainder of his career. Educated

17 In two volumes: vol. I in 1787; vol. Ir in 1791. Pallas also prefixed to this work a short biography of Güldenstädt and or other occasions showed appreciation of Cüldenstält's work by preparing for periodical publication some of his shorter scientific work that was lying about in the archives. A brief eulogy to Guidenstëd was prepared after his, death by an unknown hand (more than iikely Pallas"): "Précis de la vie et des ouvrages de Monsieur Jean Antoine Guldenstadt," Acta Academiae Scientiarum Imperialis Petropolitanae, V. pt. T (1781). sect. $1,9-16$. 
in the Academic Gymnasiun and at Strasbourg University from 1762 to 1767 . Lepekhin returned to st. Petersburg before the end of the latter year as a Doctor of Medicine and entered the Acadeny as an adjunct in natural history less than a month before the start of his expedition. While away, in 1771, he was elevated to Professor of Natural History. Lepekhin was accompanied by the young Nikolai Ozeretskovskii (1750182\%), then a student in the Academic Gymasium and later to distinguish himself as a foremost Russian academician. Together they followed the customary route to Moscow, over to the Volga and down the Volga to its mouth at Astrakhan. Northerly through the Urals and eastward to Tobolsk, Lepekhin then altered his route (177i) from the originally planned itinerary and zigzagged his way north, finally to Arkhangelsk. The best of Lepekhin's contribution was carried out here, where he spent about a year traveling extensively along the northern shores. From Arkhangelsk Lepekhin returned to St. Petersburg just in time for Christmas and the New Year's festivities inaugurating the year 1?73. He was the first to return, but after three months was off again to spend the remainder of 1773 investigating regions in western Russia and along the Baltic.

In the travel literature that resulted from the expeditions of 1768-1774 Leperhin's account (in four volumes) 18

${ }^{18}$ Dnevaye zapiski Pubeshestviia po Razrym Provintsijam Rossiiskogo Gosudarstva LJournal of Travels in Various Provinces of the Russian State] (St. Petersburg, 1771-1805). 
was second to none for containing a wealth or new knowledge, particularly as regards the northern regions of European

Russia. Subsequentyy he worked on a number of enall criginal works, but more important were his efforts in other areas. Like most of his fellow Russians in the Academy, Lepekhin was involved in a great amount of transiating work and alone translated the majority of volumes of Buffon's Histoire Naturalle into Russian. 19 An important theorist Iepokhin was not, but his versatile productivity was very indicative of the increasing number of productive Russian scientific minds that emerged in the last third of the eighteenth century to carry a tradition of native Russian scientific accomplishment into the next century. His student, ozeretskovskii, carried it twenty-five years further than Lepekhin into the nineteenth century, after having first joined the circie of academicians in 1782 .

For the other two principal leaders of these expeditions, aside from pallas, the enterprise had its tragic side. Samuel Gmelin, a young doctor and botanist from Tübingen University, carried out his investigations in the same general area as

The first three volumes were published from 1771 to 1780; the fourth was prepared for publication later by ozeretskovskil. The first three were translated into German almost immediately and in Russia went through several editions.

19 A task inspired by Catherine II and to which a tear. of Russians had been assigned. Iepekhin did the last six volumes and part of the first. Published, in all, in ten volunes (1789-1808), Zubov, Istorjosrafita, pp. 73-74. 
Gülderistädt, between the Black and Caspian Seas and along the western shores of the Caspian. On two occasions Gmelin ventured to the Eouthem shores of the Caspian irto Persian territory, and while returning north from the second such venture (February 1774) was captured and held for ransom by a local khan somewhere in the vicinity of Derbent. IIl and depressed, Gnelin died in captivity in July 1774 before the ransom money could arrive. Except for the material he had sent back to st. Petersburg beforehand, most of his notes and collections were confiscated by his captors and were recovered only later. Gmelin's student, Ivan Mikhailov, led the remnants of a shattered expedition bacis to St. Petersburg. complete, however, with some of Ginel in's travel notes for the last phase of his travels. 20

Johan Falk's demise was self-inflicted. Falk came from Uppsala, where he had studied under the great Iinnaeus, in 1768 to direct the Academy's botanical gardens. Designated late to lead a final expeditionary detachment to the orenburg region, Falk was some nonths behind the others, but, traveling rapidly, caught up to Pallas around Samara (Kuibyshev) on

20 Under the editorsing of Fallas these notes subsequently (in 1784) became the fourth rolume of Gmelin's journal account, Reise duch Russland zux Untexsuchurg der drey Naturreiche, to which teilas also prefixed a short bicgraphy of Gmelin. The first three volumes were published before Gmelin's death (1770-1773), and all four volumes were immediately translated into Russian. The affair of Gmelin's capture and his several months in captivity has been brought to light by a series of Gmelin's and Mikhailov's letters reproduced in tht article "Akademik Gnelin," Russkii Arikiv, I, pi. 3 (1912), 68-c2. 
the middle Volga by the miäle of May 1769 and for a week or two traveled in his compary. At forty-one, Falk was one of the older members of the expeditions and far the most physically unprepared for the rigors of exploration, having been a hypochondriac since early life. Already at Samara Falk was showing signs of decline, and the following summer the Academy sent out the recently acquired chemist Johann Georgi (1.729-1802) to help him fulfill his instructions. Together they traveled in the southern Urals and as far east into Siberia as Barnali on the upper Ob River, from where Falk had to quit altogether at the beginning of 1772 and Georgi along with the rest of the expedition was merged into the Pallas Expedition. Falk began a leisurely return, ending at Kazan where he was bed-ridden for some months before a fit of melancioly set in and he committed suicide in March 1774.21

The rigors and dangers involved in the expeditions actually exacted a moderate toll, considering the harshness of the elements during certain months (on one occasion the mercury in Pallas' Delisle thermometer compietely solidified), the sheer physical exertion expenaed in traveling overland for several thousanas of miles by horse and carriage (sometimes by sled and sometines by boat), and the unpredictable behavior of native inhabitants through whose territory the

${ }^{21}$ Falk's travel account was subsequentiy put together and gublished by Georgi in three volumes. Beyträge zur topographischen Kenntmiss des Russischen Reichs $(1785-1787)$. Georgi, born in Pomerania and educated, like Falk, at Uppsala, remained a distinguished nember of the st. Fetersburg Academy until his death in 1802. 
explorers sometimes passed. The most brutal danger was experienced by the astronomer Georg Lowitz, who in August 1774 while conducting observations along the Volga was caught in the midale of the Pugachev Rebellion and was summarily hanged. 22 For the rest, the dangers and difficulties were other than human-inflicted and were calculated well enough in advance to avoid the worst severities. Thanks in part to the planning and guidance of Pallas, the expeditions were actually conducted with a fair degree of precision and a large degree of success. Nevertheless, even for a main as young and energetic as Pallas the expedition was a grueling and battering experience, combined at tines with the satisfaction and tranquizity of traveling under blue and calm skies observing nature at its most beautiful, and at other times with the depression brought on by fatigue, illness, atmospheric chaos, or roads two feet deep with mud. Nobody had to tell Pallas when it was time to come home; after six years and forty days of scientific exploration he was, as he tells it, a gray-haired man of altered health, although yet only thirty-three years of age. 23

22 pugacher was a double menace to the expeditions. According to one account, the diversion caused by the Pugachev revellion (1773-1774) incervened to spoij. Catherine's intention of sending an armed force to liberate Gmelin from his captors in the Caucasus. "Gmelin, Samuil," Russki Biograficheskii Siovar. V, 397.

23 Vovages, $V, 382$. 
The number of persons who traveled with Pallas was not large, no more than were included in the other contingents. From the Gymnasium three students of promising vaient were chosen to go along: fourteen-year-old Vasilii Zuev (Zuyev), twenty-year-old Nikita Sokolov, and Anton Valter. For Zuev (1754-1794) and sokolov (1740-1795) it was the beginning of bright careers. An jllustrator and a taxidermist were present. The military was represented by Captain Nikolai Rychiov, 24 but more agreeable to Pallas was the presense of his wife, who was with him throughout the ordeal. In addition, there were several persons who served as cooks and hunters and a varying number of guides who were picked up in the different localities along the way.

Amid a warm send-off Pallas and company left St. Petersburg behind on June 21, 1768, traveling along the well-worn road to Moscow expecting to return in about four years. Moscow was reached in short crder (July 4 ) and after a tenday stop there, where Pallas got to know Gerhard Müller, a course was resumed winich led southeast to Penza and northeast to Simbirsk (Ulianovsk), which was reached Soptember 22. Already Pallas haa accumulated a mountain of information on everything from the customs of the Chuvash to the prevalence and nature of petrifications, and, like any nomnal male

24 The son of Peter Rychkov (1712-1777), who in 1759 becane the first Russian member-corresfondent of the Academy and in 1762 won scholarly praise for his crenburgskaia Topograriia [Orenburg ropography]. 


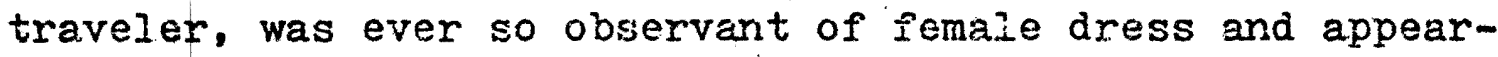
ance. Sornewhere in the neighborhood of $800-1,000 \mathrm{miles}$ had been covered thi- far, ircluding side-excursions.

Pallas remained in and around Simbirst until the following March, getting to know the Kalmyks of nearby Stavropol, the Bulgars, the Voiga and its fishes, and the animals and vegetation of the surrounding area. Mairly he was waiting for the winter to come and $g c$, which by the middle of catober was sufficiently well along that in order to cross the Volga on one occasion he had to leap from one iceberg to another. January and February were spent rather quietly in Simbirsk, preparing reports and a couple crates of objects to send back to the Academy and in writirg up his travel notes. 25 Before departing from the vicinity of Simbirsk on March 10, 1769. after nearly six months there, Pallas came upon the first of his many discoveries of elephant remairs, which he conjectured had been deposited this far north by the receding waters of a gigantic flood many centuries ago that had originated from the south as a result of some geological catastrophe. 26

25 one of his reports from Simiirsi was so long and interesting to his colleagues in St. Petersourg that they took an entire session in reading and discussing it alone. They were also immediately fascinated with one of Palias' crattes which contained iossils. Protokoly, II, 662-670,

26 Vovages. I, 214-215. Shortly afterwards Pallas came across othe: fossil remains of large mammals (rhinoceros and buffalo) to which he applied the same theory, but more importantly he immediately wrote up a separate and iengthy article describing and comparing these finds ("De ossibus fossilibus, craniis praesertim Rhinocerctum atque Buffalorum, observationes") anu sent it back to the Academy. It was 
With snow stilj. falling and ice still on the Volga, Fallas followed its course south to Samara, where he spent abcut a month surveying ite environs before venturing on at the beginning of hay. In a fow days he was at Syzran and after a four day rest stop continued southerly along the Volga, meeting ip with both the Falk and lepekhin contingents about the midale of hay. Lepekhin continued south; Pallas and Falk returned north to Samara, where they both recovered for a couple of weeks from a "slight indisposition." Recovered and parting Falk's company, Pallas left the Volga in mid-June to make his way directly for orenburg in the western Urals, a distance from Samara of about 300 miles which was reached in two weeks (July 1).

Through July to the middle of August the domain of Pallas was the southern Urals. By the middle of the eighteenth century there had grown up in the Ural region a fairly wide metal industry (mostly iron and copper) and factory system, and it was one of Pallas' inair tasks to survey the extent of mining and metallurgical plants as weil as to survey the potential for greater wealth coming from the Urals. Much of his time was thus spent visiting various mines and mining woris, studying minerals and rocks, and detailing the

read before a sesition of the Academy and lodged in the 13th volume of Novi Commentari i (1768), pp. 436-477. I.T. Kaneev has claimed this work as one example of the large role played by Pallas in the development of the science of paleontology. "O Paleontologicheskikh Rebotaik P.. . Paliasa," Voprosy Istorii Estestvozniniia i Tekhniki, XIII (1962), 146. 
pertinent information. He became especially engrossed in observing jasper and ventured the opinion that it was formed from a variously.colored clay petrified over time. 27 Mountain structures and rock formations wers the object of his scrutiny as well. In geology (not yet, of course, a separate science) Pallas was as avid an observer and as fertile with ideas as in his other endeavors. Ethnographically, too, Pallas was keen to delineate the native inhabitants of the region he was traveling through, in some cases living among them for several days or weeks and describing their life and customs very thoroughly. 28

Pron the Urals Pallas descended the Ural River to Guriev on the northern Caspian, arriving there August 24. Professor Lowitz was there at the time along with his student peter Inokhodtsev and Christopher Euler, all with their attention fixed on the sky. Pallas enjoyed their company but had more earthly things to attend to and after a week set out to return north by the same route he had just traveled. This time his destination was further north into the Urals than the area he had just traversed. He was headed for ufa, about 200 miles north of Orenburg, to establish his winter headquarters. Iljness and early signs of the approach of winter

\section{Voyages, I. $414-416$}

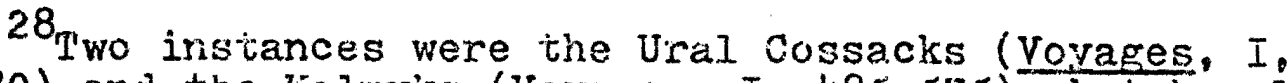
$442-480$ ) and the Kalmyks (Yoyages. I. 485-5'75) but he also delineated at lesser jergth the Tatars, Kirgiz (Kazakh), Tunguses, Buriats, Bashkjrs, and Mongols. 
induced him to rush his trip and hold his other observations to a minimum. Ufa was reached at the beginning of Dctober. In his first report from Ifa to the Academy he requested that he be sent the volumes of Johann Gmelin's Flora Sibirica to supplement his other reading in preparing him for future travels eastward. 29

The winter of 1769-70 was a severe one and due to flooding caused by the melting of a large accumulation of winter snow Pallas was unable to leave Ura until May, eight months after his arrival. Understandably ufa made a bad impression with him and he was very glad to leave. But in the meantime Pallas was far from idle. During the months of November and December he traveled sruth by way of orenburg, back to the Volga and, north by way of Stavropol, back again to Ufa, completing a square of not less than 800 miles. After that he spent his time putting together his journal notes into manuscript form, he composed a separate and sizable treatise on his zoologjcal work for the year, and in the immediate vicinity of Ufa added to his ever-growing collection of elephant bones.

Beginning in mid-May, Pallas travels for the year 1770 were confined chiefly to metallurgical and mineralogical investigations in the Jrals, within the triengular area formed by Uia on the west, Cheliabirsk on the east, and the area around Verkhoture on the north. His investigations in this

$$
\text { 29Protokoly, II, } 719 .
$$


regard were extensive, 30 but carriad out more because of necessity than desire. Ye was certainly fatigued by the Urals and all of its rijing works by the first of September. when he arrived back in Cheliabinsk resolved that nothing more of extensive exploration could be planned for the year and that there would be his wintering place. His summer gatherings were crated up into fifteen boxes and sent on their way.

Two of Pallas' companions were perhaps having a better time of it in 1770. Rycrkov had been sent by Pallas to study the Kazan region and Sokolov since February was coliecting material around the Caspian Sea. Both rejcined pallas in Cheliabinsk around the end of september. Sokolov so impressed Pallas with his independent initiative and precision in observation that Pallas inccrporated (with propen acknowiedgement) much of Sokolov's material. into his cwm work and kept him plenty busy with independent work for the remaining four years. Rychkov was soon to part company with the expedition. Complaining of jilness, he remaijed in Cheliabinsk when the others headed cast the following spring, waiting for permission from the Academy to return to St. Petersburg. From September to Decender 1770 Pallas was fairly inactive in Cheliakinsk, havine contracted an annoying eye inflammation. Sokolov became the virtual workhorse of the

30 As has been stressed by $R$. Portal, "Pallas im Ural (Mai bis August 1770)," in Iononosov, Schlozer, Palias. pp. 2 r $6-286$. 
expedition, twice auring this winter making extended excursions to points that Pallas was unable to include in his owm itinerary. But hy mid-December Pailas was restless and resolved to at least a little travel, winter or no. By sled, Tiumen to the northeast yras reached in a mere three days, and after paying homage at the grave of one of his predecessors (Steller) he went on to Tobolsk the rext day, accompanied by Jepekhin whom he had found winterine in Tiumen. Pallas spent a week in Tobolsk doing not much more than surveying the tow and conferring with Lepekhin about the coming year's travels. He was back in Cheliabinsk on the second day of the new year, 1771.

In extent the Pallas Expedition had gone about as far as it was intended it should. The Urals had been examined; at least to Pallas' satisfaction, and that was the firal najor target embodied in the instructions of Pallas, Lepekhin, and Faik. Out of the meeting between Pallas and Lepekhin, however, grew the outline of a new plan that would considerably extend the scope of the expeditions. Lepekhin would be sent in a northwesterly direction to the White sea ${ }^{31}$ and Pallas would aim eastward for Lake Baikal, observing the southern Siberian frontiers that Gmein three decacies earlier had traversed, but, according to Pallas, had been overly occupied in his observaticns with botanicai matters to give a very thorough account of the region. The plan was proposed in a letter to 
the Academy and accepted. It remained only for the winter tc break for Pallas to begin the most memorable phase of his expedition-the phase that adeed to it tha distinction of being one of Russia's most far-reaching land expeditions besides being one of the most soientifically productive. The first trree months of 1771 were given to writing and relaxing. At the end of February the young $Z$ uev got his first moment of trial by a brief excursicn south into the Central Asian steppe, and when that was done by an independent expedition of nearly a year's duration, 32 zuev was to foliow the Tobol River to where it meets the $O b$ and follow the $O b$ to its mouth in the north. To entrust so young a man with so extensive a journey showed a great deal of confidence in Zuev's maturity and ability ( 2 uev was now seventeen years old)-a confidence fully justified later. Sokolov was still Pallas' right-hand man.

In March Falk, being joined now by Georgi, arrived from the other side of the Urals to meet up with Fallas in Cheliabinsk in crdor to coordinate their itinerary with the new plans. On April 16 the explorers left cheliabinsk behind. Pallas, anxious to be under way and very much looking forward to the new phase of $h$ is travels, headed directly east for Omsk. Falk and Georgi were also heading east but by a more northerly route.

\footnotetext{
${ }^{32}$ Zuev rejoined pallas the following January in Krasnoiarsk.
} 
Omsk, a distance from Cheliabinsk of about 500 miles, was attained in about a mionth. The travel was fairly constant and not especialiy conforiabie due to the flurries of winter that had not yet fuliy retreated to allow for spring. Another month brought Pallas, by a southeasterly course along the Irtysh River, to Semipalatinsk on the eastern edge of the Central Asian steppe and on the verge of the AJ.tai Mountains. Zoological observation was his principal preoccupation thus far, but the many remains of large mamnals that he came across were a continual source $o f$ interest to him. His theory that, they were carried here by waters of an extraordinary flood from the south was confirmed in his mind when he cane across some remains of very large fish headsm"an ubvious proof that the sea once washed these regions." 33 TraveIing northeast from Semipalatinsk during the last week in june, tinrough Tomsk to Krasnoiarsk or the upper Enisei (Yenisey) River, Pallas contracted a case of dysentary and upon reaching the latter point (June 30) had to confine hinself to bed for several weeks, meanwhile entrustjng sokolov to scour the surrounding areas.

Krasnoiarsk was as far east as palles reached in 1771. After recovery in mid-Iuly from his ailment he spent the remainder of the year traversing the Altai Mountains to the south and west of Krasnoiarsk. Sokolov was kept plenty busy with independert ventures in the same general area as pallas, 
and Zuev, a thousand miles away, was just beginning his return journey at the end of July fron the northern coast. The yourg stident Anton valter does not sean to have figured prominently in any phase of the expedition and Pallas was shortly to assign hiv the task of accompanying Falk back to St. Petersburg, Fallas had come across palk in the Altai mining region of Barnaul late in August, bed-ridden and obviously unable to continue his expedition. In March of the following year (1772) the Falk Expedition was formally disbariaed and its members were sent to jojn Pallas in Krasnoiarsk, where he was wintering. In exchange, Valter was sent to Barnaul to aid Falk with his return.

In the Altai region of southern Siberia during the summer and autumn of 1771 Pallas carried out his usual allencompassing observations on everything from village life to plant life. To animal life, a subject he felt Johamn Gmelin had seriously neglected, he devoted much attention and neither Sokolov nor Zuev got by on their independent journeys without bringing back lots of specimens and descriptions in this regard. There were a number of factories and mining works to visit and report on in order to faithfully fulfill his instructions, but he was not overenthusiastic with this aspect of things. Pallas was not, after all, a free agent, nor were any of his expeditionary colleaguss. While obviously there were no direct controls over Pallas. activities in the fiejd, thousands of miles from st. Petersburg, 
still it was clear fron the instructions that a large part of what the sponsors (the government) wanted to know was the vealth, actual or potential, of the empire. This explains, quite naturally, the heavy concentration of expeditionary activity in the Urals by not only Fallas but by Falk, Georgi, and Lepelchin as well. Much nore interesting to Pallas in the Altai region were the mountains and geological formations themselves. It was here that he gathered much of his information which he later (1.777) formulated into an important geological treatise on mountains, ${ }^{34}$ and it was here also that he came to solidly recognize mary of the natural forces influencing geological formations. Pallas was forever ascending hills to examine their rocks and caverns, the composition of their soil, or to search for fossils embedded in their soil. Passing tinrough Barnaul and Tomsk, Pallas was back in Krasnoiarsk by mid-october for the winter.

The winter of 1771-72 was apparentiy uneventful in Krasnoiarsk, for it is largely a blank space in his travel. account. A letter that he wrote to the Academy in November mentions that he had experienced a declire in health, but that come the end of winter he would be on his way to china. 35 his writing and making preparation for this momentous last leg of his journey eastward no doubt kept him busy enough.

${ }^{34}$ Discussed below, pp. 129-132, 35 Protokoly, III. 46. 
In January Zuev rejoined him from his Arctic adventure, and Pallas was given a yast amount of new material to go through. In Pallas' eyes this your.g man had fully proved his worth to the expedition and had conpleted a formidabie task with distinction. Zuev returned with everything from a rhinoceros skull to specimens of fish from the $O b$. He also furnished valuable descriptions of the peoples who occupied the regicns of the lower ob. At length in his ow account pallas reported on this journey of Zuev's and gave a full account of its scientific results, as vell as full credit to $2 u e v .36$

Before leaving Krasnoiarsk the Pallas Expedition was enlarged by the members of Falk's disbanded sxpedition. Heading the group of four was Johann Georgi and under hin were three students from the Gymnasium, Ivar. Bykov, Stepan Kashkarev, and Mikhail Iebedev. Even though winter was still very much in evidence Pallas and Georgi set out together on March 7, 1772 on the road to Irkutsk. Pallas was anxious to see and observe the Chinese and it was one of the highlights of his travel when he finally did. Sokolov was sent out ahead in January and was to wait at Lake Baikal for pallas. Zuev was again given an independent assignment to the north, From Krasnoiarsk he was to follow the Enisei River directly north to Eniseisk, wait for better weather, and then continue

${ }^{36}$ Voyages, IV, 15-i2t. Nej.ther 2uev's nor Sokolov's material was published inderencently but was incorporated like this into Eallas' account, always with acinowledgement. 
to follow the Enisei to Mangazeia and finally to its nouth, 2 distance one-way from Krasnoiarsk of about a thousand miles. pallas was getti.ig the most out of zuev's youthful energy and taients. Kashkarev was left behind for some odd jobs. Travel to Irkutsk was by sled and fairly rapid. The distance of some 500 miles was accomplished in only a week. On the best day alone the sleds moved a distance of 131 verstes (almost 90 miles). 37 In Irkutsk Pallas stayed eight days, occupied partly by the examination of a remarkable find: a rhinoceros frozen in the ground (presumably for many centuries) with totally preserved fur and features. Actually it was discovered near Iakutsk (much farther to the north) only recently and since nobody there knew what it was its head and legs were dismembered and sent to Irkutsk for iojentification. Nobody there knew what it was either until it was made accessible to pallas upon his arrival. Pallas examined it carefully, composed a sizable treatise on his findings, and crated up the by now dried up remains to be sent to the Academy. 38

\section{3? Ibid., p. 130.}

38 Ibid., pp. 130-132. Some accounts mistakeniy claim Pallas made the orifjnal discovery in Irkutsk. But ever is, according to his ow accownt, he dic not, the event was of more than anecdotal importance. As a pioneering find his treatise on the subject "De reliquiis animalium exoticorum per Asiam borealem repertis complerentum, "liovi Commentaril. XVII (17?2), 576-606) and the remains he sent back generated a great deal of curicsity, plus a ljttle disbelief, in St. Petersiurg (Protokoly, II, $82-84$ ) and even in western Europe. According to Kanaer the treatise was Palias: largest paleor-tological contribution and the remains he sent back (skull and legs) can now be seen on display at the Zoological Museum of the Academy of sciences in Leningrad. "O Faleontologicheskikh Faibtakh P.S. Pallasa," pp. 14?-148. 
Leaving Georgi in Irkutsk for further observations of its surroundings, Pallas journeyed the short way to Lake Baikal, which was frozen and quickly crossad by sied, and two day's travel beyond found Sokolov waiting for him in Selenginsik. It was only a short way further south to the Chinese border at Kiakhta, a lively Russian trading outpost with China, where Pallas spent several days and from where he made a brief excursior into chinese territory. Obviousiy the four days spent here (April 6 to April 9) were a high point of travel for Pallas. In vivid terms he described the Chinese community opposite from Kiakhta (Maimatchin) and in equally vivid terms, as well as in great detail, described the commerce at that time passing between Russia and China. 39 The remainder of April and the months of May and June were spent by Pallas in the same generai area of Selenginsk and Kiakhta, further east of Lake Baikal to the areas around Chita and Nerchinsk, and along trie Mongolian and northwestern Manchurian border regions. For all members of the expedition this was not only the firal phase before beginning the return but also the most trying, which prepared them all the more to come home. Through May snow continved to pelt them, so fierce on one occasion that pallas had to seek refuge in an old abandoned cabin for several days. Many of their horses died from cold, but fortunately replacements were not far away. Inuncations caused by the melting snow hampered their ${ }^{39}$ Voyages, IV, $147 \mathrm{~m} 216$. 
efforts for the rest of the time. Fatigue turned to ailment and visions of return were reinforced * at the beginning of June Pallas, now at his farthest point ast on the very limits of southeastem Siberia, began his return to Selenginsk, leaving Georgi (who had since joined the main body of the expedition) and Sokolor among the Nongols to do some further exploring. A three-day excursion at the end of June back to the commercial outpost of Kiakrta ended fallas' eastarn explorations. Things ware gathered un and organized and the expedition on $\mathrm{J}: 1 \mathrm{~J}$ 3 was Krasnoiarsk-bounc, via a somewhat leisurely two-week trip to Irlutsk around Lake Baikal. Sokolov had yat to return, but Bykov was left in Selenginsk to wait for him and follow along later. Georgi, who had not stayed long with Sokolov, was dropped off in Irkutsk to pursue further investigations around Daikal.

The first three weeks of August were spent by Fallas in Krasnoiarsk (or until his spixit of adventure was regained), after which he undertook a month-long journey south, up the Enisei, coming across some Tatar tribes, several ancient tombs, and the Sayan Mounteins at the end of hic journey. Winter was upon southern Siberia by the time he returmed to Krasnoiarsik the last week in September.

Zuev, meanwhile, had rejoined Fallas in Krasnoiarsi in August after his sixmonth northerm venture, with results, Pallas thought, inferior to those of hiss irst journey to the north. He had failed to reach the extreme northern shores, and although he had done a good deal of observation around 
Mangazeia, Pallas thought it was significant only of scant mention. Sokolov's independent work in the Mongolian border region, on the other hard, held Pallas' interest to a high degree and he reported it at great length. 40 sokolov had stayed behind in this region about two or three months. Georgi's work was, of course, also important and received high praise from Pallas, but Pallas did not incorporate Georgi's material since he was not a student and was preparing his own account of the adventure. 41

The return to $\mathrm{st}$. Petersburg was much more rapid than the travels in the other direction and got off to an early start, leaving Krasnoiarsk in January 177j. Sokolov anò Bykov were sent out ahead the month before in order to arrive at the Volga in time to gather the early spring botanical treasures. Pallas himself was wasting no time. In less than six weeks (traveling by sled, of course) he rad reached the eastern side of the Urals (Cheliabinsk) and ir a few more days (at the beginning of March) was on the western side, in Kazan country. Meandering dow the Volga and traveling extensively for two months through the southerm steppe east of the Volga, Pallas arrived at Astrakhan in mid-June. Gmelin was there and Pallas saw him for the last time as he was preparing for

$$
{ }^{40} \text { Ibid.. pp. 607-662. }
$$

41 Which appeared in 1775 in two volumes: Bemerkungen einer Reise in den Jahren 1722-1774. It was subsequently greatiy enlarged. 
his second and fateful voyage to the southem Caspian. 42

Soon it was back up the Volga to Tsaritsyn (Volgcgrad), where Pallas remained the entire month of July studying the Kalmyks of the surrounding area. In August it was further up the Volga to Saratov and back down again to Tsaritsyn, where the final winter of his expedition was spent. By the time Pallas was finished on the lower. Volga this region was no doubt one of the best-studied regions of the Russian realn, owing to the fact that most other expeditions in the eight.. eenth century had passed this way as well. 43 lie left the area at the beginning of the following June (1774), after a nine-month residence which embodisd numerous excursions, making a beeline finst for Moscow and thon for St. Petersburg. St. Petersburg, to be Pallas' home for the next two decades, was attained on July 30 , to the delight of a fatigued Pallas much in need of repose.

Pallas arrived anid a mixed reception. Understandably a hero's welcome was extended, but unexpectantly it was followed by reprimand. It seems that Pallas had only recently addressed a crate containing a collection of insects to a

\section{Vorages, V, 164.}

43 Although no direct connection can be made, Pallas recognized that the Tsaritsyn area was the best site for a canal between the Don and the Volga (I bid., p. 323) and ultimately that is where it was coristructed. At the time it was projected for an area further north: in fact lowitz was conducting studies for just such a project near Kamyshin (mid-way between Tsaritsyn and Saratov) when he fell into the hands of Pugachev. 
friend in Holland. The crate was intercepted in St. Petersburg and after discussing the matter at four sessions (in April and May 17?4) the Acadrmy and its Director (Count Vladimir orlov) decided upon formally reprimanding pallas for by-passing the Aczdemy in this vay, since as his sponsor it should be the sole depository of all his collected material. Rumor had it that pallas had kept friends in Europe well supplied with Russian and Siberian objects on cther occasions, but he was caught in the act only this once. "Blamable behavior," it was termed. 44 The affair passed quickly and Pallas' status as one of the scientific exemplars of thie day was never in question.

From northwestem European Russia to southeastern Siberia, and back. Fallas had traveled a distance of about 10,000 miles, a very conservative guess not allowing for many side excursions or the added territory that his companions brought within the scope of the Pallas Expedition. But distance alone was hardly its only measure of accomplishment. 45 I.t added substantive scrutiny to the already fairly well-.traveled region of southeastern European Russia. It stretched through the less well-traveled area of southem Siberia and sent or brought back much new raw data for naturalist, geographer,

\section{4 protokoly, III, 125-130, 142-143.}

45 And it should be observed that the largest part of Siberia, east of the Erisei River and north of Lake Baikal, had not beer touched. 
and historian alike. It seems urnecessary to enumerate in any more than general fashion all of the objects that came within Pallas' grasp to collect or ail of the things that fell within his vision to describe. Significant as these appeared at the time to the scientific community, a lengthy enumeration is a guarantee of instant dozing for a historically interested person two centuries later. In recording his observations and finds, moreover, Pallas had a terdency to either overdetail or overgeneralize matters. It was usually the former; in fact when the first installment of his journal reached the Academy and was read, it was criticized for dwelling too much on "trivial" data. 46 Cuvier, in his "Éloge", agreed. Nevertheless, gathering "trivisl" information was what Pallas ( $x$ ightly) understood his task to be and was quite in keeping anyway with his encyclopedic and empiricist talents.

In scrutinizing the areas through which he journeyed Pallas adequately scanned every item that the instructions outlined he should; but in particular were his observations (1) in natural history, (2) of natural resources, and (3) of various nationalities noticably rich in contert. The first of these categories was, of course, the area of Tallas' scholarly concern and it was understandable that he should be especially concerned with plants and animals. So vast were his collections and notes in this regard that he could

$$
{ }^{46} \text { Protokoly, II, } 675 .
$$


give but a brief indication in his journai. Even so, it would have served in parts as a good text in regional zoology or botany. Ir additivi, a large appendj.- Wais added to each of the volumes enumerating his zoological and botanical discoveries. He saved the bulk of his material for later, however, intending originally that his zoological material. would be incorporated into a large iridividual work, but it was too unwieldy oven for that and hin fact it was worked out in many aricies, several monographs, and finally in his monumental three-volume synthesis of the zoology of Russia and Asia.

With the vegetable kinglom Pallas was less concerned than with the animal, but not by much. His extensive work in botany in later jears was a direer resuit of interest generated and material gathered during his expecition and not as a result of his training. In fact by his training and early work he should more properiy be categorized as cne of Europe's finst systenatic zoologists rather than as a naturai historian, which connotes an admixture of zoology, botany, geology, and a few other fields. He expanded his scientific horizons in a major way only atter coining to Russia and as a principal result of his expedition, to the detriment of zoology but to the advantage of the other infant fields he touched.

One of those other infant fields was geology. Although geology was as yet far from being developed into a methodo- 
logical science, the pertinent materinl and observations to which Palias gave attention during his expedition went a long way to pose some of the first modern questions out of which geologicai thought develoned. One opinion has it thus: "The woris of Pallas have been the basis of all later geological investigations in eastern and southern Russia, in the Ural and Altai mourtains, and ir siberia. . . his works were the means of opening up to sciencs the geological structure of the vast Russian empire."4l? In two respects this view is given substance. Firstly, from his general observations pallas conscicusiy knew that the natural struem tures of the earth were subject to both gradual and violent change. His attempts to theorize on such matters showed the infaricy of geological theory, but his attempts were liveiy minded nonetheless and at the very least stimulated interest. His view relating to the origin of large namnal remairs in Siberia has already been noted. Some of the cther rovelties of his fertile mind inciuded a theory that the Black and Caspian Seas were once united and washed a vast area of the southern steppe, 48 a theory that sand was nothing more than bits of rock, 49 and $a$ basic recognition of but an admittenly

${ }^{47}$ Karl Alfrea vor, Zittel, History of Geology aria Palaeontology, trans, by Maria M. Ogilvie-Gordon (Lonón, $1901), \mathrm{pp} .52,119$.

48 Vovages, v, $187-204$

49 Iojd. IV, 387. 
puzzled attitude as to the actus cause for the frequency of "convulsive movements of the ground" in the Lake Baikal area. 50 Secoidly, and zeide from his isrlated examples of speculation, Pallas did a great deal of more precise work that in the long run had more significance. In the Urals and in the Altai Mountains Fallas directed special attention to noting soil. composition and the existence or nonexistence of yetrifications. This gained for him a substantial amount of soil samples, rocks, and petrified organic remains to relate to the general structure and size of mountains. His ideas on mountains unfolded fuliy orily a few years after his return to St, petersburg and will be considered later in the chronoiogical place, but it is of important not that these collections and researches vere not a small part of the Pallas Expedition and resulted a few years later (1777) in a signif-. icant milestone in the history of geological thought. 51

Mors imnediate and practical knowledge was gajned

50 Ibid., pp. 394-396.

51 Interestingiy, it was his discovery of many fossils of sea. life in the southern steppe that led to his belief that one large body of water once washed this area, which was caused to roll back by the sudden appearance of the straits (the result perhaps of an sarthquake, Pallas thought), allowing the water to escape and leaving behind the individual Azov, Black, and Caspian Seas. His view was given more concrateness by his observation of the similarity of mollusks and other sea life from the Black and Caspian Seas. Using corsiderably iner techniques, a Russian geologist (S.A. Kovalevskii) in 1933 raised arew Pallas' theory substantially unaltered. A.V. Khabakov, ocherki po Istorif Geologomazyedochnykh Znanii y Rossii (Moscow, 1950), p. 134. 
through Pallas' efforts with regard to the natural resources of Russia. Pallas personally had a low scientific appreciation for ninerology and the like, but he was cbezient to his instructions and devoted considerabie time to investigating the actual and potential wealth of Russia's mineral regions. Palk, Georgi, and Jepekhin devoted no less. But enough was anough and on Pallas' initiative the expeditions had extended their scope much beyond the Urals. Minerals, mines, mountain factories, and salt works were not the whole of Pallas' "practical" observations; he noted as well f'orest preserves and a rich supply of material was gathered on economic and commercial factors of remote inhabited regions within the Russian Empire. 52

Near Krasnoiarsk in October 1772, while climbing around some hills, Pallas came upon one of his more celebrated finds: a large mass of what appeared to be iron lying completely open to view. He had an idea that it was detached from a soft rock, fallen to earth in effervescence, and formed there by the forces of nature. But of its celestial origin Fallas picked up from the local legend and beyond its being one of nature's peculiarities he could not clearly conceive. 53 pallas

52 A point given particular stress in $\forall$.A. Golobuckij, "Die 'Reise' von Pallas als Quelle für das Studium der sozial-ökonomischen Verhältnisse in Russland, " in Lomonosov, Schlözer, Pallas, po. $258 \mathrm{3}-262$.

53 voyages, IV, 595-604. 
collected a large sample for the Academy rasseum and it was subsequently recognized as $\equiv$ meteorite and named after him (Pallasite).

of course palias can not be claimed to have been a geologist, a paleontologist, a minerologist, or an expert in economics, nor even the founder of these studies. He never once used these terms to describe what he was doing. In the parlarce of the day Pallas would have classified himself a doctor by training, 54 a zoologist by interest, and a botanist by its hand-in-glove relationship to $20010 \mathrm{gy}$. In Russia he was the Academy's Professor of Natural History and as such was being paid to engage in observation of a little bit of everything. He parformed to the utnost and earned his keep with more distinction and more results than nost on the Academy payroll. In some cases he went far beyond the surface observation in diverse fields (which is usually associated with eighteenth-century men of science who were classed as naturalists or natural historians) and developed a deep intellectual interest in certain fielas aside from zoology and botany. This was the case with Pallas' zeal for scratching out fossil and other remains and associating these finds with

54 on more than ole occasion during his expedition Pallas wa able to out his professional training to practical use. A representative instance was his diagnosis to a particular insect of ar epidenic disease in the Urals that was afflicting both antmais and humans, for which he recommended burning the fatally afflicted animals as a precautionary measure, while spreading the word of what precisely to guard egainst. Voyages, II, 438-444. 
lerger theories of the earth's structure and development. Below the surface of the ground, Pallas was vividly aware, lay "the archives of nature." 55

This was the case also with Pallas' work among the, nationalities that he came across, and oftentimes went out of his way to come across. Probably the most thoroughly studied by Pallas were the Kalnyks of the lower Volga region and the Mongols of the east. On these and many other pocples 56 Pallas collected an impressive amount of information, language specimens, and objects of antiquity, most of which he saved for a work that he was already projecting and later got around to writing on the Mongol peoples. 57 Native peoples were not always the object of stidy; rather in some cases the object of fear. Friendly native guides were recruited along the way partly for guidance but partly also for protection. Palias' largest such entourage was a group of twenty Don Cossacks who accompanied him through the southern Russian steppe in 1774 to guard against potentially hostile Turkic

55"orservations sur la Formation des Montagnes et les Uhargemeñ arrivés au Globe, particuilerenent à l'ésard de I'Empire de Russie," Acta Acaoemiae Scientiaxum Imperialis Detropulitanae, I, pt. I (1777), sect. I, 46.

${ }^{56}$ some were mentioned anve, n. 83, others included the Chuvash, Bulgars, Finns, and some newly established German colonies along the Volga.

57 In two volumes, oublished iwenty-five years apart: Sammlungen historischen Nachrichten über die Morgol ischer Vólkerschaften $(1776,1501)$. 
nomad3. In any case, Pallas became very familiar with the peoples of eastern Russia and southern Siberia and his work in this regard, while lacking in precise concepts and methods of later ethnographers, scared far beyond nere casuai notice of surface characteristics. Zuev's travels in the north contributed, among other things, valuable cbservations on northem inhabitants (Samoyeds and Ostiaks) to add a little frosting to the Pallas Expedition's significant accurnilation of ethnic data.

All of this leaves aside the features of lesser significance of the Pallas Expedition, so far as specific content is concerned, that when totalled together, nevertheless, add up to complete the shape of its general significance. Areas were mapped, geograpiical features brought into focus, toms and villages were described, in short, an area (southern Siberia) at best vaguely known becarne somevhat better know not only in general geographical and physical features but also in its more specific natural and human make-up. But of course the path that fallas and his students cut across Siberia tock in only a smald part of the torritory itself, albeit the heart of it. Nor was Pallas a pioneering trail blazer. He knew, at least in a general way, where he was going and what was up ahead of him. Most of the trails palias followed had been biazed by Russians well over a century before. Most of the towns he came upon were thus wellestablished Russian outposts where he could obtain lodging, 
provisions, and fresh horses. However, naturalists or cartographers were not a common sight in Torask, Krasnoiarsk, or Irkutsk to reiay enligisiening knowledge if these regions back to the seat of Russian government. Fallas' task was to bring the area, in all possible aspects, into careful scrutiny and to record the fruit of scrutiny onto the printed page. A mediocrity in the place of Fallas would have rendered the event to footnote status for future generations of historians. The Pallas Expedition, after all, was of shorter duration and more restricted scope than the Great Northerm Expedition three decades earlier. And under a less assertive porsonality it woula no doubt have adhered to the originaily planned scope, which would have holted its eastward progress at the Urais and shortened its liltimate duration by two years. In any. case, it would have become in historical perspactive more nearly equated to the other Acadernic expeditions of this pericd (which is not to belittle their individual or aggregate significance) rather tran having become tha center of expe-. ditionary achievement and the focus from which the other enterprises of $1768-1774$ must $12 \mathrm{~g}$ in grandeur. 58

Looking at the expeditions of $1768-1774$ (with greatest

${ }^{58}$ To some observers the Paljas Expedition is synonymous with the Academic Expeditions of $1768-1774$. This is a false estimate and may be due to the fact that the other expeditions are not generally lnown as much as to the greater significance and scope of the Pallas Expedition in comparison with the others. In this section I have provided at least a little clarity on this matter. 
attention on that of Pallas) in a general way two featurea of great significance should be noted: the groundworis that they laid for more detailsd irvestigatior of the ratural conditions of European and Asiatic Russia and the basis they provided for the advance of natural science in an academic way; and the apprenticeship of an important group of Russian students, some of whom later established brilliant careers ard sometring of an independent Russiar renaissance in the field of natural history.

The landmark represented by these expeditions was not in expediticnary activity alone, nor in scientific activity alone, but in the combination wich may be termed scientific exploration. They derive this appellation by virtue of the near total effort expended by the Academy in the sponsorship of them, by virtue of the rigorous demands placed on the participants to scrutinize not only extensively but with care and in depth, and by virtue of the quality of people with whon these demands were entrusted. Never before had so much territory been covered in so thorough a manner by so many top-notch observers with a scientific turn of mind all at the same time. In the Acadeny's history the period 1768-17?4, to reduce it to a phrase, represented the ascendency of interest in knowing what preciseiy was contained within the Russian realm. For the moment all other Acacemic endeavors were eclipsed; in point of fact, the members of the Academy who remained in St. Fetersburg engaged in other work during 
these years were few in number. The kind and extent of material gathered, together with the man (Palias) who did more subsequently than any other to make systenatic sense of it, furthermore, gave a solid foundation to an area of study (natural history) that had as yet achieved little in the way of parity with the much more strongly rooted tradition in the Academy in mathematics and its related fields. Hereafter natural history had as distinguished a representation in St. Petersburg as in London or Paris or Berlin, and the point should not be lost that the deeds performed from 1768 to 1774 by the explorers from st. Petersburg did not remain foreign to other Eliropean centers of science. Inceed for those who cared to know what animals, vegetation, terrain, minerals, native customs, or other curiosities prevailed in obscure parts of the world the event was one of European importance. Pallas' travel account went through several German and French editions, was abridged into English, not to mention being translated into Russian and somewhat later into Italian. 59 And the only travel account to result from these expeditions which was written in Russian (that of Lepeknin) was given an immediate rendering into German.

Much of the ultimate credit for this era of exploration and scientific discovery must go to the Empress Catherine II, who forged the atmosphere within which advances in science and exploration were given every encouragement and who set

${ }^{59}$ see above, p. 73. 
in motion the whoels of action that would bring to st. Petersburg an array of talented men of science who gave substance to the enlighter.ed desire for leailing to ilourish. Regaraing exploration, Catherine has a strong claim to have motivated an event every bit as significant as any carried out in Russia in the eighteenth century. Whereas Peter I earlier in the century motivated the epic attempts to learn of the extremities of empire, ${ }^{60}$ Catherine motivated the series of expeditions whose task it was to bring the interior conaltions and nature of empire into clearer focus. Moreover, no subsequent single Academic effort superseded the combined effort of 1768-1774 in its goals, with the possible exception of the Siberian expeditions begun in 1843 and presided over by Alexander Middendorff.

All of the individuals who led these expeditions were newcomers to the Academy, assembled for the immediate yurpose on which they soon were to set out. When the idea formed to sponsor a general expeditionary enterprise the Academy had no qualifjed observers in the natural sciences. The assemblage of persons whose profession was in the natural sciences, at the center of which was Pallas, for this purpose marked in essence not only. the Academy's determination to supply a talented core of experts to survey the land of Russia but also a revived emphasis on the nomathematical and nonexper-

60 Since the Great Northern Expedition had its origin ir the uncertainties which surrounded the First bering Expedition (1725-1730), wich feter personally inspired, this reference is meant to reite to both. 
imental sciences. The solid grounding of natural science in Russia foliowed fron the expeditions of 1768-1774. The expeditions.cost the Acadenty the further servics of two nembers in this field (Falk and Gmelin) but the emphasis should fall rather or the unparalleled boon to natural science, not to mention the simple fact of geographical knowledge, represented by the men who participated in this venture, their coliections which filled the museum with objects for every interest, and their observations collected into hefty volumes. Pallas, whose post-expeditionary work and influence radiated the farthest, was to be around for a long time to come; his career will shortly be the center of attention. Güldenstädt was around for a few years, but did not overly concern himself with follow-up work to his expedition. He was more interested in his chosen profession (that of medicine) and, as a matter of fact, exposed himself to a'lethal fever in treating afflicted patients and died in St. Petersburg in 1781. 61 Georgi, like Pallas, was around for $a$ long time as a distinguished member of the Academy, and although he filled the chair in chemistry, the list of his published work ${ }^{62}$ reveals that perhaps more of his time was spent building upon the observations and material he had gained during his travels rather than in the laboratory. The expeditionary era of 1768-1774 served another $61_{\text {Russki B Bjograficheskii Slovar, }} \mathrm{V}, 189$. 62 Ibid., IV, 427-428. 
important function that deserves emphasis: it served as a training ground for Russians and a chance for them to shine. Four of them did shine ard proved, as Krasheninninov proved three decades eariier, that Russian students were capable of keeping pace with European standards in natural history, even though as yet not very many of them. These individuals went on to become academicians in their own right, contributing substantially to the Acea emy'is remarkable browth in the area of the natural coiences in the final third of the eighteenth century, and also served to emphasize that Russia had finally come up with more than an isolated native spckesman in this field of science. I,epekhin, as already mentioned, had led his own expedition, 53 having just previously completed his education abroad and accepted into the Academy as an adjunct in natural history. A year older but without the stature of Pallas, Lepekhin was nevertheless possessed of axceptional talents and he was without question the dean of native Russian natural scientists up until his death in 1802. His efforts were wide-ranging, which distracted from, but diu not rait, his purely academic work. He was, for instance, one of the original and very important nembers of the Russian Academy (founded in 1783) and was named as its first permanent secretary, in addition to being in charge of the Academy's

${ }^{6} 3_{\text {Lepekhin was the only Russian to lead an expeditionary }}$ contingent, uniess one considers Rychkov, who after separating from Pallas did some independent expioration in 1771-1772 west of the Urais. 
botanical gardens, having a hand in the administration of the Academic Gymnasium, ard being loaded down, like other Russian academicians, with translating activity. 64

Each of the expeditionary detachments included in its make-up three Russian stuclents of the Gymnasium. Three of these students--0zeretskovskii, Sokolov, and Zuev--emerged as exceptional and after their return and completion of their university education abroad became full-fledged academicians in the 1730 's as well as memoers of the Russian Academy (except for Zuew). They were all members of the Academy in the field of natural history and like their older Russian colleague, Lepekhin, were productive ana wholly proficient scholars, but were distracted to a great extent from purely academic work by the assuredly more important tasks of modernizing their native tongue to bring it up to date with modern scjence, by translating inportant worksi by teaching; and in other ways providing some of the nuts and bolts for the peretration on a wider scale of European science into Russian intellectual life, zuev, the youngest member to participate in the expeditions and apparently of precocious mind, provided Russian students with the first natural history

64 substantial accounis ot Iepekhiri are contained in two works: N.G. Fradkin, Akademik I.I. Iepekhin i Ego puteshestviia co Rossii y $1768-1273 \mathrm{gg}$. Academician I. I. Iepekhir and His mravels in Russia in 1768-1773] (2nd ed.: Moscow, 1953); M. I. Sukhom inov, Istoria Rossi iskoi Akademii [History of the Russian Acadeny] (8 vols., St. Petersburg. 1874-1887), II, 157-299. 
textbook written in Russian. 65 Neither zuev (d. 1794) nor Sokolov (d. 1795) enjoyed long careers, in contrast to Ozeretskovskii (1. 2827) who became a sixture ir. St. Petersburg's learred halls but who iong outilved his associates as well as the ascendant era in natural science that pasied with them. Recalling the years at the turn of the century, Nikolai Grech thought Ozeretskovskii was the foremost Russian scholar in the Acadeny despite nis less desirable qualities of being "cantankerous, slanderous, foul-mouthed and a dipsomaniac." 66 These then were the men of 1768-1774 who during those yoars contributed to an anterprise that yielded an unprecedented amount of information and matexial and who for a quarter-century afterwards formed the group of men behind what may be termed, conservatively, a period of inspired advance in Russian natural science. The inspiration was provided by Pallas, around whom these men grouped and recognized as their mentor. Not all of them followed the same lights as Pallas, nor produced to the same degree. Sokolov became more closely the student of Georgi, and ozeretskovskii was more attached to Lepekhin. Zuev, the only Russian academician. of this group not simultanecusly affiliated with the Russian

$65_{A}$ two-volume wori published in 1787 (Nawhertanie Estestvennoi Istorii [Outline of Natural History]) to which Fallas made some addifions and acclaimed as a mork superior to any similar text of its day.

66 "Zapiski N.I. Grecha," [Memoirs of N.I. Grech]. Russki1 Arihiv, XI (i373), 710-711. Grech (i78?-1867) was a Russian jourral ist and writer. 
Academy, actuali.y became the closest student of Pallas, translated several of his important works into Russian, and followed Pallas in sonsidsring hirself chiefly a zoologist. 67 Broadiy speaking, however, the academic endeavors of this group followed in the bmoad swath cut by Pallas through the thjckets of Russia's unknown natural conditions. Like Fallas in the 1790's, Zuev (in 1781-1782) and ozeretskovskii (in 1785 and in 1805) revived their expeditionary spirit later to undertake small-scale expeditions. With the fading away of Pallas from st. Petersburg to the Crimea and the death of those around him by the beginning years of the nineteenth century, the Academy was hard pressed to maintain men of equal capacity in the natural sciences. Naturalily enough (also taking into consideration the disruptive nature of this period) decline set in which was in general true of the Academy as a whole. The field of endeavor to which Pallas devoted his life was not substantially advanced until Karl von Baer was acquired by the Academy in the early $1830^{\circ} \mathrm{s}$. The overall importance of the Palias Expeditior, in light of the preceding comments, is not far to seek. Some of its specific features have been urifolded, but given the nature of the material from which I have drawn, any account

${ }^{67}$ Even though $h$ is career was fairly brief, zuev produced an enormous amount of work of high quality. mostly in articles, and primarily pertaining to zoology. His biographer is R.E. Raikov, Akademik Vasilii Zuev, Ego Zhizn i. Trudy [Academician Vasilii Zuev, His Life and Works] (irioscow-Leningrad, 1955). 
would be incomplete. In other woris, Pallas' travel account and his communeations to the Acadsiny are only partial indication of the seriousncss with which he rlunged into the task of bringing to light matters that would explain some of the nature and make-up of hinterland Russia. Off and on, Pallas spent the rest of his life in further detailing and working out the material he had gathered from 1768 to 1774 ; thus to a great extent, it can be accurately summarized, his work after 1774 represented an unfolding of the full and diverse fruit of his expedition, which in turn unfolded before the scientific world a large body of completely new material and new ways of looking at the old. This was one of the fundamental factors that went into shaping an era of lively advance in. science in Russia during the reign of Catherine II. 


\section{CHAPTER $\vee$}

\section{PALIAS AS ACADEMICIAN IN ST. FETERSBURG, 1774-1793}

From $17 ? 4$ to 1793 Pallas lived and worked in st. Petersburg as a member (an internationally known and respected member) of the Academy of Sciencas. The second section of the paper attempted to set down. some pertinent background to the Russian surroundings in which he found himself, and it was stated that the final third of the ejehteonth century was a period of solid advance in the growth o $\vec{i}$ science in Russia, in contrast to the period immediately preceding and the period inmediately following. It would be useful to return briefly to that theme in order to emphasize a few besic poirts and to introduce a few cautions.

It has been cogently and coloxfuliy stated that "science in Russia . . stemsed from a foreign tradition anä was somewhat axin to a luxuriant flower blossoming on the surface of a stagrant pool of ignorance and illiteracy." ${ }^{1}$ Equally cogent, if seemingly contradictory, is the view that "during the second half of the eighteenth century, scientific thought spillad over the rigid confiries of the Acaderny of sciences to wash a vast area of Russian culture." 2 While these views

1M.T, Florinsky, Russia: A Histony and an Interpretation (New York, 1953), II, 1048-1049.

${ }^{2}$ Vucinich, Sciencs ir Russien Culture, p. 181. 
both address themselves to a broader aspect, of Russian history than is being attempted here, thsy errress matters that striks at the heart of what in inpcintent to understand abolit the era of science and the overall atmosphere in Russia in which Pallas participated.

Assurediy, the Academy represented a foreign and luxuriant flower that at no time in the eighteenth century could have been nourished from the strata of Ruscian socisty; but also assuredly, the gains registered in the Academy's status and output after 1768 vere marked over the previous forty years. The advance in the status, the quality, and thus tho output of the Academy was foreshadowed by official wiliningness to recognize the Academy's plight and by the desire to make of the Acadeny a prestigous symbol of the Russian state. Without official patronage the Academy would have amounted to little in Russia and thus the role of Catherine II was fundamental. Monetary support and structural reforms, the two basic ground-level ingredients to Academjc upsurge, were her gifts to the Academy which resulted in the further stimilus to scientific advance provided by EuJer's return and the Pallas-led expeditions of 1768-1774. It is a striking fact of the Acadeny's history that from Euler's return in 1766 to the end of the century only six of the thirty-seven persons adnitted to membership in the Acadamy curing that time voluntarily quit.--and none of major consequence. 3

3 Modzaievski, spisok Chienov, pp. $24-31$. 
Another fact of inportance in characterizing the Academic atmosphere during Palias' residence in St. Petersburg is the fact of a noticeably greater Fussian participation in Russia's intellectual activity. When pallas entersa the Acadeny in 1767 there were six active Russian members; when he departed on his second expedition in 1793 there were eleven, 4 about half of the total membership. The trend during this quartercentury was unmistakables scientific activjty in Russia was coming to include more Russians. The increased number of Russian-born Academy members is a basic revealing indication of this trend, which, as might be expected, had the affect of increasing native Russian participation in Academic ariairs vis-à-vis that of foreigners. This should not cloud the fact that foreign influence and ideas even at the end of the century was the predominant factor in the Iife of the Academy, which fact shouid also not cloud or underestimate the growth of Russian participation in scientific activity in the final third of the eighteenth century. Symbolizing the fact of increased Russian participation in the formerly all-foreign Academy of sciences, in the $1790^{\circ}$ 's for the first time treatises in Russian hegan to appear in the Acadeny's journal (Nova Acta) alongside the contributions of foreign members written in a foreign language.

${ }^{4}$ Aleksei Protasoy, Simeon Kotelnikov, Stepan Rumovskii, Ivan Lepekhin, Petr Inokhodtsev, Nikolai ozeretskovskii, Vasilii Zuev, Nixita Sokolov, Aleksei Kononov, Vasilii Severgin, and Iakov Zakharov. 
There were other sigras a.e well that hand in hand with the Academy of Scjences' general lipsurge during Catherine II's reign went a brozdening of Russian intellectual aotivity. The most inportant sign, perhaps, was the founding of the Russian Acadeny in 1783, an all-Russjan institution which signaled Russia's readiness to come to grips with the problem of systematically updating the Russian language. Russian academicians during this period, if not world-shaking thinkers, were a busy group, Being obligated to divide their time between the Academy of Sciences and the Russian Acaderny, they were more versatile than profound, But because of their versatijity they stand in historical perspective as the group of men responsible for making deep Russian inroads into the foreign-dominated intellestual tradition in Russia, while at the same time transmitting European science beyond the confines of the Academy. This was accomplished in several ways: by an increasing agenda of public lectures delivered by academicians, which after 1784, at the instigation of Princess Dashkova, began to be delivered for the fjirst time in Russian by native Russians and were free of charge: ${ }^{5}$ by Russian periodical publications of a scientific nature which increased in number and, it was hoped, in circulation; by an increasing

5"Direktor Akacemii Nauis Kniaginia Ekaterina Romanova Dashkova. Doklady Gosudaryne Imperatrjise Ekaterine vtoroi," Chteniia $y$ moratorskom obshchestve Istorij..., IX (Jan,-March, $\left.186^{7}\right)$, sect. $V, 15-16$; The Meroirs of Princess Dashikov, pp. 211-212. 
amount of original scientific literature being written in Russian, which was natural enough since the number of Russian academicians was also jocreasing and $\mathrm{by}_{\mathrm{a}} \mathrm{f} \in \mathrm{everish}$ translation activity which brought within reach of Russian readers a wide selection of ideas and knowledge. 6

These signs of Russian scientific advance were smaIl or large depending on the angle of perspective. Against the background of Russian achievements in science beginning around the mid-nineteenth century they were paltry. Against the background of what preceded (the proper line of perspective) they represented a large advance in Russian intellectual iffe. One serious flaw, however, remained, Russian educational institutions were only about one stage removed from being nonexistent. Catherine II had wantsd the flower of scientific life in her realm while by-passing the buciding stage, and although some educational ideas and reforms were put into practice during her reign, educational advance is not one of the major landmarks of her rej.gn. $7^{\circ}$ The Academic upsurge and

${ }^{6}$ After 1783 the central translation activity was organized within the Russian Academy, which took over the functions of the socisty for the Translation of Foreign Books (Sobranie, staraiushcheesia o perevode inostrannykh knig). This society existed from 1768 to 1783 and issued no less than 173 volumes of translated material, including philosophical anc soielitiric classics as weli as modern works. Descartes, Bacor, Nevton, For instance, were known in Russian, so were some works of the French philosophes and nany articles from the French Encyclopedie. Zubov, Istoriografiia, pp. 52-55.

7 For general information on education policy under Catherine IJ see Nicholas Fens. History of Russian 
the increased Russian participation in Academic life in Russia were very real but also very shallow. This shallowness provides part of the explanation for the failure to keep the scientific momentum that wes built in the last third of the eighteenth century going beyond the death or departure of the immediate contributors to that momentum and the introduction of a few adverse policies.

Catherine's Iiberal and reformist credentials have been pretty seriously and effectively intruded upon by scholars, but her political state of mind is beside the point in establishing her role as patroness of Academic progress. Catherine desired that an Academy of Sciences be azsociated with the Russian state, and because it was apolitjcal, received support and encouragement for the greatest part of her reign. While Alexander Radishchev was being compelled to cool his heels in Siberia, Pallas was being heaped with honors and rewards. (The Russian government tolerated the free-thinking Radishchev about as much as the French government had earlier tolerated Voltaire and Rousseau; it tolerated Pugachev and his gang about ats much as the English government tolerated Irish or, better yet, American rebels.) The fact that all plans for Academic autonony anvounced in 1766 were scrapped aitogether in 1783 seems to have created Educailonal pojicy (1701-1912) (New York, 1964), pp. 17-32; W.H.E. Johnson, Russia's Educational Heritage (Pittsburgh, 1950), pp. 43-62. 
no stir at all among the academicians. They were woxking hard, confident of monetary support, life in St. Petersburg was not dissimilar from any busy Europear city; the empress who resided there was penpai with European Iuminaries, and the Russian members were newly excited to see Catherine's and Princess Dashlova's creation, the Russian Academy, off to a good start. When liberal principles departed, patronage remained. Some of Pallas' basic scholarly work during his two decades in St. Petersburg was commissioned directly by Catherine, whom he was privileged to know personally and from whom he received numerous ravors, in turn for work well done, of course. Right up to the end of Catherine's reign, reaction notwithstanding, Pallas, to cite but one instance, was gen.. erously patronized. Catherine's last gift to Pallas was the sum of 10,000 rubles, given in 1795, and two estates near Simferopol (in addition to a house in Simferopol) in the Crimea on which he was to work in semi-retirement. ${ }^{8}$ His private natural history collection netted hin ancther 20,000 rubles from Catherine without having to part with i.t (for inclusion in the Academic museum) until he wanted.

Iife in Russia was not uncomfortable for Pallas, nor for others of his caliker. The generosity bestowed upon Pallas suggests that for politically docile men of science st. Petersburg was still at the end of the century a very

${ }^{8}$ V. Marakuev, Petr Simon Pallas, Ego Zhizn, Uchenye Trudy i Puteshestviia (Moscow, 1877), pp. $20-21$. 
good piace to mare eng's mark, as it had been since Pallas first arrived. Purthermore, for ar ambitious naturalist, Russia was attractive because of its weal tii of witouched and unknown things and the limitiess opportunities that were available for new discoveries. Pallas' career in Russia capitalized on just this elenent, and at a time when the Academic atmosphere was $v e r y$ favorable in St. Eetersburg, or at laast had vastly inproved over what it enrlier had been. Pailas' work was never interfered with, except as new responsibilities continually made demands on his time. He carried on freely a correspondence and kept up a lively exchange of plants, arimals, rocks, and other objects with cclieagues abroad. Through the years from 1774 to 1793 his talents earned him prestige with his colleagues, favor with the government, suitable rewards for his efforts, and an influential voice in important Acadenic matters.

In 1801 an Englishman, Edward Clarke, visited Palias in Simferopol and could not understand what kept a man of Pallas' reputation affiliated with a country he himself saw as politically and socially barbaric. It was a questicn that occurred to others as weil. Another Englishman, several decades later, bluntly referred to paj.las in Russia as a "learned and ingenious slave." 9 Clarke tried to porsuade Pallas to leave. Pallas took no heed. "he left him," clarke

9 James Augustus st, Jom, The jives of Celebrated Traveliers, vol. III (New York, 1859i, p.68. 
remarked in a tone with a shade of sarcasm, "determined to pass the remnant of his days in cuitivating vineyards anong the rocks upon the south coast of the [Crimean] peninsula."10 Clarke failed to see the entire thrust and atmosphere of Pallas' career. For the most part, Pallas, and the Academy in general, were removed from the political and backward aspects of Russian life and in turn were not intruded upon by these situations, except as they were manifested in severe censorship regulations in the second half of the $1790^{\prime} \mathrm{s}$. In favorable and profitable circumstances, Pallas in Russia existed in a virtually untapped storchouse of material where pioneering scientific achievement existad in abundance. From the moment he set foot on Russian soil, Pallas set for himself the long-range goal (a.lthough not as long as it turned out) of compiling for European science a comprehensive studiy of the zoology of Russia. ${ }^{11}$ Having had the opportunity to investigate a large section of the Russian Empire at first hand, $h$ is interests broadened and his career as academician in Russia vecame almost cluttered with a number of shorterrange goals; but whethar relative to zoology, botany, or some other field, his scholarly productions were singly of the nature to repcrt hitherto hidden lnowladge. With so much

\footnotetext{
10 Travels to Russia, Tartary, and Turkey (reprint ed. I New York, 1970), pp. 370-371.

${ }^{11}$ so he stated in the preface to his Zoographia Rosso-Asiatica.
} 
of that available for investigation in Russia, Pallas came to realize that the St. Petersburg Acadeny was a naturalist's haven. Arctic life, dezert life, forest life, steppe life, river Jife, sea Iife, mountain life, even ancient life preserved in the frozen ground were all available within one realm and added up to a greater variety of organic specimens. not to mention the equal abundance of inorganic specimens, than any of Pallas' European friends and colleagues had the pleasure to have within their reach. More than once Pallas spoke of Russia as his fully adopted second homeland and expressed his enthusiasm for the wealth of new material with which he was able to occupy himself there. ${ }^{12}$ His decision to wndertake another expeditior in 1793 and $h i s$ subsequert request in 1795 to be allowed to live in semi-retirement in the Crimea were made for reasons $c f$ health and to get away from what he called the "incessant bustie" and "artificial society" of St. Petersburg. 13

The motives for Pallas' long residence in Russia were not all reasors of scholarly opportunj.ties and he was by no means absolutely wedded to Russia or to the St. Petersburg Acadeny. Naturally enough, he sometimes expressed a longing

12 Fallas quoted un this point in E. Streseman, "Leben und Werk von Peter Simon Fallas," p. 252; F. Hoffmann, "Die Briefe von Pallas an G.F. Müllex," p. 314.

13 Travelis through the southem Provinces of the Russian Empire in the Years 1793 and 1704 . trans. by Francis W. Blagdon (Londcr, 1802-1803), I, 3 . 
to return to his German surroundings, but was prevented from doing so, as he expressed to Pennart in 1777 , because of "circumstances of fortune." 14 Pallas vas not nevessariiy a fortune hunter (certainly not in the way characterized by Princess Dashkova that "ho lacked all principles and morals, he was vicious, he was out for personal advantage ..."15), but he had no aversion either for monetary gain. What he really desired was an independent scholarly career which only independent means could allow. If he stayed in Rusisia in hopes of acquiring independent means, he stayed there also because the opportunity for pioneering achievement existed in abundance and the st. Petersburg Acadeliy was as congenial and prestigious an atmosphere as any for furthering scholarly goals. In any event, when he left St. Petersburg in 1793 and in 1795 acquired the means to live in semi-retirement, his request to reside in the Crimea while maintaining his affiliation with the St. Petersburg Academy did not reflect the decision of a man itching to leave Russia as soon as his desire for. "personal advantage" had been gratified or for

14 Urness, ed., Ietters, p. 14. In 1778 Pallas expressed to Pennant that ". I expect every year to leave this country" ( $p, 29)$, and in 1781 wrote again to pennant in the same vein but considered it out of the question "as iong as want or an independent, and sufficielat fortune will keep me in this Country." (p, 154).

15 The Memoirs of Princess Dashkov, p. 221. Steming from a basic perscnaitity clash and several issues, which will be related later in this section, there was no love between pailas and Princess Dashkova as the Academy's Director. 
reasons Edward Clarke might have thought natural. By that time his entire adult career had been devoted to one aspect or another of investigeting the natural corditions of Russia and Siberia and he desired cniy the serenity to complete and consoiidate his basic work, By that tine also he was the greatest living authority on Russia's natural (and even some historical) features and had etched his name next to the greatest and most productive natural scientists of the eighteenth century.

Following Pallas' return to st. Petersburg in the sumner of 1774 it was business as usual, but busier than usual, for him in the Academy--aiter he had answered for trying to sneak a package of bugs to a friend in Holland, that is. According to the 1747 statutes, still in effect, the academiciars were to function as researchers and teachers. The Academic University, however, was not in effective operation, so Pallas had no teaching duties in that regard. He was not involved in the operation of the Academic Cymnasium and the Russian students who had accompanied him on the expedition had gone abroad for five years to receive their university trainjng. Thus as a pure researcher Palias' specified duties, which applied to all academicians, were to work to advarice the knowledge in his science, to publish the result of his labors, and to keep abreast of ail other work being done in the same field (in order to enrich himself, obviously, and so that if 
another piece of work was deemea worthy it could be brought to the attention of others for transiation and publication into Russian).

The business and discussicis of the Academy were conaucted in the triweekly general Acatemic sessjons (they were usually less frequent than triweokly), at which pallas, when it was his turn, would talk about what he was doing, what he was going to do, read his latest piece of research, or raise any matter for discussion relative to his activities and concerns in the Acadeny. Usually his appearances in these sessions were for the purpose of presenting his latest treatise, which had to receive general approval before it could be included in the next volume of the Acadeny's journal, and to report on tis larger works in progress, upcoming, or completed. If the work generated general interest it was read, in manuscript, at length. Such was the case wi.th his work on the Mongol peoples, ${ }^{16}$ the tirst volume of which Pallas read at twelve sessions in $1776^{17}$ and the second volune of which he read at intervals as parts were completed.

Pallas' only other statutory obligation was to participate in triannual public assemblies. These were gala affairs, actually called less ofton than three times a year (usually only once a year), which usually saw in attendance the

$$
\begin{aligned}
& { }^{16} \text { See above, p. } 104 . \\
& { }^{17} \text { Protokolv, III, } 234 \mathrm{ff} .
\end{aligned}
$$


empress, various state dignitaries, and a foreign dignitary or two. This was Academic open house (open, as a matter of fact, to anyone who wiched to attend) anc an event planned well. in advance which featured an opening speech by the Director, several academicians who read a specifically prepared piece of their work, and various exhibits.

In the first few years after raturning from his expedition, Pallas' turn twice came around to be the central speaker at the public assembly, in 1777 and in 1780 . The occasions called for something scholarly but not too technical E.s to be above or boring to the audience in attendance. Thus, in 1777, his "observations sur la Formation des Mo:tagnes" and, in 1780, his "Memoire sur la Variation des Animaux." These two short works of Fallas have received nearly as much attention by those who have written on him as his larger works, but have never been explained. They were in the realn of theory; Sallas was not a theoretician. They were totally out of character with the flow of his work before or after, and especially since the immediate aftermath of his expedition when, after having already described the general and outstanding features of it in his travel account, he was working primarily on putting into print the zoological and botanical technicalities of his observations. Pallas, as a matter of fact, declared in his "Memoire" that he planned a follow-up work on the variation of animals, but it never appeared, at least was rever published. The best explanation 
for the appearance of these two works seems to be in the occasion for which they were written.

It was too bad that Pallas did not avail rimself of other opportunities to let his thoughts come out over all the detail in his mind. As these two essays displayed, pajlas was ably equipped to theorize on science based on a full arsenal of facts fully digested, compared, and weighed. Pallas "Observations" was read before a host of dignitaries, including the King of Sweden. The heart of Pallas presentation was his treatment of the formation, structure, and composition of mountain chains, which he cautioned his audience were only one manifestation of a slowly and complexly formed easth about which very little was actually known because of the many factors and long time-span involved. Cautioning again against Buffon's ambitious theories on the structure of the earth, Pallas took his iisteners through. his ow researches in the Ural and Altai Mouritains, differentiating three orders of mountains which differed in com-position, size, and age. The highest parts, the core, of the great mountain chains were composed of granite, were the oldest, and were anterior to land life and to the revealing of all other land features, which came later as a result of forces at work beneath the sea. Volcanic force was Pallas' explanation for the later upheaval of the differently composed and smaller second ard third-order mountains. In some detail, Pallas went through the composition and organic 
remains he had observed in these structures, arriving at a clear estimate of the relation between the center of a mountain chain and the progressively smaller and younger outer layers. Pallas jealt with other matters and this sketch does not do justice to the evidence he cited or the clear conceptions he had, for instance, of volcanic activity, decomposition of elements, deposits on land left by the sea, and a basic sense that his age, for all of its bold advances, had not even scratched the first layer of the earth's story. In closing, he warned his audience not to be taken in by single-cause explanations for the present structures of the earth and that there was no such thing as constancy in natural forces.

Cuvier thought this essay gave birth to all that followed in the geology of his day (de Saussure, Deluc, Werner), 18 others have provided better perspective. In his theory of mountain chains and the time sequence involved in their formation, Palias was the first European off the blocks. His evidence was solid, systematically acquirec, and his ideas were clear. Basically, in fact, Pallas had a clear idea of geological sequence and some of the evidence available in the ground that could reveal at least the outlines of the earth's development. In Russia his role in geclogy was very great since his researches dealt with Russian soil and could thus readily be advanced. Regardirg Europe, although he fore- 
shadowed systematic work in geology, others quickly surpassed him who were close on his heels anyway and who were more willing than Pallas to take the earth's story entirely out of the hands of a creator. 19

Pailas was not a geologist and did not pursue much beyond a descriptive level his investigation of the earth. This was not intellectual cowardice on the part of Pallas, but rather a part of his scientific conviction. Seience was advanced, he believed, when evidence was presented, not when somebody with a gifted pen said something protty. His "Observations" was a challenge to Buffon; he challenged Buffor: to look beyond his narrow world for evidence and comparisons (Buffon never travelied beyond France and Italy). In the course of his challerge he presented some of his ow evidence that Buffon knew nothing about and came up with a clear noition of mountain scructure. But he was more interested in discrediting those who were more given to natural philosophy than to natural science than he was in chaijenging one hypothesis with another. By point of conviction, he believed that rature existed in variety and it was actualiy harmful to science to contemplate the whole (as Buffon had cone in his "History and Theory of the Earth") on the basis of a few selective observations that did not go beyond the surroundings of one's own environment. ${ }^{20}$ Pallas set for himself the goal

19p.p. Belousov, "p.S. Pallas--Puteshestvennik i Geolog, "Friroda, no. 3 (1941), 111-116́, Khabakov, Ocheriki no Istorii. pp. $185-136$.

20 "observations," pp. 21-22. 
of bringing in the evidence.

Pallas' "Memoire sur l.2 Variation des Animaux" was presented with the same thrust as his carlier public presen. tation, in the presence of a swarm of dignitaries with the honored guest being the "Royal Prince of Prussia." After depicting for $h$ is listeners the two major trends, as he saw them, of contemporary natural history--excessive systematics (Linnaeus) and excessive non-systematics (Buffon)--he proceeded to cut his way between them, emphasizing the point that he consistently upheld in his lifetime that nature existed in variety, greater variety than could be systematized in a single scheme and greater variety than could be philosophized on with any degree of adequate proof, at l ast given the present state of knowledge of nature.

Having stated his position, Pallas moved to attack the zoological theory that had rapidly gained ground as a result of i.ts assertion by Buffon and Linnaeuss that the aninal world was in some cases inconstant, degenerative, and subject to variation to the tune of whole new species arising. Regarding animals, Pallas was in the arena of his major interest and he hacked away at his two famous contemporaries with clarity and precision, at the seme time raising points about his own general beliefs on the aninal kingdom. This was a significant piece of work. Darwin prized it, and ironically, because on the surface it appeared to be resisting the tide of biological thought. Those who cared to examine 
its contents saw the opposite.

It needs to be mentioned that Pallas did not disbelieve the propositinn that a'. existing specier were created and existed for the most part in the same variety and with the same distinctions as they had since creation. He never resorted to expianation by divine cause, but made no claim to know anything to the contrary regarding the origin of all or certain species. A Soriet authority on Pallas' biological views, B.E. Raikov, has made a point of emphasizing that Pallas' objection to the thought of transformation or inconstancy of species stemmed from $h$ is belief in the constancy of divine creation. 21 This is an ill-emphasized point to which another soviet authority, G.P. Dementev, has rightly taker, exception. ${ }^{22}$ The challerge to the notion that the species were created and constant was scientificaily in an infant stage, and rather than take excevtion to the possibility raised by some for the historical development of species, the entire thrust of Pallas" "Memoire" was in raising scientific doubts about the conditions advanced for such a possibility. In other words, his objection was to the validity on scientific grounds of the evidence used to demonstrate

\footnotetext{
21. Russkie Biologi-Evoliutsionisty do Darvina, pp. 85-102. Raikov's iarger point is that Pallas earlier in his career was on the road of evolutionary thought but after coming to Rusiia, because of the "reactionary conditions," he returned to orthodox science. There appears little substance in this view.
}

$$
22 \text { "Pallas," p. } 268 .
$$


the possibility of a species" transformation or degeneration. He had no ironclad attachment to the concept of constancy; he just saw the evidence against it as faulty. Tallas, as a matter of fact, never flinched in his support for the work of two importart eighteenth-century biological researchers, Joseph Koelreuter and Caspar Wolff, whose work had already shown hybriaization in plants (Koeireuter) and embryological development (Wolffi). Although Koelreuter's work was botanical, it wili be remembered that Pallas in one of his earlier works argued against a barrier between the plant and animal kingdoms, thus the process of hybridization and the prospects of changeability in plants could easily be carried over to animals.

Another point must also be mades it is inaccurate to think of Pallas or those he was chalienging as debaters of evclutionary theory. The debate was around a few evolutionary ingredients only, that it took biologists almost another century to develop and incorporate with other ingredients into a full-blown conception of progressive organic development. Some of the evidence gathered in the advances of eighteenth-century science tickied the minds of some and caused them to jump out ahead. Pallas yearned to drag them back and instruct them in the meaning of proper evidence and in ways to properly advance science. The opening paragraph of Pallas' presentation in 1780 summed up his attitude of the biggest scientific pitfall rather wells 
Quelque grande que soit l'obligation que les sciences doivent aux grands hommes, qui de temps en temps s'élevent par la force de leur génie et donnent une nouvelle impulsion aux connaissances humaines: on ne seuroit pourtant disconver: par les hypothéses auxquelies ils sont encilins à se livrer, par leur's opinions particulieres, souvent hazardées et le plis, pour ainsi dire, qu'ils donnent a leur science, ils ne deviennent souvent nuisibles et retardent peut-être tout autant l'avancement des lettres, bien donnant des entraves aur genies médiocres dortt les travaux reunis, n'etant pas assujettis par l'autorité de tels maitres, seroient d'une utilité trés-marquée, quoique moins brillante. 23

Pallas thought the speculations of Iinnaeus and Buffon were shackles on the development of his science--thoughts of brilliance, but thoughts that could backfire on the advancement of science. Furthermore, he disagreed with the content of those thoughts.

In his "Memoire" Pallas audressed himself specjfically to two basic doctrines that had been popularized partly by Iinnaeus but mainly by Buffon in his "Dégénération des Animaux." The first basic doctrine was that, through crossbreeding, animals hybrids were capable of arising. The second was that species could become transformed in ways apart from, but perhaps working alongsice, the processes of breeding; for example, by climatic influence, nourishment, or any environmental. change. Pallas discounted hyoridization in animals-.. in animajs in a natural state, that j.s. He established a long list of evidence to show that dogs and horses, for instance, were the product of crossbreeding, 24 but he did

\section{3"memoire," pr. 69-70.}

24 Darwin thought some of this evidence was a pioneering scientific achievement. 
so to estabiish the point that aninals under domestication were subject to artificial influences. "The tyranny," as he called it, "that man exercises on domestic animals"25 was hardly a fair measure by which to make assertions on the entire animal kingdom. Pallas roundly upbraided Buffon for drawing most of his evidence from domesticated animals and not making this distinction. In natural circumstances, Pallas argued, crossbreeding is not a phenomenon in the pattern of animal behavior. Instinct keeps the species apart and conserves their purity of origin because females prefer the best of the male specimens from their ow kind. Crossbreeding occurs in isolated circumstances, surely, but the hybrid offspring does not bring about a new species: it is either too imperfect to survive, sterile (which he thought was usually the case), or through reproduction with the originai species the offspring would return to the original form. The single weird specimen, in any case, would not perpetuate itself. The "air de famille," Pallas asserted, applied also to humans, but not necessarily to insects.

No other factor, Pallas thought, was as strong a potential argument for degeneration as the factor of crossbreeding. Thus the major part of his "Memoire" was in developing the arguments just described. The other factors (climate, etc,) he dismissed in short order. Animals adjusted, of course, to their environment, but environment could not

$$
25 \text { "Memoire," p. } 81 .
$$


alter the basic characteristics of a species. A change in behavior could result, maybe an alteration of color or the nature of fur as a resuis of envircminent I variation, but this was not the same as a new species arising. Again, however, a man-influenced environment was another matter. Constancy was the pattern for animals in a natural state; inconstancy could easily come about under the jnfluence of man's "tyranny." However, Pallas kney that patterns were not universally applicable. He knew of accidents and treaks, aside from domestication, which did not fit into his theme of constancy. This was the subject he proposed to take up on another occasion, but apparently the occasion never arose.

Pallas was not a man of theory and this article was not really very bold in that direction. He dia not intend for his important points to ring throughout the land; in fact they appeared in the midst of a maze of facts. It is not implausible that his audience was asleep by the time he asserted near the end of the presentation that animals and humans were commonly possessed of an instinctive "air de famille."26 At bottom and in retrospect, Pallas was standing in opposition to some of the first clear thoughts on transformation, and the development of those thoughts, we now know, followed a successful course. Pallas' theory was essentially an attack on theory, from which he raised imporiant biologicai points that had to be reckoned with in the further

$$
{ }^{26} \text { Ibjd. , pp. 99-100. }
$$


development of biological thinking; for instance, his regative thoughts on hybridization between different species, his thoughts on domesticativii and its effects vis-à-vis natural habitat, and his cail for need to renovate the study of animal. Iife by the systematic introduction of comparative anatomical and physiological criteria. Pallas was on firm scientific ground, which he felt certain wolld edge forward as the evidence came in, and equally certain to lose its way from excessive speculatian. In this he was no agent of pulpit or throne.

It may be too common, for historians at least, to measure biological developments in overeager expectation of midnineteenth-century developments, thus measuring the the ory to the exclusion of the subject behind it. Darwin was ar evolutionist because he was a biojogist. He possessed original genius as did Buffon a century earlier. In between marched the men, whether evolutionary-minded or not is to a large extent beside the point, who developed biological knowledge (in anatomy, physiology, and embryology, for instance) to a stage capable of Eiving rise to mid-nineteenth-century devej-opments. Pallas was one of them. It is an interesting fact also that Georges Cuvier, the recognized founder of systematic comparative anatomy (and, some say, of modern paleontology), was a vehement critic of Iean Iamarck (1744-1829), another who captured a glimpse of life's progressive development. Neither was Darwin's theory, to say the least, universally 
accepted among men who stood on firm scientific ground, who raised perfectiy legitimate scientific arguments, and who in no way can be accused of tryinz to block scientific pregress. It is not so strange that men disagree, but it is historicaliy inaccurate to discount the accomplishments of nen who in retrospect emerge on the wrong side of an eventually successful theoretica: argurnent.

The entire career of Pajlas in Russia demonstrates that he was a man of exceptional scinolarly energy. In general terms, his accomplishments were twofold, in penetrating for the scierific commities of Russia ard Europe alike some of the major aspects of Russia's natural conditions, and, in doing so, consistently calling for more thorough natural scientific methods. One of the major characteristics of his career fron 1774 to 1793 was in its diversity, but the major theme of his activities was his studies devoted to the zoological and botanical nature of Russia and Siberia. The diversities will be dealt with later.

Pallas initiated a number of projects in the decade of the 1770 's, following his return in $177^{4}$, most of it concerned in one way or another with making know his six-year scientific observations just completed. The pages of the Academy's Acta after 1774 are loaded with examples of the technical results of his zoologjcal and botanical concerns. He undertook to make additions to Johann Gmelin's Flora Sibirica, correcting its mistakes and enriching it with his own 
observations. 27 In 1778 appeared his first major zcojogical. study based on the material gathered during his travels. It gave Europe its risst view of Russian and siberian rodents. 28 "With a thorcugnness that was quite unprecedented," thought Erik Nordenskiöld, this work examined an entire order of animals including their anatomy, skeletal structure, and the conditions under which they lived, and was so detailed and comprehensive as to constitute "one oi the really sound pieces of work that paved the way for modern comparative anatomy. "29 A. Wolf thought it was also important of note in recording eighteenth-century developments in 200 logical anatomy. $30 \mathrm{By}$ 1780 he had also brought to a close his two-volume collection of zoological studies, Soicilegia Zoologica, begun earlier in Berlin but filled mostly with material from his travels. 31 In the decade of the $1780^{\prime} \mathrm{s}$ Pallas' productive capacity reached its peak, although his energies were spread over such a wide spectrum that a modern scholar would find it almost incomprehensibly haphazard. Perhaps it was; some of the work

27 Protokoly, III, 185.

28 Novae Species Quadrupedum e Glirium Ordine (Erlangen, 1778).

29 The riistory of Biolugy, trans, by Leonard Bucknali Eyre (New York, 1.949), p. 263.

30 A History of Science, Technoiogy, and Philosophy in the Eighteenth Century, p. 476 .

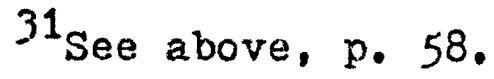


he considered central to his studies had to be put off or was left incomplete for reasons of other commitments and responsibilities, Still the pages of the Acta (after 1783 Nova Acta) were loaded with examples of the work for which he had originally been hired. In the early $1780^{\prime} \mathrm{s}$ Pallas offered Europe its first look at the insects in Russia and Siberia, one of the central studies on Pallas' agenda that nad to be put off. 32 Two issues appeared in 1781 and 1782 respectively; two others after he was settled in the Crimea.

A work even larger on Pallas' agenda was left unfinished, although unfinished in a pretty grand form. To do for the vegetable kingdom of Russia what he envisioned to do for the animal kingdom (wrap it up comprehensively in several il.ustrated volumes) had been a thought in the back of his mind for some time. His plant collections were vast; he had produced sone botanical articles; he had completed a minor monograph in 1781; but nothing yet to compare with his work in zoology. Perhaps recognizing that Russia's chief naturalist was neglecting the natural beauties of the realm. Catherine influenced palles to astion by commissioning him in 1782 to furnish a list of all the knowi vagetation in Russia, to give their names in Russian alongside their Latin names, and to use it as preparatory for a comprehensive descriptive work. 33

32 Icones Insectorum Praesertim Rossiae Sibiraeque Peculiarium.

${ }^{33}$ Sbornik IRIO, XIII, 357-366, "Annonce d'un ouvrage 
Pallas drew up the list and started to work on the larger work. In 1784 the first part of his Flora Rossica appeared: In 1788 the seco:d part appeared, nothing foilowed. 34 AIthough the published work was only about one-fifth complate as originally planned, what falias made available was so vividiy descriptive and richly illustrated that it was one of the celebrated botanical works of its day. The Emperor Paul I, who knew the work in its Russian translation furnished by $\mathrm{Zuev,} \mathrm{was} \mathrm{even} \mathrm{appreciative} \mathrm{enough} \mathrm{to} \mathrm{remark} \mathrm{in} 1797$. "I am fully certain that the author of Rossiiskoi Flory [Flora Rossica] has used his time in all things in researches and discoveries helpful to mankind." 35

botanique sur les hrbres, Arbustes, et Plantas de l'Empire de Russie, qui sera publié par Ordre et sous les auspices de Sa Majesté Imperiale," Acta Academiae Scientiarum Imperialis Petropolitanae, VI, pt. II (1.782), sect. I, 9-13.

${ }^{34}$ In print, that is. N,M. Zelenetsk:i has described at length an unpubiished manuscripi of Pallass that he found in the Academy archives and which he felt certain was a continuation of Flore Rossica. "Petr Simon Pallas, Ego Zhizr, Nauchraia Deiatelnost i Rol v Izuchenii Rastitelnosti Ross i.j." Zaoiski Novoros ijikayo Obshchestva Estestvoispytatelej, XLI (1916), 97-99, He was right apparently, for it was the same manuscript (Plantae selectae Rossiae) that Karl von Eaer uncovered in Leipzig in 1829, while doing investigative work there for the St. Petersburg Academy on another matter relating to Pallas, and brought to the attention of the Academy. According to Baer (Berichte, p. 35) Pallas did indeed intend it as a continuation of his flora, and although the manuscript was cumpleted, it was not published because there were no illustrations to accompany it, for which purpose it had been sent to Leipzig in the first place. Cf. Keppen, "Uchenye Trudy," pp, 414-41.5.

35 Quoted in Zelenetskii, "Petr Sinon Pailas," p. 72. 
Pallas was also occupied in the decade of the $1780^{\prime} \mathrm{s}$ with working out for publication material of deceased colleagues. The instances of Samuel Gmelin and Johann Güldenstädt have already been mentioned and these were the largest of his undertakings in editing. Güldenstädt's papers kept him especially busy. From beginning to end (over 1,000 pages) he put Güldenstädt's travel account into finished form, ${ }^{36}$ and by rummaging through the rest of Güldenstädt's papers, sorted out some of his representative work for inclusion in the Academy's journal. Pallas performed similar services for others, both deceased and living, and for the Academy. He thought the researches of Joseph Koelreuter, a former mernber of the Acadeny and now resident in Karisruh, in plant sexual.ity and hybridization were an important nodern scientific advance. He used Koelreuter's material in his "Memoire" to attack Iinnaevs' views on the same subject. He also on several occasions read recent articles on hybridization by Koelreuter vefore the Acadeiny and had them placed in the Academy's joumal.

Pallas was a standard Furopean authority in natural history, particularly zoology, and the foremost authority on the natural conditions of Russia long before his fortieth birthday. It was not surprising therefore that the knowledge and material he possessed was a sought-after commodity by European men of science ever anxious to know of new specimens. 
Pallas furnished a lot of material and illustrations from Russia that went into scme standard contemporary European works on zoclogy; for instance, those of Thomas Pennant and Johann Christian Schreber. 37 By others he was quoted and translated. He was a standard asquaintance to make for dignified foreign visitors to Russia, among whom he had the image of a widely traveled scholar of exceilence: he was "the learned Dr. Pallas." All English readers who did no more than keep up with the issues of the Annual. Register had read his words, for periodically there was extracted and translated anecdotal ethnographic items from his travel account. In his lifetime, English readers would also have become very famiiiar with who he was and a sampline of his work in the works of William Coxe, Edward Clarke, or William Tooke, and more briefly familiar through the works of others. He was not as popularly known, it seems, outside or England, but a much larger selection of his work was available in original or in translation.

Professionally, of course, Pallas was known and understood in quite specific terms throughout western, central, and northern Europe. Whatever diverse directions he noved in or was obligated to move in, which caused him to gain a more general reputation, he maintained throughout his career in st. petersburg a specific and laxge signiricance in his

\footnotetext{
37 Keppen, "Uchenye Trudj P.S. Pallasa," p. 411, Umess, ed., Istiers, p. 140n.
} 
field of basic devotion. But it is also true, and for good reason, that the more years he remained in $s t$. Petersburg, the more he became ko:m as a scholar on Russia of gereral proportions rather than as an academic natural scientist. In either case. St. Petersburg was not a den of obscurity. Pallas indeed wandered in diverse scholarly directions, which was not an unusial quality in the eighteenth century: but Pallas was more, much more, diverse than most (maybe all) famous naturalists of his day. The reasor stems from his expedition, to whichwere attached diverse obligations and from which he gained new insights, new interests, and material. to pursue them. The reasor stems also simpiy from his being In Russia and being a man given to studyinf; things. He was a scholar in a relatively (relative to western Europe) empty schoiarly pizyground. The academic atmosphere and the upsurge in academic activity, to which Pallas contributed, were also favorable factors in inducing a man of talent to stretch his capacities to the utnost. That he did so was evident from his having to postpone some of his work, from his level of production, and from his need in the early 1790's to pace In another direction for awhile. only the directions that he wandered in some depth will be given exampies here, since Fallas many-sidedness (as Russian writers have been almost uniform in introducing Paljas) resulted in some short, deadend roads.

Three that were not dead-erd but have already been 
outlined will not be reiterated--his fossil researches, his geological theories, and his ethnographic interests--except to mention a few points. In an age when investigation into all three areas was still very infant his work was innovative and farsighted-a purposefully guarded description because many have referred to his role in these areas much more liberally than may stand up under closer examination. Pallas, after all, was an eighteentr-century naturalist and as such had an almost open-ended commitment to examine all natural things, with the implication fully justified that most things were cone, by later standards, in a very shallow way. Still, however, he did systematically set about the search for fossils and was aware generally of what they reveaied; he did systematically observe mountain and other structures and was aware generally of gradual formation and many of the forces of nature; he did systematically set about the gathering of descriptive data about a people. His paleontological work resulted, aside from a rich supply of specimens for the St. Petersburg museum and an important contributing factor to forming his geologjcal views, in the Dutch scientist Peter Camper (1722-1789) opening a direct correspondence with Pallas on the subject. 38 His geological conceptions have earned hin most gererally, anong more exaggerated titles, the title of the de Saussure of Russia, in reference to Horace Bénédict

${ }^{38}$ Kanaev, "O Paleontologicheskikh Rabotakh F.S. Fallasa," p. 148. 
de Saussure (1740-1799) whose exploration and study of the Alps was a monument in early geclogical formulations. Pallas expressed his clearest notions two years before the first volume of de Saussure's monument. Yoyages dans les Alpes, appeared in 1779. The account of his later travels in southorn Russia made abundantly clear that he had not abandoned systematic geological observations. He updated, revised, and added to many of his earlier views on the basis of mountains he studied in the Caucasus and in the Crimea. Pallas' general ethnographic descriptions were substantial enough in adding to general material evailable on the peoples of the Russiar Empire, but were no more significant than what other travelers coliected. What has earned him a place of importance in this rogard was his work, both historical and ethnographic, on the Mongol peoples that has been already referred to. Fudolphi thought it made available more information on the Mongols than was availabie in any single source on any single people. 39 Cuvier eulogized it as classic and gave it a lengthy and ringing review. 40 certain pussians since have acclaimed him as a predecessor of Heinrich Klaproth (1783-1835) in Asian ethnography and inguistics. The work was a collection of historical documents and a conparative ethnographic description (somparative of different Mongol 40"Éloge Yistorique de Pierce-Simon Fallas," pp. 140-146. 
peoples) along historical lines. It was important primarily for its wealth of raw data and for his division of the Mongol tribes into three principal branches-mthe Morgols proper, the Kalmyks, and the Euriats. It was not, aspecially lengthy (both volumes together were just under 700 pages), but like other of his worixs was recognized in its time as a substantial work of precision. Parts of it were translated into French and Russian and it was presented in extract in its original German. Aside from the Mongols, Pallas also spent a considerable amount of time during his travels in 1793-1794 in ethrographic study, as his account of those travels makes clear. Perhaps his major effort on that cocasion was his effort to present a summary and comparative account of the peoples inhabiting the Caucasus, for which he used the works of prior travelers to that region as well as his own material. 41

Pallas' reputation in ethnography and linguistics was also in part established by a piece of work which received its inspiration in 1785 from Catherine. It was an obligation actually and an obligation that fallas was not anxious to undertake, to compile a comparative dictionary of all known European and Asiatic languages, with special emphasis on those spoken within the Russian Empire. He feit he was unqualified for such a task and that it was too far afield from his other work, but he was not in the mood to say no to the august

${ }^{41}$ Travels through ire southern Provinces. I, $381 \mathrm{ff}$. 
sovereign. He combined his own material with the extensive material given over to him by Catherine, coming up with a two-volume comparative dictionary of about 300 words in about 200 languages and dialects. ${ }^{42}$ It was obviously a work of grandiose conception that could have only a very sketchy finish, it was more important as a signpost to later Russian comparative inguists.

One of Pallas' major extracurricular interests, stemming naturally enough from his own expedition, was his interest in Russian geography and exploration. On the subject of eighteenth-century Russian exploration and discoveries on the Pacific, Pallas provided some of the solid information then available and which still provides solid source material. The basic depository for the work he completed in this area of interest was the periodical publication that he began to edit in 1781. Neue Nordische Beyträge, most of the material for which Pallas personally provided either by articles he wrote or by translations he made of accounts of Russian voyagers between eastern Siberia and Alaska. 43 Most of the

42 Linguarum Totius Orbis Vocabularia Comparativa (st. Petersburg, 1786-1789). Also published under its equivalent Russian titie. Catherine, according to Keppen ("Uchenye Trudy P.S. Dallasa," p. i31), had long maintained a specific interest in comparative linguistics and it was the extensive naterial which she had in the past ordered collected which served as the basis for this undertaking by Pallas, vhom Catherine deemed the most competent, to hanale it.

43 Neue Noraische Beyträge ultinately consisted of seven volumes, four of which were published from 1781 to 1783, the last three from 2793 to 1796 . It was actualiy 
material presented in the seven volumes of this publication (1781-1796) was intended in one way or another to provide information on the obscure northem pacific part of the world. The reason for his interest and the nature of most of the material he presented (translations or translated abstracts of firsthand accounts) were summed up by Fallas in a preface to one of his translations:

With respect to a region of our g]obe [northern Pacific] of which gcod accounts have been hitherto so rare and those on hand so contradictory [with respect to geogxaphical information]. . We must seek by comparison of such different current reports to clear gradually the true from the false
and to correct the mistakes . 44 f

of the nature of an occasionally appearing volume of collected material and essays, but is usually classilied as a periodical. Nine of the items provided by Pallas from vciumes I-IV have been translated into English by James R. Masterson and Helen Brower in "Bering's Successors, 1745-1780: Contributions of Peter Simon Pallas to the History of Russian Exploratiors Toward Alaska," Pacific Norihwest Quarterly, XXXVIII, no, 1 (Jan., 1947), 35-83; and XXXVIIT, no. 2 (Apr., 1947), 109-155. This has also been issued in book form (Seattle, 1948). All but two of the rine translated items are brief accounts of various Russian voyagers on the Facific between northeastern Siberia and Alaska which Pallas had translated from Russian into German; one is a lengthy article which Pallas wrote ("Commentary on the Discoveries That Have Been Made in the Eastern Ocean between Siberia and America"); and one is geographical "Memoranda" pertaining to a map of the northerm Pacific which Pallas wrote. Masterson and Brower comment (XXXVIII, no. 1, 47) that had these rine items appeared in a single volume, it might have been as standard a contemporary authouty on Russian exploration in this region as was Wiliiam Coxe's Account of the Russian Discoveries between Asia and America pubijshed in 1780 (much material for which, incidentally, coxe gained from Pailas).

$$
144 \text { In Masterscn and Brower, "Bering's Successors," }
$$
Pacific Northwest Quarterly, XXXVII, no. 2 (Apr., 1947), 144. 
The general attitude of endeavor expressed here was quite typical of what motivated Pallas' entire scholarly career. Pallas interest in the extreme eastern part of the Russian world was not entirely geographical; he was as much interested in the flora and fauna of the region, which led him to investigate minutely all the literature of prior travelers and explorers to the area, since he was not himself, of course, personally acquainted with northeastern Siberia and the Pacific. He left no stone unturned. He was fully up to date on all the details of Captain Cook's recent voyages and discoveries. He was just as fully up to date on a large Spanish expedition from California to Alaska undertaken in 1774 ; in fact he translated at length the account of that expedition for his Neue Nordische Beyträge. 45 And he was of course aware of everything done under Russian auspices, past and present.

On several occasions between 1774 and 1793 Pallas displayed his expert familiarity with the geography of the eastern parts of the Russian Empire and of the need for more expediticnary activity to sclentificaliy exarine little-known parts of Asiatic Russia by presenting proposals for expeditions to be sent to precise locations. In 1776 he raad to the Academy and presented to the Director (Sergei Domashnev) a detailed outline of recommended areas in Siberia for further

$$
45 \text { III (1782), 198-273. }
$$


exploration. 46 In 1779 he presented another proposal for a scientific expedition to the extreme east of Siberia. 47 mese proposals id not naterialize; perhaps because they were larger enterprises than the govemment would consider so soon after the completion of the large-scale and expensive expeditions of 1768-1774. The Academy's Director, Domashnev, however, had warmly encouraged them.

Things did materialize in the $1780^{\prime} \mathrm{s}$ with the Billings Expedition of 1785-i794 to the northern Pacific area, not an Academy undertaking but nevertheless an undertaking which Fallas-"then in Ereat favour"-heiped to get off the ground by his owm support and by his influence with catherine. 48 For this occasion Fallas prepared the instructions for the naturalist on the expedition, some items from which are worth reproducing as revealing of Pallas' attitude as to what a naturaiist, in several instances, ought to systematically set about to investigatey in other words: what he himself would have done and what he in fact had already done in his

${ }^{46}$ Güldenstädt and Lepekhir. also presented ideas on further expeditions. Protokoly. III, 252. The full text, of Pallas' proposal is presentei in Gnucheva, ed., Materialy dila Istorii, pp. 133-134; a sumary in Khabakov, ocherki po istoris. p. 190.

47 Protokoly, III, 4443 Gnucheva, ed., Materialy dIia Istorii, pp. 138-139 (for the text in full); Khabakov, Dcherki po Istorii, p. 191.

48 The quotation is that of Martin Sauer, the secretary on the Billings Expediticn. Sauer knew Pallas personally and fully affirmed his influence with Catherine on this occasion. An Account of a Geographical and Astronomical Expedition to the Northem Parts of Russia. . in the Years 1735 to 1794 . . . (10nion, 1802), p. viii. 
own work. His standards were high. Referring to geological matters (Article III), Pallas ordered Mr. Patrin, the naturalist: 49

You will describe in a very particular manner the extent, connexion, and direction, of the chain of mountains; their shapes, superfices, declivities, and heights; the rocks or soils of which they are composed; the strata that they contain, and their direction; craters, remains of extinguished volcanoes, and such as are actually buming. You are to collect specimens of all sorts of rocks, earths, petrifactions, lava, fossil, renains of animals, minerals, salts, and sulphurs; carefully numbering them, and noting the spot where found; also collect all remarkable stones and pebbles brought down by rivers, or thrown up by the sea, as well as such as may be in use by the inhabitants.

Relating to what ought to be observed in ethnographic matters

\section{(Article IV), Pallas instructed:}

With regard to the people that you may visit, you will observe their dispositions and different corporeal qualifications; the ir government, manners, industry, ceremonies, and superstitions religious or profane; their traditions, education, and manner of treating their women; useful plants, medicines, and dyes; food, and manner of preparing it; habitations, utensils, carriages, and ressels; manner of life and economy; their modes of hunting, fishing, making war, and treatrent of domestic animais; likewise ianguages, of which you will collect vocabularies, according to the plan sent with the Expedition, marking the pronunciation according to the Latin orthography. You will also try to procure the dresses, ornaments, instruments, and arms of these people,

${ }^{49}$ The following are quoted, without changes in speiling, from an English translation of Pallas' irstructions presented in Sauer, An Account, Appendix No, VI, pp. 50-54 (the Appendix is paged separately from the text). I have seen it mentioned (Academy of Seiences of the U.S.S.R., The Facific, p. 166) that Pallas also wrote a special linguistic instruction for the expedition, which he refers to in suticle IV of this instruction, buc I have not actually seen it and it is not Eiven by Sauer. 
or cause them to be drawn. You will likawise make descriptions of tombs and other monuments of antiquity.

Many other things were expected of Mr. Patrin, czpscially in observing flora and fauna. What Pallas' zoological works were noted for advancing in method of observation in his day was summed up by him in his instruction (Article VI) to Patrin that in observing all animal species to observe "as closely as possible their habits, food, propagation, sounds, migrations, and habitations..."

Four years before the commencement of the Billings Expedition, in 1781, Palias had hopes of personally doing some more exploring. During the summer of that year Count Alexander Stroganov se out on a tour of Siberia and Fallas obtained permission to accompany hini. Pallas went as far as Moscow, where he fell ill and had to abandon his plans, 50 Until 1793 he confined himself to the academic side of exploration, which was much more extensive than the examples noted thus far.

In 1781, at the same time Pallas was preparing to depart with Strogar:ov, two of his younger Russian colleagues in the Academy, Vasilii Zuev and Fedor Moiseenkov (1754-1781), were preparing for separate journeys to southern Russia (Black Sea area). Pallas wrote their instructions pertaining to

50 Acta Academiae Scientiarum Impenial is Petropolitanae, V. pt. I (1781), sect. I, 6-7: Protokoly, III, 532, 546; Umess, ed., Letters, pp. 151, 154. 
natural history. 51 Several years prior to that (1777) Pallas wrote an essay: in Prench at the request of Buffon in Paris, on the discoveries in the Pacific between Siberi- and Americam his first piece of work relative to the northern Pacific. 52 In 1778 the English traveler, historian, and clergyman, William Coxe, arrived in st. Petersburg for what resulted in a very enriching stay. He and Pallas became warm acquaintances and apparentiy spent some time in comradely discussions of old times. At any rate, Coxe gained enough information on Pallas to write a summary but accurate account of pallas' life and work up to that time to include in the account that he wrote of his travels. 53 coxe was interested in engaging

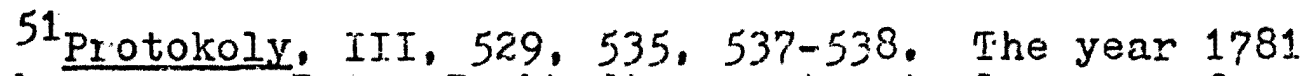
was a busy ones Peter Inokhodtsev set out also on a fouryear expedition of European Russia mainly for cartogxaphic reasons. Moiseenkov, who had just entered the Academy in 1779 along with Zuev and ozeretskovskii, died in Moscow just after setting out from St. Petersburg. Zuev completed his travels in 1782 which had taken him as far as Constantinople.

52 Buffor received it in manuscript. Pallas later wrote the essay in German and put it ir the first volume of $h$ is Neue Nordische Beyträge, and it is the sane articie that has appeared in Engitish translation in Masterson and Brower (see above, p. 151).

53 Coxe's multivolume Travels into poiand, Russia, Sweden, and Denmark. . wert through severai editions. Regarding the only two ecitione I have seth the account he wrote of Pallas which appeared in vol. III of the 3rd edition (London, 1787, pp. 243-260) contained the account of Pallas' life ard a detailed ist of the work Pallas was then doing; the account which appearea in vol. IIJ. of the 5 th edition (London, 1802, pp. 203-221), which has been reprinted, deleted the deiailed list, leaving just the summary account, which is both very adequate and accurate (but less detailed) wher compared to ihe later accounts of Pailas, particularly when compared to the accoun's of kudolphi who had zccess to Pallas' private papers. 
was necessary to obtain official permission, which he received along with transportation needs after he was introduced to Pallas and after Pallas intervened with the necessary officials to procure them for his new American friend. 56 Ledyard traveled deep into Siberia, but did not complete his planned itinerary due to his arrest at Iakutsk by Russian ofricials. 57 As far as he went, he had kept Pallas informed of all phases of his journey.

In addition to Pallas' scholarly productions relating to Russian exploration and his association with various expeditions from 1774 to 1793. Pallas had other ties to this area of interest two of which stand out. In 1776 the Academy's advencement in Eeographical knowledge received a large boost by the unveiling of a new, just compieted, general map of the Russian Empire. 58 simultaneously thare wàs formed in the

56 Stephen D. Watrous, John Ledyard's Joumey Throukh Russia and Siberia, 1287-1288: The Journal and Selected Letters (Madisor, 1966), pp. 41, 123-124, 139. Other material on Ledyard and $h$ is traveIs can be gained by following the account and notes in Bolkhovitinov, Stenovlenie, pp. 282-295.

57 At Iakutsk in January 1788 Iedyard had run into the Billings Expedition. Sauer (An Account, pp. 99-101) wrote of the encounter and explained the circumstances of Ledyard's arrest there.

${ }^{58}$ It was unveiled carenuritously at the Acadeny's jubilee session ceiebrating its half-century anniversary, in the same ceremonjes that witnessed all. Academy members appear at the Falace to present Catherine with all 20 volumes of Novi Commentarii (see Bibitography, item 1). M.I. Sukhomlinov, "Piatidesiatiletnil i Stoletnii Iubilei S.-Peterburgskoj. Akademji Nauk," Russkaia Starina, XVIII $(1.877), 12$. 
Academy a committee of four (Pallas, Lepekhin, Güldenstädt, and Rumovskii) to work out in detail a plan on how to proceed with producing a cornple ve physical and to yographical description of the Russian Empire. The plan for the grand project was completed and presented in 1778 in a detailed, five-part prospectus. 59 As Pallas was aware, however, there was much more expeditionary work to be done before any sort of a general and authoritative geographical work could actually be undertaken; hence, his two specific proposals (1776 and 1779) for expeditions to various regions needing further investigation and his work ir trying to sort out the geographical facts of eastern Siberia and the northern Pacific. Regarding the latter, Pallas in great depth celved into a study of the available information and accounts pertaining to the northern Pacific hoping that a critical examination would separate "the true from the false." Geographically speaking, he indeed succeeded to some extent. As early as 1781 Pallas was able, on the basis of what material he had already collected and on the basis of the most recent data fumished by Captain Cook's latest voyage, 60 to make many

59"Prospectus a'une Description généraie topographique Et physique de l'Empire de Russie, projetté par 1 Académie imperiale des Seiences de st. Pétersuourg," Acta Ácademiae Scientiarum Imperialis petropolitanas, II, pt. I (1778). sect. I, 3-37. Keppen ("Uchenye Trudy P.S. Fallasa," p. 419) ascribes this work to Pallas.

60 The third voyage begun in 1776, the maps and data. of which Pallas in 1779 requested Pennant to send him from Fngiand. Pennant complied. Urness, ed.. Letters, p. 56. 
cartograptic correstiors of the northern Pacific region. 61

The other fact of Pallas' career which further tied rim to an interest in those matters was $h^{*} . s$ appointment in 1786 to be historiographer of the Adniralty, which, among other things, involved rim in working with jourmals and maps of past and current Russian navigators. Tre last three voluines of Neue Nordische Seyträge (1793-1796) resulted to a great extent from naterial pallas had come in contact with at the hdmiralty. Pallas' position on the Topographical Committee as weli as his position in the Admiralty were thus related very closely to the work he produced relative to Russian discoveries and geography.

That Pallas enjoyed great favor from high places ha: already been mentioned on several occasions; his position in the Admiralty furnishes yet arother example. He was also a nember of the St. Petersburg Free Economic Society ffounded in 1765) for which he wrote a number of articles on agriculture, forestry, and other matters relating to rural economy and wich appeared in the periodically appearing Works (Trudy) of that Society. In adition, Pallas was entrusted by Catherine in 1791 to deliver instruction to her grandchjldren (Constantine and the future Alexander I) in the natural sciences, and was showered with several honorary titles and duties. None of this was very central to pallas'

${ }^{61}$ See especially the remarks Pallas wrote in 1781 "Menoranda Relating to the Appended Map" in Masterson and Brower, "Bering's Successors," pacific Nortbwest Quarterly, XXXYIII, no. 1 (Jan., 1947 ), $80-83$. 
career. The obligations that attenaed the honors actually began to weigh heavily and contributed to his decision to abandon St. Potersburg.

A matter of more interest, though perhaps of no more significance, to Fallas' career in St. Petersourg was his rather bad relationship with Princess Dashkova (1743-18i0), the Academy's Director from 1783 to 1794. Dashkova was competent and without question performed more services for Russian intellectual life as ar Academic administrator than any cther in the eighteenth century. But at bottom there were deep-seated differences between Dasinkova and PaIlas. Her jntellectual interests were mostly literary; Pallas' were scientific. She was a storehouse of activity, quick to change, eager to move. Palias was a stcrehouse of krowledge, prudert to change, not eager for rapid novement. Pallas was in no hurry; when he took a step in the intellectual world, he stepped (usually) on very sure ground. He vas a fact-gatherer and fact-absorber, and only on the siow processes which that implied did he choose to let nis inteliectual principles stand.

Two issues poisoned the atmosphere between Dasnkova and Pallas. Both were raised in the year following Dashkova's appointment as Director--in 1784--and one of them continued for several years,

In February 1784 Dashkova declared that Vasilii zuev was to be excluded from the Academy as an wrworthy adjunct 
who was not fulfiling his duties. 62 pallas was outraged and brought the matter of whether or not Zuev was a competent scholar to a vote at tho next Academic session, four days later. The majority of menbers upheld Dashkova's position that 2 uev was not fulfilling his duties. 53 pallas did not let the matter droo. He protested further, declaring that Dashkova had no authority anyway to single-handedly exclude a member of the Academy. He appealed to the other academicians, to the Empress, and further insisted that his protest be inserted in the proceedings of the Academy. 64 Dashkova countered by appealing to the Academy members for a general vote of confidence. She again was uphelds only two, Pallas and Anders Lexell, voted against her. 65 Suddeniy, three days following this vote (in March), Lashkova declared that zuev was roinstated. 66 What swayed her is not mentioned in the

62 Zuev had become Pallas' adjunct in natural history in 1779, after he had returned from the University of Strasbourg:

63 protokoly, III, 724--725.

${ }^{64}$ This in March. Ibid.. pp. 728-729.

65 Ibid., pp. 729-730. Pailas at this point interjected a statement of principle: "Pour moi j'ai toujours sú respecter dans la persorne de Madame la Princesse et de ses Prédécesseurs, les Chefs préposés a I'Académie par notre grande Souveraine; mais je n'ai pas renoncé au droit, que ma place d'Académicier. me donne, de dire mon sentiment ljurement dans les délibérations académiques." As quoted in F. Keppen, "PetrSimon Pallas," Russkii Biograficheskii Slovar, XIII (1902), 159. This statement does not appear in the Academy proceedings and Keppen does not quote the scurce.

$66_{\text {Protokoly. III. } 731 .}$ 
Proceedings; whether Palias' strong protest, Zuev's own appeal, or the possible intervention of the Empress, to whom Fallas had tried to appeai over Dashkova's head. The "right and wrong" of the maiter is obscure, but it seems unlikely that Pailas would have upheld a scholarly incompetent indivicual. On the other hand, there nay well have been irregular factors in Zuev's life to offset his quite obvious brilliant capacities to which Dashkova, but not Pallas, took exception. A similar case several years earlier involving another of Pallas' expeditionary students, Nikita Sokolov, seems rot to have raised Pallas' ire. Following the expedition, Sokolov had gone to Europe with Zuev and Ozeretskovskii and returned with them in 1779, all having completed their studies at Strasbourg. On the same day ir. 1779 zuev and ozcretskovskij. were elected as adjuncts in the Academy; Sokolor was not, , due to what Domashnev, the Director at that time, declared to be his "irregular Iife."67 It was Dashkova in this instance, soon after her appointment as Disestor, who paved the way for Sokolov's entry into the Academy. 68 Both Sokolov and Zuev wers elected as ordinary academjcians on the same day in 1787 and were not again interfered with. (Ozeretskovsiki preceded both by five years).

The other issue was raised around Pallas' working on Güldenstädt's travel notes for publication. Güldenstädt, it

67 Ivid., pp. 533-534.

${ }^{68}$ In Maxch 1783. Ibid.. p. 657. 
will be recalled, died in $1 ? 81$ without having put into print the general account of his travels. Two months after Güldenstüdt's death, Pallå undertook to simuitátieously edit all of his travel. notes as well as the final part of Gmelin's travel account. 69 Pallas went to work first to complete Gmelin's travel account by adding the fourth and final volume. ${ }^{70}$ With this completed in 1784, he set to work or Güldenstädt's material, a task that would be more timeconsuning because the work had to begin from scratch and because, as Pallas explained, Güldenstädt had left his papers ir less than an orderly condition. 71 in November 1784 Dashkova raised the point that Pallas was dragging his feet on the matter and thought someone else ought to be given the Güldenstädt papers for editing. ${ }^{2}$ Pallas barked back by explaining the work and difficulties involved, adding that he thought Dashkova's charge of delay to be "reprehensible." At nearly evory session of the Academy from mid-Noventer to mid-December 1784 either Dashkova or Pallas, or both, had something to retort to the other on the matter. Finally, in mid-December, Pallas won the day by declaring he would not relinquish the Güldenstädt papers to someone else and he

\footnotetext{
${ }^{69}$ Ibid., pp. 532-53j.

${ }^{70}$ See above, p. 77 .

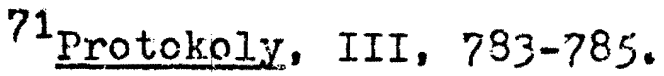

72 Ibid., p. 781 .
} 
expected that sometime in the following year would appear the first volume. 73 Because of his reputation and influence Pallas wos able to uphold his position and for a time, at loast publicly, the argument was dropped. Indeed in May of the following year (1.785) Pallas presented the first volume in manuscript of Güldonstädt's travels and submitied it to be printed. 74 It appeared from the printers only in 1787 , by which time Dashkova again became a thorn in Pallas' side by calling for the appearance of the rest of Güldenstädt's travel account. Apparently Pallas by this time had turned a deaf ear to the Director, who continued at intervals to publicly (in the Academic sessions) express dissatisfaction with Pallas' progress right up to the tirne when Pallas presented the manuscript for the second, and concluding, volume early in 1790.75 If Pallas responded to Dashrova's continual prodding they were not recorded in the Procesdines of the Academic sessions. The second volume of Güldenstädt's travel account appeared in print in 1791.

Palias' progress on the Güidenstädt papers was slow, to be sure, but was not uncharacteristic of the way he proceeded to go about things. At most times he had a handful of projects going at once and much of his major work, except

$$
\begin{aligned}
& 73_{\text {Ibid. }} \text { pp. } 787-788 . \\
& 74 \text { Ibid. pp. } 314-815 . \\
& 75_{\text {Ibid., IV, 62-213 jassim. }}
\end{aligned}
$$


for articles and a few monographic works, had to await completion for a number of years after it had originally been initiated. This can be seen in some of Fallas' works wich have been noted thus far, which, it should be added, represent only the most noticeable of Pallas' written work from the major fields in which he worked. Because of his heavy and diverse schedule, in addition, by the early 1790's he had not yet really commenced work on the projected piece of work highest on his agenda--the overall zoology of the Russian Empire. But for the moment he needed a rest, to get away, to travel for awhile under warmer and less hectic skies. Late in 1792 he asked Catherine to be granted a one-year Ieave. It was granted, Pallas was to have the period from January 1793 to January 1794 free from all duties. 76 Nearing the end of his allotted year, Pallas, by that time in the Crimea. and in no hurry to return to St. Petersburg, appealed for and was granted a year's extension.

76 Nova Acta Academiae Scientiarum Imperialis Petropolitanae, $X(1792), 4-5$; Protokoly, IV, 316 . 


\section{CHAFTER VI}

\section{LATER YEARS: SECOND EXPEDITIOH \\ AND RESIDENCE IN THE CRIMEA}

It is tempting to describe the second expedition of Fallas as Pallas vacation venture. In context it was that; however, in substance it was a scientific expedition. Pallas intended to mix relaxation with personal work. He was on his own, although he kept the Acadeny informed of his progress, and he kept a detailed record of his travels and observations. There were no students along. The main body of the expedition consistei of Pallas, his family, ${ }^{1}$ and his favorite illustrator from Leipzig, Christian Geissler.

Pallas departed from St. Petersburg on the first day of February 1793 with eleven months remaining to travel at is leisure. For several months he traveled a familiar route-familiar, that is, if his memory was vivid. Through Moscow, then eastward and southward, Pailas reached the middle Volga and followed its course south, through Saratov and Tsaritsyn, to Astrakhan. This was accomplished within a three-month period; five weeks of that were spent in Tsaritsyn. Pallas

${ }^{1}$ fallas family consisted of his second wife and his only child, a daughter, borr by his first wife in 1778. Pallas first married in 1767 in St. Petersburg. His first wife died in 1782, Ho married again in 1?86, but had no children by her. His second wife died shortly before he returned to Berlin in 1810. I have nowhere seen it mentioned the nationality or the name of either wife. 
departed Astrakhan at the beginning of May and from there the territory was new to him. He was reading further south, into the Caucasus Mourtains, where he spent the better part of the summer months. Then, at the end of August, he set out to attain his final destiration--the Crimea. ${ }^{2}$

Because his leave was extended, Pallas was able to spend a good deal of time in the Crimea. September and october were spent making exoursions in 211 directions before he settled in Simferopol, in the southern part, for the winter. He was waiting for spring to come to produce its flora, and arter he gathered a thorcugh sampling of what the crimea had to offer, he went back to st. Petersburg, arriving in midSeptember 1794.

Fallas' second expedition was not a large event in the history or Russian exploration, but from it followed two developments of majcr interest to Pallas' career. The first deveiopment was a result of Pallas' readiness for retirement and the impressions that the Crimean surroundings and climate had left on him. When he ariived back in St. Petersburg he wasted no time in petitioning for retirement and a place in the Crimea on which to retire. His wish was generously fulfilled, ${ }^{3}$ and in less than a year after he returned from his expedition, he was on his way south again (mid-August 1795)

2 At the time known as Taurida, this "lorg-coveted region" was annexed to the Russian Empire only in 1783.

${ }^{3}$ See above, p. 122 . 
to establish a new residence in simferopol.

The second development was the appearance of $\mathrm{his}$ travel account, which my consider to be a classic piece of descriptive iiterature and far superior in that respect to the account of his first, and far more important, expedition. Pallas did not write the final product right away, but he did put into print immediately a brief, general description of the Crimea which was immensely popular and appeared in a number of French, German, and Russian editions. The original was written in French and read before the Academy soon after his return. ${ }^{4}$ The larger work appeared after Pallas was well establjshed in the Crimea. Originally appearing in German in two volumes (1799-1801), Paijas' Bemerkurgen auf einer Reise in die südlichen Statthalterschaften des Russischen Rejchs in den Jahren 1793 und 1794 had as great a success as his earlier, more important travel description. Although it never appeared In Russian in full translation, immediate and full transla.tions made Palias' work available in French (1799-1801) and English (1802-1803), with both, like the original, going through several later editions. The entire second volume was devoted to the Crimea in ail its physical, natural, and

4"Tableau physiqlis at topographique de la Tauride," Nova Acta Academiae Scientiarum Imperialis Petropolitanae, $X(1792), 257-302$. Although placed in the 1792 issue of Nova Acta, the essay was read on January 29, 1795. Amorig the German editions to appear. Pallas made his own and put it in the 7 th volume (1796) of Neve Nordische Beyträge. Aside from in periodical publications, the "Tableau" appeared as a separate publication in all three languages. 
ethnographic f'eatures; it was quite apparent that Pallas had gone over the land thoroughly and with an excited imagination. It was also apparent that the Lilustrator Geissler kept his drawing arm very busy. Both velumes together were embellished with over fifty color plates, very beautiful and very descriptive. 5

Rich in vegetation, beauty, and warmth, the rural surroundings of Simferopol acted on Pallas, as one has put it, as an "irresistible lure." 6 A place to rest and work in solitude, with a garden or two to provide a means of hobby and botanical observation, was foremost in Pallas' mind, and he thought he had found a virtual valley utopia in the southern Crimea. He had a lot of scholarly tasks planned for his remaining days; foremost was to get to work on his zoological masterpiese. But a number of other things awaited completion, some of which had lain dormant for some time. Demanding immediate attention was the full account of his recently completed travels. As a matter of fact, there was little to indicate that pallas intended a slow-down in his scholarly work. In a letter to Georgi, dated late in 1797, Pallas communicated that he was simultaneously working on his grand zoology of Russia, on the completion of his work on the

5 Which were preserved, by the way, in both the French and English transiations.

6.A. Sontsov, "Pallas v Krymu," Drevniaia i Novaia Rossiia, I, no. $3(1876), 280$. 
Mongols, and on a botanical study. ${ }^{7}$ During the first few years of his residence in the Crimea, Pallas initiated and completed, in fact, sevaral botanical mongraphs and presumably ${ }^{8}$ was proceeding with a continuation of his Flora Rossica. Taking advantage of his rural solitude, Palias was hurrying to complete and add to his life's work.

Pallas' place of rest and solitude became gradually a place of too much solitude and too little rest. At best his valley utopia was a mixed blessing, and he found as the years crept on that he had replaced a hectic city life with a hectic rural life. For a man of scholarly pursuits, in addition, his isolation from the scholarly centers began to weigh on him. Pallas had not actually severed his ties with the St. Petersburg Academy. He was still counted among the academicians, still providing articles for the Academy's journal and sending (most of) his other works there to be reviewed and published, and was expected to conform to all Academic regulations, which had considerably tightened since his departure. It was soon after he had sent one $O \vec{I}$ his recently completed botanical works to Leipzig to be published that the Academy administrators, early in 1800, sent hin a copy of all the most recent regulations pertaining to censorship, including the regulation which prohibited a work written in Russia from being sent abroad for publication.9 Pallas' ties

7 Protokoly, IV, 620.

${ }^{8}$ See above, p. $143, \mathrm{n} .34$.

9protokoly, IV, 793, 801. Most obnoxious restrictions 
to the Academy, however, gradually faded as his former colleagues were one by one being laid to rest and for all intents and purposes, tholigh not officially, afte: the beginning of the nineteenth century he had no connection at all except for an occasional communication. It seems, in fact, that he became practically a forgotten man in St. Petersburg. There was no eulogy delivered there either when he departed Russia in 1810 or when he died in 1811.

Pallas referred to his growing disappointment in Crimean life in very clear terms in the preface to the second volume of his Travels (1801): "Were this the proper place to inform my readers of the disquietude and hardships which oppress me in my present residence, and embitter my declining day, I covid easily apologise for the late appearance of this volume." Pallas was referring to the problems or rural management in the Crimea which he encountered and which interfered to a distressing degree wj.th the atmosphere of caim he had counted on to close out his scholarly career.

Pallas was originaliy given a house in Simferopol and two estates consisting of scattered plots of land in the midst of Tatar possessions. He was also provided with twenty peasant serfs to perform the labor. Pallas succeeded in buying up surrounding land to join and add to his original possessions, but from the first he found himself in the middle of land

relating to printed matter were rescinded the following year by Alexander $I$. 
disputes with Tatar neighbors and a particularly troublesome Russian neighbor, a Major Chemyshev, who, according to Sontsov, was constantly bringing legal action and encroaching on what Pallas considered to be his land. ${ }^{10}$ Between Tatar neighbors and Chernyshev, Pallas was involved in persistent legal suits which ended only in 1807 with Pallas being forced to give up claim to over half of his possessions; from about 3,200 desiatin (c. 8,640 acres) he was jeft with about 1,350 desiatin (c. 3,645 acres). This should be set against the fact that from the time of Paul I's accession to the throne most of the local administrators in the Crimea, who had been instructed to assist Pallas in every way and with whom Pallas had established friendiy relations, were replaced by men who did not know and were less sympathetic to patronizing Pailas. It should also be set against the fact of a man trying to accomplish major scholarly goals free from muntane concerns. In many ways, however, Pallas found in the southern Crimea the features of life he had been seeking, at least for the first seven or eight years of his residence. In working in his gardens and cultivating grape vines--two of his most enjoyable pastines--he could spend as much time as he wanted. He frequentiy took leisurely excursions in the

\section{0"Pallas v Krymu," pp. 286-288. Sontsov's article} is a substantial account of Pallas' Iife in the Crimea and is based on official records and firsthand information that he was able to uncover in Simferopol. AIthough listed as orily 10 pages in length, long double columns on each page make it a corsiderably more lengthy account than 10 normal pages. All of my information and figures pertaining to land matiers are taken from it. 
Crimea which were a further source of pleasure, as well as a source of botanical collections. Before he departed from the Crimea in $18: 0$ he ridu comprehensively catalogued and described its vegetation. In studying, experimenting, and writing on matters of rural economy, he had aiso made many practical contributions to Crimean agriculture. ${ }^{11}$

Pallas received many visitors at $h$ is home in Simferopol which helped enliven his rather isolated academic existence. Two of his more noted guests, Edward Clarke and Vladimir Izmailov, have left some very clear impressions of the time they spent vith Pallas. Clarke, who visited Pallas in 1801, described a "mild and amiable Pallas," ${ }^{12}$ who was a most gracious host, who enjoyed the opportunity to accompany Clarke on several excursions around the Crimea, and who was quite content with his rural life. Izmailov, who visited Pallas two years earlier, in 1799, described a "fresh and cheerful" Pallas, sharp in speech, keen in judgement, with a particular fondness for reminiscing about his former travels. Izmailov also caught a side of Pallas which his record of is worth noting:

Pallas displays unusual modesty anà cares litt].e about his fame; splendor does not affect him. His moral character is shown in his uhilosophical opinions. He attributes the rise of moral decay to an excessive accumulation of people in large cities, where vices feed on each other and corrupt morals similar to the way that bad vapors contaminate

\footnotetext{
11 Zelenetskij, "Petr Simon Dallas," pp. 64-69. ${ }^{12}$ clarke, Travels, p. 360 .
} 
the air. He dces not believe that a universal improvement of the mind, a kingdom of virtue, or a general enlightenment can ever exist on earth. Science, in his opinion, must be the possession of certain selected minds; all others should be satisfied with only the simplest truths. To my retort that man was born with the gift to feel, to think, and to gain enlightenment, he replied that the Tatars have not in the least enlightened themselves from the time of Herodotus to our own, and in essence are the same crude Scythians described by that famous historian. If in the course of two thousand years the intellectual condition of an entire people has in no way changed, Pallas then proposes that reason must be confined within certain bounds. Once when discussing with me the moral decay of our time, he stated that truth o'xght to remain the preserve of we academicians. I must adinit that so arrogant a thought coming from the least arrogant of men can hardiy, in ny eyes, be justified, even with that sense of indignation which the bloody era of our time has aroused in him. 13

Pallas' use of the Tatars 3.S an example may have been colored by his land disputes. At any rate, neither Izmailov in 1799 nor Clarke in 1801 described the same man that Pailas had referred to in the preface to the second volume of his Trave?s. Ferhaps his private dealings were never brought up.

Shortly thereafter Pallas' health began to deteriorate to the point where all the activities related to the supervision of his lands, his personal cultivations, and the disputes he was engaged in became ever more burdensome and disquieting to his scholarly tasks. It was all he could do

13 Irmailov's conments are from his book puteshestvie $v$ Poludennuiu Rossiju [Travels to Southern Russia] (Moscow, 1802) I nave incorporated Izmailov's comments from part of a lenfthy quotation from his work prosented in Marakuev, Petr Simon Falias, pp. 22-23. 
to finish the piece of work that weighed on his mind as the only appropriate piece of work with which to close olit his career--his Zoographia Dasso-Asiatice. I'I health, the loss of much of his land in 1807, and the further disillusionment created by the death of his wife caused him to "sell for a song" his Crimean possessions and return in June 1810 to Berlin, which he had not seen for forty-three years. He was accompanied by his daughter, who had lived with her father since the death of her husband--a German-born officer in the Russian army killed at Austerlitz in 1805. According to his closest friend in Berlin during the last year of his life (Pallas died in September 1811) and his first biographer, Karl Rudolphi, Pallas lived a "cheerful and salm" life in Berlin surrounded by a sea of young scientific scholars eager to enrich their careers by chattirg wi.th the recognized master. 14

14 "Peter Simon Pallas. Ein biographischer Versuch," p. 62. This is perhaps the best place to annotate Rudolphi's biography of Palias. Notwithstanding some specific research that has been done on Pallas, all lifie-accounts of Pajllas that have followed Rudolphi's work (1812) are either directly or at secondhard based on it. As the man closest to Pallas when he died, Rudolphi was given immediate access to Pallas private papers (by Fallas' daughter) to write an exterded elilogy. It is disappointing in its length in view of the immediate access he had to at least, some of Fallas' papeis, but it nevorthelass sets dom the ruajor facts (in eulogy fashion) and the outline of Pajlas' life. Regarding Pallas career in Russia, Rudolphi presented almost nothing beyorla the barest (five-page) outline of Fallas' major expe.. dition and a chronological amotation to Pallas' major written work in St. Petersbung, which Rudolphi, however, knew very well. 


\section{A Note on Pallas' 200GRAPHIA ROSSO-ASIATICA}

Pallas' three-volume Zoographia Rosso-Asiatica represents the completion ardi oulnination of tile central area to which Pallas devoted his career. Since several references have already been made to it in that context without much comment having been added, it would be appropriate at the close of Pallas' career to nake a few historical comments about it. It was the piece of work on which Pallas intended to let rest his scientific laurels. He wanted it as a masterpiece of original scientific content. That he contemplated it for a long time is evident. Throughout his career in Russia it had been his habit to excuse himself from presenting his zoological material (on vertebrates) at length because he was saving it for a curnulative work of this kind. The Zoographia was the culmination of a quarter-century of firsthand observation and study of the zoology of the Russian Empire, which he spent a major part of the last fifteen years of his life in organizing and synthesizing. F. Keppen, the man who in 1895 completed the most thorough study and compilation of Pallas' works yet to be done, described it as "immortal," which, to be as brief as possible, accurately sums up the comments that others have written. Throughout the nineteenth century it remained the sole summary of all the vertebrates of Russia and in it was incorporated all the innovations that Pallas made to the study of zoology.

Iike other of his works, the Zoographia was conceived in grandiose fashion and ended up with less than a complete 
finish. The manuscript texts of all three volumes were completed and sent to St. Petersburg before Pallas returned to Berlin in 1810. The first volume was completsd as early as 1803. Publication, however, was to await the completion of numerous color plates which Pallas contemplated to include and for which he arranged in 1803 with his favorite illustrator, Christian Geissler in Jeipzig, to make. Geissler began the work, but never came close to finishing and seemed in no hurry to do so. What he had done remained in Leipzig. Publication went ahead due to the importance of the works volume I in 1809; volume II in 1811; volume III in 1814. This iirst edition was printed in only a very few copies and made available by the St. Petersburg Academ to only a select few. Without illustrations it was considert:d incomplete and was not an itom for sale or exchange. Palias also considered it incomplete and was saddened by the circumstance. When he returned to Berlin he pressed for the completion of the illustrations to his masterpiece, which he was not anxious to see published posthumously in its completed form. The illustrations never came and even the textual material was not entirely in print by 1811.

The Zoographia was not forgotten following Pallas' death. The st. Petersburg Academy continued to press for the illustrations from Leipzig, and when that failed, assigned their own artists to begin the work of iliustration from scratch. Still incomplete, however, the zoographia came out 
in its first public edition in 1826. Pallas got part of his eulogy from st. Petersburg in the appearance of this edition itseif and in the explasatury note which rent along with it.

La ténacité, avec laquelle le célèbre auteur de cet ouvrage, dont le texte a été imprimé aux fraix de l'Académie, s'eat obstiné a rouloir que les planches fussent gravées à Leipzic par Vir. Geissler, a qui il avait confié les dessins originaux, a été cause que ce travail, qui auroit pu être exécuté a beaucoup moins de fraix, en beaucoup moins de tems et tout aussi bien, par des Artistes de St. Fetersbourg, ron obstiant ies conditions onéreuses, auxqueiles I'Académie avait consenti par égard pour son Erand Naturaliste, se trouve encore loin de son accomplissement, ce qu'il faut attribuer à un concours de circonstances fatales, dont il servit, trop iong de faire ici I'énumération et qui ne permettent pas même à l'fcadémie l'engagenent formel de fournir les figures de sitôt. Cependant comme le nombre des Naturalistes, qui temoignent un impatient désir d'acquérir au moins le texte de la Zoographie de Pallas, augmente d'année en année I'Académie s'est determinée à le mettre en vente, afin de satisfaire ce désir si nature et si 15

Three years later, in 1829, the Academy sent Karl $\mathbf{E}$. von Baer to Berlin and Leipzig to make an investigation into the story and whereakouts of the oxiginal illustrations made by Geissler. Baer uncovered the incompleteness of Geissier's work and told the story of the "villain" behind the delay of Pallas' Zoographia. ${ }^{16}$ Baer was unable to purchase what

\section{5rom Baer, Berichte, p. 15.}

16 Baer's Berichte is a thorough account of Fallas' Zoographia and ahighiy complimentary appraisal of Fallas' soiertific significance. With Pallas" work in st. Petersburg, Baer wrote ( $p .1$ ), "the systematic study of natural history. which was formerly commanded entirelit from uppsala, now has received its greatest enrichment from St. Petersburg." 
plates Geissler had completed, but his recommendations led to a new edition of the Zoographia (1831) with some additions made by Baer hinseif. Finis was the last zaition to appear and is the most common. Illustrations to the text were not yet completed and were published later apart from the text. 


\section{SELECTED BIBLIOGRAPHY}

The bibliography is divided into three sections: (1) multi-volume reference works and source coliections; (2) general works, works pertaining to the Academy of Sciences, and works providing backgrourd material; and (3) works pertaining specificaliy to Pallas. General or background works from which oniy material pertaining to pallas has been used are included in the third section and the specific pages noted. Basicaily, the items listed below are those that have been cited in the notes or those that have not been specifically cited but have shaped in a principal way the direction this paper has taken. All excessively peripheral items that were consulted but not cited in the notes have been excluded. Some inaterial has been cited in the notes which is not included in the bibliography to avoid clutterirs the basic material with which I have worked with itens that were useful only in an isolated instance or items listed orly for purposes of adiling bibliogranhic depth to a voint. Articles and books are listed together and certain articles from the reference works that were thought to $b \in$ of indspendent importance in content have been extracted and j.isted separateiy. Brief annotations are proviced where clarification: of material has been deemed recessary.

\section{MuIti-Volume Reference Works and Source Collections}

Acta Academiae Scientiarum Inperial is Petropolitanae. 6 vols. in 12. This series was the Academy's official publication for the years 1777-1783. Contained in each issue ( 1 issue per 6 months) is a record of the Acatemy's principal affairs (in French) and papers cojtributed by the academicians (in French or Letin). Every major event in the life of the Acadeny occasioned a name change in its principal publication. With Princess Dashirova's accession to the position of Director in 1783, the Acta became Nora Acta Academiae seientiaruin Imperialis Petropolitanee (published in $15 \% 0.1 \mathrm{~s}$. for the years $1783-10037$ witn onj y a slight change in format. Thereafter, with the issulance of the new charter in 1303 , the name became Mincires de l'scademie Imperizle des Scjences de St. Pétersbours, Frior to the Acta the publication was known under two titles: initially as Commentarij Academiae Scientianam Innerialis Petropolitanae (published in 14 vois. For the years 3.726-1747), end, with the Academy's inst charter in 
1747, as Novi Commentarii Academiae Scientiarum Imperialis Petropolitanae (published in 20 vols. for the years 1747-1776). The occasion for changing the name of the publication to Acta was the Academy's celebration of its fiftieth anniversary in 1776. Only with Acta was a record of principal Academic affairs included along with the scientific treatises and Latin ceased to be the exclusive language used. Commentarii and Novi Commentarii have therefore not been used for this study, except to make some surface observations.

Annual Register. Iondon, one volume per annum from 1758. Each of the earlier volumes utilized contains an individual section relating developments in natural history.

Bolshaia Sovetskaia Fntsiklopediia [Large Soviet Encyclopedia]. 2nd eá. 50 vols. Vioscovi, 1949-1957.

Dictionary of Scientific Biosraphy. Editor in chief Charles C. Gillispie. 6 vols. New York: Charles Scribner's Sons, 1970-1972. Now complete only trirough entry "Hyrt1".

Entsik] opedicheskii Slovar [Encyclopedia]. Edited by F.A. Erockhaus and I.A. Efron. 41 vols. in $82 . \mathrm{St}$. Petersburg, 1894-1904.

Materialy dilia Istorii Imperatorskoi Akademij Nauk [Sources for the History of the Imperial Academy of Sciences]. Edited by M.I. Sukhomlinov. 10 vols. St. Petersburg, 1885-1900. An important collection of documents pertaining to the Academy during the years from 1725 to 1750.

Mezhov, V.I. Sibirskaia Bibliografiia [Siberian Bibliography]. 4 vols. St. Fetersburg, 1891-1892.

Novyi Entsiklopedicheskii Slovar [New Encyclopedia]. Edited by F.A. Brockhaus and I.A. Efron. 29 vols. St. Petersburg, 1911-1916. Publication ceased with entry "otto".

Protokoly Zasedanji Konferentsi.i Imperatorskoi Akademii Nauk $s 1725$ po 1803 goda. Also known under the title Eroces-Verbaux des Séances de l'Académie Impériale des Sciences depuis sa Foundation Jusad 1803.4 vols. Si. Petersburg, 1897-1911. A summary record of what transpired in all of the Academic meetings for the years incicated in the title. 
Russkii Biograficheskii Slovar [Russian Dictionary of Biographies]. 25 vols. St. Petersiourg, 1896-1918.

Sbornik Imperatorskago Russkago Istoricheskago Obshchestva [Collection of the Imperial Russian Fistorical Society]. 148 vols. St. Petersburg, 1867-1916. Not a major source with respect to the specific subjects dealt with in this thesis, but well worth going through for pertinent bits and pieces of information.

II. General and Background Material and Material Reiating to the Academy

Acadenty of Sciences of the U.S.S.R. The Pacific: Russian Scientific Investigations. New Yorks Greenwood Press, 1959.

Berg, I.S, Ocherki po Istorii Russkikh Geograficheskikh Otkrytii loutlines of the History of Russian Geographical Discoveriés]. 2nd ed. Moscow: Akademila Nauk SSSR, 1949.

Bolikhovitinov, N.N, Stanovlenie Russko-Amerikanskikh Otnoshenii, 1775-1815 LThe Beginnings of RussianAmerican Relations, 1775-1815]. Moscow: "Nauka", 1966.

Clarke, Edward D. Travels to Russia, Tartary, and Turkey. Reprint ed. New York: Amo Press, 19?0. Reprinted Irom part I of Clarke's Travels in Various Countries of Furope, Asia, and Africa (Philadelphia, 1811).

Coxe, William. Account of the Russian Discoveries ketween Asia and America. Reprint ed. Ann Arbor: University Microfilms, 1966. Reprinted from the 2nd Iondon edition of 1780 .

- Travels into Foland, Russia, Sweden, and Denmark. Vol. III. Reprint ed. New York Arro Press, 1970. Raprinted from the 5 th London edition of 1802 .

D'Auteroche, Chappe. A journey into Siberia. Reprint ed. New York: Amo Press, 1970. Reprinted from the original English adition (Iondon, 1770 ).

"Direktor Akademii Nauk Kniaginia Ekaterina Romanovna Dashkova. Doklady Gosudaryne Inparatritse Elaterine vioroi [Director of the Academy of Sciences Princess Catherine Romanovna Dashkova. Reports to Fer Majesty the Empress Catherine II]. " Chteniia v Imperatorskom Obshchestve Istorii..., LY (Jan.-March, 1867), sect. V, 9-53. 
"Direktor Akademii Nauk Sergei Gerasimovich Domashnev [Director of the Academy of Sciences Sergei Cerasimovich Domashnev]." Chteniia v Imperatorslom oushchestve Istorii IIX (oct..-Dec., 1866), sect. V, 134-184.

Pigurovskii, N.A., ed. Istoriia Estestvoznaniia v Rossi.i [History of Natural Science in Russia]. Vol. I, pt. I. Moscow: Akademiia Nauk SSSR, 1957.

Gnucheva, V.F., ed. Materialv dlia Istorii Ekspeditsii Akademii Nauk $v$ XVIII i XIX Vekakh: Khronologicheskie Obzory i Opysanie Arkhivnikn ilaterialov LSources for the History of Expeditions of the Academy of Sciences in the 18th and 19th Centuries: Chronological Surveys and a Description of Archival Materials]. MoscowIeningrad: Akademiia Nauk SSSR, 1940.

Grekov, V.I. Ocherki iz Istorii Russkikh Geograficheskikh Issledovanii v $1725-1765 \mathrm{gg}$. Lutlines from the History of Russian Geographical Explorations in the Years 1725-1765]. Moscow: Akademiia Nauk SSSR, 1960.

Iablokov, V.S., and Plotkin, I.A. 220 Let Akademii Nauk [220 Years of the Academy of Sciences]. MoscowLeningrad: Akademiia Nauk SSSR, 194.5.

Kniazev, G.A., and Koltsov, A.V. Kratkii Ocherk Istorii Akademi i Nauk SSSR [A Short Outline of the History of the Academy of Sciences of the USSR]. 3rd ed. MoscowLeningrad: "Nauka", 196/.

Krasheninnikov, Stepan F. Explorations of Kamchatka. 1735 1741. Translated and edited with an Introduction by E.A.P. Crownhart-Vaughan. Portland: Oregon Historieal Society, 1.972 .

Kuznetsov, B.G. Ocherki Istorii Russkoi Nauki [Outines of the History of Russian Science]. Moscow-Leningrad: Akademiia Nauk SSSR, 1940.

Kuznetsov, I.V., ed. Liudi Russkoi Naluki: Ocherki o Vydajushchikhsia Deiateliakh Estestroznaniia i Tekrnikj. [Wer: of Russian Scierce: Essays on the Eminent Figures of Natural Science and Engineering], 4 vols. Moscow: "Nauka", 1961-1965.

Lauridsen, Peter. Vitus Bering. Translated from the Danish by Julius E. Olsor. Chicago S.C. Griggs and Co., 1889 .

Lazarev, P.P. Dcherki Istorii Russkoi Navki [outlines of the History of Russian Science]. Moscow-Leningrad: Akademiia Nauk SSSR, 1950. 
Locy, William A. Biology and Its Makers. 3rd ed. New York: Henry Holt and Co., 1935.

The Memoirs of Princess Dashkov. Translated and edited by Kyril Fitzlyon. London: John Calder, 1950.

Modzalevskii. B.I. "Akadeniia Nauk, Imperatorskaia Sanktpeterburgskaia [Academy of Scierces, The Imperial Si. Petersburg]:" Novyi Entsiklopedicheskii Slovar. I (1911), 638-660.

Spisok Chlenov Imperatorskoi Akademil Nauk, $1725-1907$ LA List of the Members of the Imperial Academy of Sciences]. St. Petersburg: Akademiia Nauk, 1908. A very useful reference work which includes a chronological listing, with annotations of basic factual data, of all members (regular, honorary, and corresponding) and officials of the Academy. The same type of listing is also provided for the Imperial Russian Academy.

Nordenskiold, Erik. The History of Biology. Translated from the Swedish by Leonard Bucknall Eyre. New York: Tudor Publishing Co., 1949.

Olby, R.C., ed. Late Eighteenth Century European Scientists. oxford: Pergamon Press, 1966.

Ostrovitianov, K.V., ed. Istoriia Akademii Nauk SSSR [History of the Academy of Sciences of the USSR]. VOI. I. Moscow-Leningrad: Akademiia Nauk SSSR, 1958. Basic Soviet survey of the Academy.

Pasquier, I. Gustave du. Léonard Euler et ses Amis. Paris: Ijibrairie Scientifique J. Hermann, 1927.

Pekarskii, P.P. Istoriia Imperatorskoi Akademii Nauk [History of the Imperial Academy of Sciences 2 vols. St, Petersburg: Akademiia Nauk, 1870-1873. The best single secondary source of information on the Academy and its principal members for the first forty years of its existence.

Sauer, Martin. An Account of a Geographical and Astronomical Expedition to the Northern Parts of Russia.. in the Years 1285-1224. London: Cadell and Davies, 1802.

Singer, Charles. A History of Biology. Rev, ed. New York: Henry Schuman, 1950 .

Smith, Sir James E., ed. A Selection of the Correspondence of Linnaeus and other Naturalists. 2 vols. IJondon: Paternoster Row, 182i. 
Stejneger, Leonhard. Georg Wilhelm Steller. Cambridge, Mass.: Harvard University Press, 1936.

Sukhomlinov, M.I. "Piatidesiatiletnii i Stoletnii Iubilei S.-Peterburgskoi skademii Nauk [The Fiftieth and Centennial Anniversaries of the St. Petersburg Academy of Sciences]." Russkaia Starine, VIII (1877), 1-20.

Tooke, William. View of the Russian Empire. Vol. I. Reprint ed. New Yorks Arno Press, 1970. Reprinted from the Iondon edition of 1800 .

Veselovskii, K.S. "Borba Akademikov s Direktorom S.G. Domashnevym [The Academicians" Struggle with Director S.G. Domashnev]." Russkaia Starina, JXXXVII (1096), 457-492.

"Otnosheniia Imperatora Pavla I k Akademii Nauk [Attitudes of Emperor Paul I Toward the Academy of Sciences]." Russkaia Starina, XCIV (1898), 5-18, 225-246.

"Poslednie Gody Proshlago Stoletiia v Akademii Nauk [The Latter Years of the Past Century in the Academy of Sciences]." Russkaia Starina, XCIII (1898), $225-245$.

Viatkin, M.P., ed. Ocherki Istori.i Leningrada [Cutlines of the History of Leningrad]. Vol. I. Moscow-ieningrad: Akademiia Nauk SSSR, 1955.

Vucinich, Alexander. Science in Russian CuIture. A History to 1860. Stanford: Stanford University Press, 1963. This excellent work has been a valuable aid in both textual and bibliographic material.

Watrous, Stephen D. John Ledyard's Joumey Through Russia and Siberia, 1787-1788: The Journal and Selected Letters. Madison: University of Wisconsin Fress, 1966.

Wolf, A. A History of Science, rechnology, and Philosophy in the Eighteenth Con tury. 2nd ed. London: George AIlen and Unwin, 1952 .

Zittel, Karl Alfred von. History of Geoloev and Falaeontology. Translated from the German by haria. M, Ogilvie-Gordon. Iondon: Walter Scott, 1901.

Zubov, V.P. Istoriografiia Estestvennyk v Rossii (XVIII v.pervaja oplovina $X I X$ V.) [Historiography of the Naturaj. Sciences in Russja (18th and first half of 19 th Centuries)]. Moscow: Akademiia Nauk SSSR, 1956. 
III. Material Specifically Related to Pallas

Baer, K.E. von. Berichte über die Zoographia Rosso-Asiatica von Pallas, Königsberg, 1831.

Baranskii, N.N., et. al., eds. Otechestvennye FizikoGeografy i Puteshestvennikj. LPhysical Geographers and Travelers of Russia]. Moscow: Izdatelstvo Ministerstva Prosveshcheniia RSFSR, 1959. On Pallas, pp. 132-145.

Belousov, V.V. "P.S. Pallas--Puteshestvennik i Geolog (is 200-letilus goda rozhdeniia) [P.S. Pallas--Traveler and Geologist (commemorating the 200th anniversary of his birth)]." Priroda, no. 3 (1941), 111-116.

Carus, J. Victor. Geschichte der Zoologie bis auf Joh. Müller und Charl. Darwin. Niunich: R. Oläenbourg. 1872. On Pallas, pp. 535-539.

Cuvier, Georges. "Éloge Historique de Pjerre-Simon Pallas, Iu le 5 Janvier 1813." In his Recueil des Eloses Historiques lus dans les séances publiques de l'Institut Royal de France. Vol. II. Paris, 1819, pp. 109-156.

Dementev, G.P. "Pallas ( $k$ stopiatidesiatiletiiu so dnia smerti) [Pallas (commenorating the 150th anniversary of his death)]." Zoologicheskii Zhumal, XIII, no. 2 $(1.964), 262-271$.

Fradkin, N.G. "Instruktsiia dlia Akademicheskikn Ekspeditsii 1768-1774 g. . [The instructions for the f.cadernic Expeditions of 1768-1774]." Voprosy Geografii. XVII (1950), 213-218.

Kanaev, I.I. "O Faleontologicheskikh Rabotakh F.S. Pallasa ion the Paleontological Works of P.S. Palias]." Voprosy Istorii Estestvoznaniia i Teknniki, XIII (1962), $146-148$.

Keppen, F. "Petr-Simon Palias." Russkii Biograficheskii Slovar, XIII (1902), 153-162.

"Uchenye Trudy P.S. Pailasa [The Scientific Works of P.S. Pallas]." Zhurnal Ministerstva Narodnago Prosveshcheniia, CCXCVIII (1895), sect, II, 386-43?.

Khabakov, A.V. Ocherki po Igtori i Geologo-Razvedochnykh Znanii v Rossii [Esiays on the History of Geological and Exploratory fecomplishments in Russia]. Moscow: Izdatelstvo Moskovskogo Ooshchestva Ispytatelei Prirody, 1950. On Pallas, pp. 176-192. 
Kirichenko, L.S. "Ocherki iz Istorii Veterinamoi Gelmintologii Dorevoliutsionnogo Vremeni. PetrSimon Pallas [Essays from the History of PreRevolutionary Veterinary Helminthology. Peter Simon Pallas]." Trudy Vsesoiuznogo Instituta Gelmintologii. $X V$ (1969), $147-151$.

Lignau, N.G. "Pallas kak Zoolog [Pallas as a Zoologist]." Zapiski Novorossiiskago Obshchestva Estestvoispytatelei. XII $(1916), 19-34$.

** I,iutkevich, E. "Pamiati Petra Simona Pallasa [Menory of Peter Simon Pallas]." Zapiski Novorossi.iskago Obshchestva Estestvoispytatelei, XII (1916), 1-17.

Marakuev, V. Petr Simon Pallas, Ego Zhizn, Uchenye Trudy i Puteshestviia [Peter Simon Pallas, His Life, Scientific Works and Travels]. Moscow: A.A. Torletskii, 1877.

* Markevich, A.I. "Akademik P.S. Pallas, Ego Zhizn, Prebyvanie $v$ Krymu i Uchenye Trudy [Academician P.S. Pallas, His Life, Residence in the Crimea and Scientific Works]." Izvestila Tavricheskoi Uchenoi Arkhimoi Komissii, XIVII (1912), 167-242.

Masterson, James R., and Brover, Helen. "Bering's Successors, 1745-1780. Contributions of Peter Simon Pallas to the History of Russian Exploration Toward Alaska." Pacific Northwest Quarteriy, XXXVIII, no. 1 (jan., 1947), 35-83; XXXVIII, no. 2 (Apr., 1947), 109-155. Also in book form (Seattle, 1948).

* Okrokvertskhova, I.A. Puteshestvie Pallasa po Rossii [Pallas' Trave 1 s in Russia]. Saratov: Izdatelstvo Saratovskogo Universiteta, 1962 .

Fallas, P.S. "Memoire sur la Variation des Animaux." Acta Academiae Scientiarum Imperialis Petrodolitanae, IV. pt. II (1780), sect. I, 69-102.

- "Observations sur la Formation des Montagnes et Jes Changemens arrivés au Globe, particulierement a l'égard de I'Empire de Russie." Acta Academiae Scjent:arum Imperialis Petropolitanae. I, pt. I (17??). sect. I, 21-64.

- Travels through the southern Provinces of the Russian Empire in the Years 1793 and 1794.2 vols. mranslated from the German by Fransis W. Blagdon. London: Longman and Rees, 1802-1803. 
Voyages de M. P.S. Pallas, en Différentes Provinces $d \epsilon{ }^{\prime}$ 'Empire de Russie, et dans L'Asie Septentrionale. 5 vols. Translated from the German by M. Gauthier de la Peyronie. Paris, 1789-1793.

Raikov, B.E. Russkie Biclogi-Evoliutsionisty do Darvina. Materialy $\mathrm{k}$ Istorii Evoliutsjonnoi Idei v Rossij LRussian Evolutionary Biologists to Darwin. Essays Pertaining to the History of Evolutionary Thought in Russia]. Vol. I. Mosccw-Ieningrad: Akademiia Nauk SSSR. 1952. on Pallas, pp. 42-105. Bibliography to this section also useful, pp. 450-452.

Ratzel, Friedrich. "Peter Simon Pallas," Allgemeine Deutsche Biographie, XXV (1887), 81-98.

Rudolphi, D. Karl Asmund. "Peter Simon Pallas. Ein biographischer Versuch." In his Beyträge zur Anthropologie und allgeme inen Naturgeschichte. Berlin: Haude und Spener, 1812, pp. 1-78.

Sherborn, C.D. "The New Species of Birds in Vroeg's Catalcgue, 1764." Smithsonian Miscellaneous Collections, XIVII (1905), 332-341. Companion article innediately following: Richmond, C.W. "Notes on the Birds Described by Pallas in the "Adumbratiuncula. of Vroeg's Catalogue," 342-347.

"On the Dates of Pallas's 'Zoographia RossoAsiatica'." The Ibis, IV, no. 1 (Jan., 1934), 164-16?.

Snith, C.H. "Memoir of Pallas." The Naturalist's Library. Vol. IX. Edited by Sir William Jardine. Edinburgh: W.H. Lizars, 1839, pp.-17-76.

Sontsov, A.A. "Fallas v Krymu [Pallas in the Crimea]," Drevniaia i Novaia Rossiia, I, no. $3(1876), 279-289$.

St. John, James Augustus. The Lives of Celebrated Travellers. Vol. III. New York: Harper and Brothers, 1859. on Pallas, pp. 65-98.

Urress, Carol, ed. A Naturalist in Russia: Letters from Feter Simon paljas to Thomas Perriant. Minneapolis: University of Minnesota Press, 1967.

Winter, I., ed. Iomonosov, Schlözer, Pallas. Vol. XII of Quellen und Studien zur Geschichte Osteuropas. Berlin, 1962. On pallas, pp. 245-317. Section made up of nine individual articles. Those used are cited individually in the notes. 
**\#elenetskii, N.M. "Petr Simon Pallas, Ego Zhizn, Nauchnaia Deiatelnost i Rol v Izuchenii Rastitelnosti Rossii [Peter Simon Pallas, His Life, Scientific Work and Role in the Study of the Vegetation (Fiora) of Russia]." Zapiski Novorossiiskago Oushchestva Estestvoispytateiei, XII $(1916), 35-104$.

* I have not gained access to these two items, but have included them to add to the completeness of works relating specifically to Pallas of which I have an awareness. The bibliographic data has been double-checked in several sources. okrokvertskhova's work is listed as being 75 pages in length.

** These works, all from the same issue of the same journal, were speeches delivered before the Society of Natural Scientists in Odessa on October $29(0.5), 1911$. The occasion was a ceremonial session of that body dedicated to the memory of Pallas and the speeches constituted the sum of the proceedings. All three were later prepared specifically for publication and all have merit as informative works on Pallas. Zelenetskii's article deserves special mention, however, because it was considerably expanded as a result of extensive research in the Academy archives. It is limited principally to Pallas botanical contributions, but in that respect has fully illuminated the vast amount of work done by Pallas in that area. A great deal of bibliographic material is included which considerably expands upon Kerpen's list of Pallas botanical work and all listings are complete with full, sometimes very extensive, arnotations. 


\section{APPENDIX}

IIST OF RUSSIAN-SPONSORED SCIENTIFTC

EXPEDITJONS IN THE EIGHTEENTH CENTURY ${ }^{1}$

Main Participant or Title

1. Gottlieb Schober

2. Karl von Verden \& Fedor Soimonov

3. Daniel Messerschmidt

4. Jchann Buxbaum

5. Johenn Buxbaum

6. Johann Gerber

7. Louis Delisle de la Croyère

8. First Bering Expedition

9. Great Northern Expedition

10. Johann Lerche

1i. I.K. Kirilov

12. Johann Heinzelmann
Years

$1717-20$

$1719-21$

1720-27

1721-24

$1724-26$

1722-29

$1727-30$

$1725-30$

$1732-43$

1733-35

$1735-37$

$1734-37$
General Area

Lower Volga;

Caucasus

Caspian

Siberia

N.W. Europear

Russia

Constartinople;

Caucasus

Caspian

N. European

Russia

Kamchatka;

N. Pacific

Siberia;

Kamchatka;

N. Pacific

Lower Volga;

Caucasus

S. Urais;

Central Asia

S. Urals;

Central Asia

$1_{\text {Tris }}$ listing is compiled principally from information presented in V.F. Gnucheva, ed. Materialy dlia Istori.i Ekspeditsii Akademii Neuk v XVIII i XTX Vekakh: Khrono]ogicheskie obzory i Ooysanie Arkhimiki Materialov (Moscow-Leningrad, 1940). 
13. Traugott Gerber

14. Joseph Delisle

15. Johann Lerche

16. Christian Kratzenstein

17. Mikhail Kovrin

18. Stepan Krasheninnikov

19. Augustine Grischow

20. Franz Elachich

21. Andrian Dubrovskii

22. Andrei Grekov

23. Nikita Popov \& Stepan Rumorskii

24. Johanin Lehmann

25. Erik Laxmann

26. A.N. Svechin
$1739-41$

1740

$1745-47$

$1751-53$

1751

1752

$1752-57$

1753

1759-61

1761

$1761-62$

1764

1764-69;

$1784-96$

1.765

$1768-74$

1769-72

1768-73

$1768-74$
S. European

Russia; Volga

Berezov

Caucasus;

Persia

N.W. European

Russia

European Russia

N.W. European

Russia

Baltic

China

Eujopean Russia

Medieval Russian Cities

Siberia.

S. Russia

Siberia

E. European

Russia.

S.E. European Russia; Urals; Siberia

S. Urals; S.E. European Russia

تrrals; N. European Russia

Caucesus:

S. Russia 
31. Johann Güldenstädt

$1768-75$

32. Johann Falk

$1769-73$

33. Johann Georgi

34. Stepan Rumovskii

35. Ivan Islenev

36. Christopher Euler

37. Wolfgang Kraft

38. Georg Lowitz

39. Erik Laxmann

40. Gerhard Müller

41. Erik Laxmann

42. Peter Inokhodtsev

43. Vasilii Zuev

44. Franz Hermann

45. Fedor Chernoi

46. Nikolai Ozeretskovskii

47. Christopher Euler

48. Erik Laxmann

49. Peter Simon Pailas

50. Friedrich von Biberstein
$1772-74$

1769-70

$1768-73$

1768-71

1768-71

$1768-74$

1771

1778

1778-79

1781-85

1781-82

1784-96

1785

1785

1790

$1792-94$

$1793-94$

$1795-98$
Caucasus;

S. Russia

Urals; Siberia

Urals: Siberia

N. European

Russia

Siberia: S.W. European Russia

S. Urals (Orsk)

S. Urals

(Orenburg)

S.E. European

Russia

Holdavia;

Waliachiz

Moscow vicinity

N.W. Europesn

Russia

European Russia

Crimea;

Constantincple

Urals

Crimea

W. European

Russia

Finland

Tapan

S.E. Eurcpean

Russia; Caucasus;

Crimea

Crimea; Caucasus 


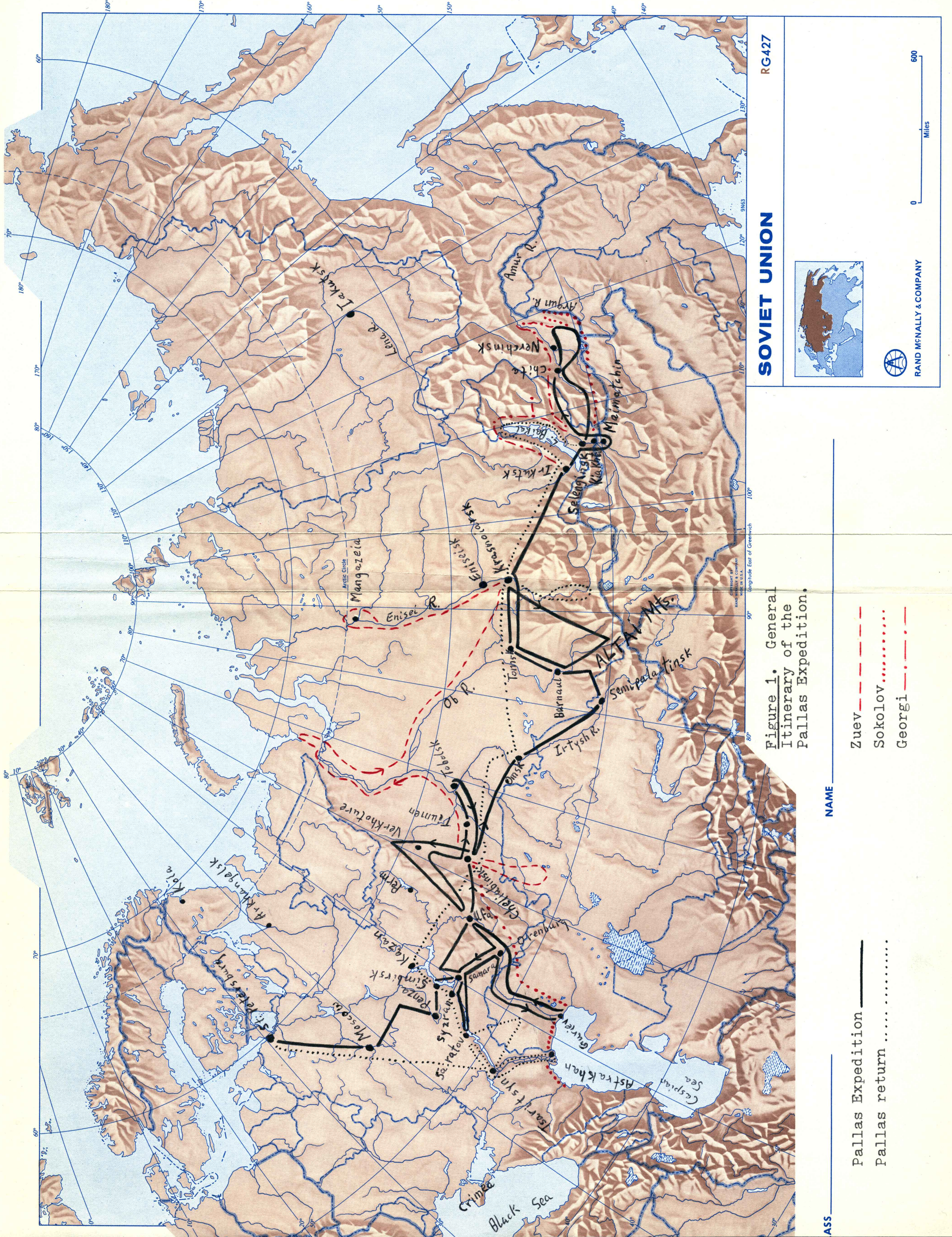

